Florida International University FIU Digital Commons

\title{
Relectura del discurso narrativo de las tres primeras décadas de la República cubana en el contexto de los rasgos de la picaresca
}

Gisela Bencomo

Florida International University

DOI: $10.25148 /$ etd.FI08081504

Follow this and additional works at: https://digitalcommons.fiu.edu/etd

\section{Recommended Citation}

Bencomo, Gisela, "Relectura del discurso narrativo de las tres primeras décadas de la República cubana en el contexto de los rasgos de la picaresca" (2003). FIU Electronic Theses and Dissertations. 131.

https://digitalcommons.fiu.edu/etd/131 


\section{FLORIDA INTERNATIONAL UNIVERSITY \\ Miami, Florida}

\section{RELECTURA DEL DISCURSO NARRATIVO DE LAS PRIMERAS TRES DÉCADAS DE LA REPÚBLICA CUBANA EN EL CONTEXTO DE LOS RASGOS DE LA PICARESCA}
A dissertation submitted in partial fulfillment of the requirements for the degree of DOCTOR OF PHILOSOPHY in
SPANISH
by

Gisela Bencomo

2003 
To: Dean Arthur W. Herriott

College of Arts and Sciences

This dissertation, written by Gisela Bencomo, and entitled Relectura del discurso narrativo de las primeras tres décadas de la República cubana en el contexto de los rasgos de la picaresca, having been approved in respect to style and intellectual content, is referred to you for judgment.

We have read this dissertation and recommend that it be approved.

$\begin{array}{r}\hline \text { Florence Yudin } \\ \hline \text { Santiago Juan-Navarro } \\ \hline \text { Reinaldo Sánchez, Major Professor }\end{array}$

Date of Defense: June 30, 2003

The dissertation of Gisela Bencomo is approved.

Dean Arthur W. Herriott

College of Arts and Sciences

Dean Douglas Wartzok

University Graduate School

Florida International University, 2003 
(C) Copyright 2003 by Gisela Bencomo

All rights reserved.

\section{DEDICATORIA}


Dedico esta tesis a mis padres, Luis y Mercedes, por su apoyo, sacrificio y paciencia durante todos estos años de estudio e investigación. A mis sobrinos, David y Javier Bencomo, con la esperanza de que cuando crezcan sepan valorar y amar nuestra historia y nuestra literatura. 


\section{AGRADECIMIENTOS}

Quiero expresar mi gratitud al Dr. Reinaldo Sánchez por iniciarme en los estudios de la literatura cubana y por su valiosa ayuda en el proceso de investigación y redacción de esta tesis; así como por enseñarme a pensar y escribir con claridad y guiarme y apoyarme incondicionalmente durante tantos años de estudio; pero, sobre todo, por haber sido un modelo a seguir, tanto en lo humano como en lo profesional. A la Dra. Florence Yudin por haber tenido la gentileza de ser parte de mi comité de tesis y por la valiosa ayuda que me brindó en la corrección del manuscrito. Al Dr. Santiago Juan-Navarro por darme la oportunidad de iniciar la investigación en sus cursos y por apoyarme y animarme durante todo el proyecto. A mi amiga de siempre, la Dra. Mercy Ares, por sus consejos y sugerencias en el transcurso de la investigación y escritura de esta tesis y, especialmente, por su aliento y apoyo incondicional de tantos años. A todos mis profesores y compañeros de clases cuyos consejos, conocimientos y experiencias han dejado una huella indeleble en mi formación personal y profesional. 


\author{
ABSTRACT OF THE DISSERTATION \\ RELECTURA DEL DISCURSO NARRATIVO DE LAS PRIMERAS TRES \\ DÉCADAS DE LA REPÚBLICA CUBANA \\ EN EL CONTEXTO DE LOS RASGOS DE LA PICARESCA
}

by

Gisela Bencomo

Florida International University, 2003

Miami, Florida

Professor Reinaldo Sánchez, Major Professor

The purpose of this dissertation was to study the narrative discourse of three Cuban novelists who produced their works from 1902 to 1933 , using a typology that reveals a picaresque view of Cuban society. Focusing on La conjura and La manigua sentimental by Jesús Castellanos (1879-1912), Las honradas and Las impuras by Miguel de Carrión (1875-1929), and Generales y doctores and Juan Criollo by Carlos Loveira (1882-1928), this dissertation identified and defined picaresque traits and elements in the characterization, contrasting main and secondary, male and female characters, at all social levels.

The study considered the theories of the Spanish picaresque novel proposed by Antonio Maravall, Américo Castro, Claudio Guillén, Marcel Bataillon, and other critics, in order to delineate a model of traditional picaresque behavior, which was then applied to the analysis of each 
character. Sociopolitical and cultural conditions, as well as the psychology of the Cuban collective as presented by the authors, were also analyzed to pinpoint similarities and differences between the traditional Golden Age rogue and the characters created by the authors.

Critics who have studied the influence of the Spanish picaresque genre on the Latin American novel make no reference to any of the authors or novels included in this study. Key analyses, however, identified the presence of characters that use picaresque modes of behavior as a means to manipulate the structures of power in order to survive and as a futile attempt to achieve their ends within a socioeconomic context that is undergoing a significant transition. Castellanos' characters use their picaresque behavior mainly to attain a higher social status. Carrión concentrates on picaresque behavior in women as a means to manipulate the dominant male society, while Loveira's picaresque characters are mainly interested in securing a position of political power. 
II. LA PICARESCA .6

1. La picaresca tradicional: Fundamentos teóricos y presupuestos críticos

2. Visión picaresca de la realidad. Picaresca social y picaresca literaria 15

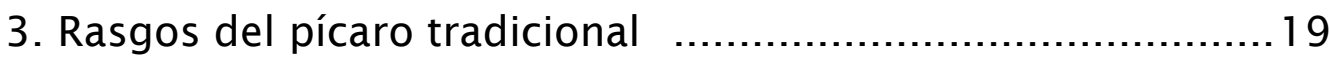

4. Las pícaras: rasgos distintivos f.....................................22

5. Influencia en España e Hispanoamérica ...........................25

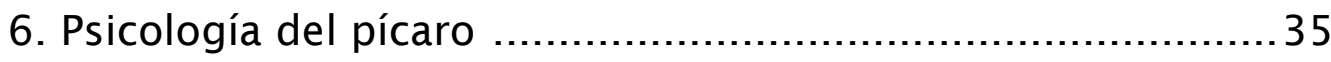

III. SOBRE CUBA Y LOS CUBANOS, 1902-1933 ............................38

1. El proceso histórico …..................................................40

A. De la conquista a la colonización ...............................40

B. Las luchas por la independencia ............................... 45

C. Los primeros pasos hacia la república ........................48

D. Los primeros treinta años de vida republicana ............51

2. Hacia la formación de la identidad nacional ......................60

A. Herencia étnica del pueblo cubano .........................61

B. Origen y formación de la nacionalidad cubana ...........68

C. Rasgos fundamentales de la psicología nacional .........71

D. Tipología de la sociedad cubana ................................ 80 


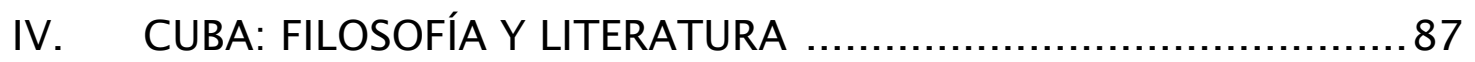

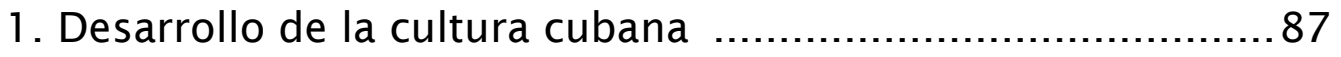

A. El pensamiento cubano ........................................ 92

2. Trayectoria del discurso narrativo cubano desde sus orígenes

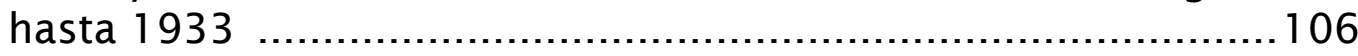

A. La prosa narrativa antes de 1902 ............................107

B. La primera generación republicana ............................115

V. PERSONAJES PICARESCOS EN LA NARRATIVA DE JESÚS CASTELLANOS …......................................................... 120

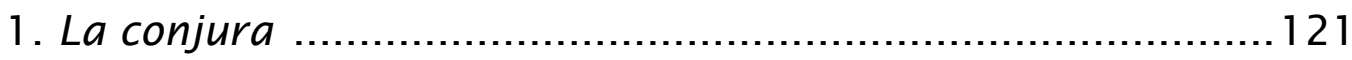

2. La manigua sentimental .................................................. 145

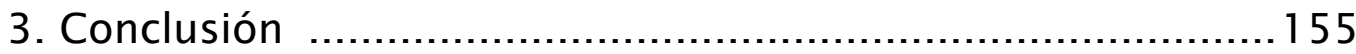

VI. PERSONAJES PICARESCOS EN LA NARRATIVA DE MIGUEL DE

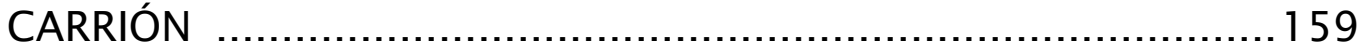

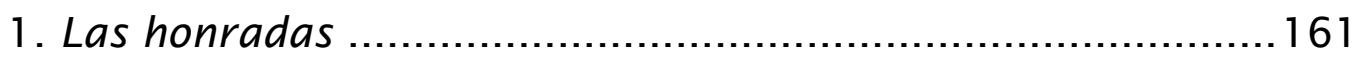

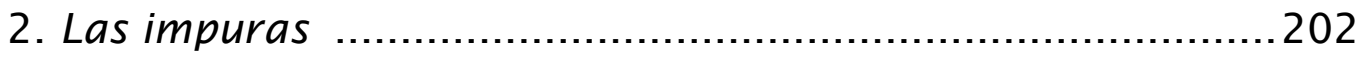

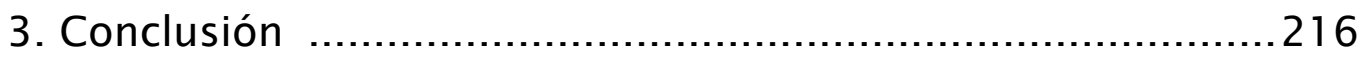

VII. PERSONAJES PICARESCOS EN LA NARRATIVA DE CARLOS

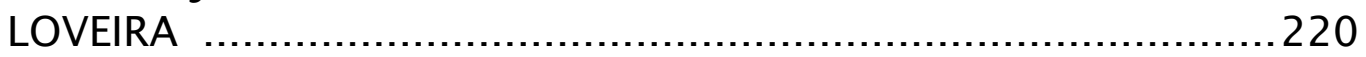

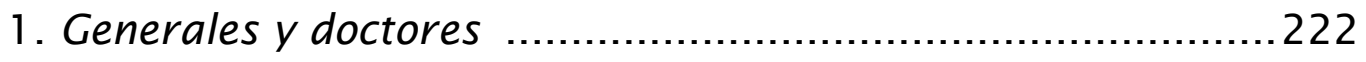

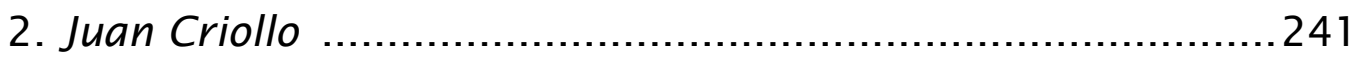

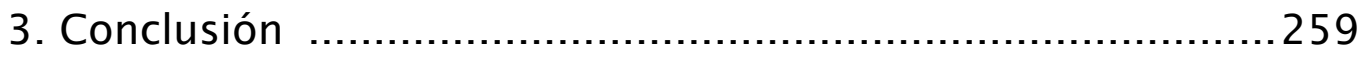

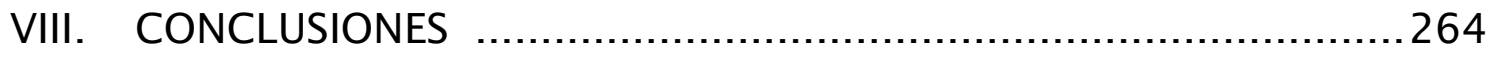




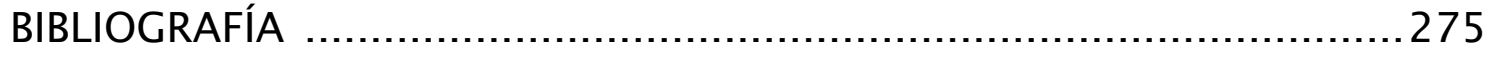

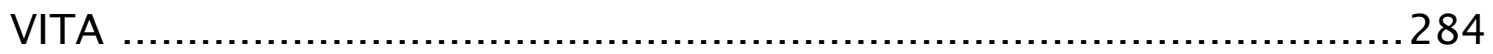




\section{Introducción}

La finalidad de esta tesis es realizar un estudio del discurso narrativo de tres escritores cubanos que surgen durante las tres primeras décadas de Cuba republicana (1902-1933), a partir de una tipología característicamente cubana en la que se descubren rasgos de una visión picaresca de la sociedad. El estudio se basa en la novelística de Jesús Castellanos (1879-1912), Miguel de Carrión (1875-1929) y Carlos Loveira (1882-1928). La obra de estos novelistas surge durante el momento de formación de la nacionalidad cubana y perfila un discurso propio para el estudio de muchos de los tipos de la naciente sociedad cubana, algunos de los cuales presentan rasgos del pícaro tradicional.

La investigación resulta de gran valor dentro del limitado corpus de estudios existentes sobre este discurso. Existen muy pocos trabajos sobre la literatura de esta época en general o sobre cada uno de los autores en particular. La mayoría da un enfoque crítico marxista o simplemente de evolución y desarrollo del autor y su obra. Un acercamiento a esta narrativa desde la perspectiva de la tipología que nos

presenta, no solamente resulta novedoso dentro del campo literario, sino que arroja luz en otros campos de estudio, como la sociología y la psicología de la sociedad cubana.

Al realizar la investigación se ha tenido en cuenta la bibliografía existente relacionada con los diferentes aspectos del tema. Para 
identificar los rasgos generales de la picaresca tradicional y delinear un modelo del comportamiento picaresco tradicional, se han utilizado los postulados críticos de José Antonio Maravall, Américo Castro, Claudio Guillén, Alexander Parker, y Marcel Bataillon, entre otros. La obra historiográfica sobre la literatura cubana de Raimundo Lazo y de Juan J. Remos ha sido la base para la contextualización de estos escritores dentro de un marco literario específico. Los trabajos de Calixto Masó, y de Carlos Márquez Sterling han sido de gran utilidad para hacer una revisión del marco histórico cubano de la época. El estudio de la psicología del cubano y los postulados filosóficos imperantes en la isla durante la época estudiada, se ha basado en las obras de Fernando Ortiz, Jorge Mañach, Raimundo Menocal y Calixto Masó, entre otros.

El primer capítulo está dedicado al estudio de las teorías sobre la picaresca en general. Se tienen en cuenta no sólo los estudios dedicados a la caracterización del género dentro del Renacimiento y el Barroco, sino también estudios más modernos, como el de María Casas de Faunce, donde se discute la influencia del género picaresco en textos posteriores, tanto españoles como latinoamericanos. Asímismo, se presenta un análisis del "pícaro" que sirve para redefinirlo dentro de los contextos cubanos de la época estudiada.

En el segundo capítulo se hace una revisión del marco histórico desde el momento del descubrimiento en 1492, hasta 1933 . Se toman en 
consideración las condiciones socio-políticas y culturales existentes en el momentos del surgimiento del corpus narrativo objeto de esta investigación y las influencias que pueden haber ejercido en el origen de toda una tipología de personajes. En este capítulo también se realiza un estudio de la psicología del cubano, tomando como base los diferentes elementos étnicos que contribuyeron a su formación y las características que cada grupo aportó al carácter nacional.

El tercer capítulo consiste en un estudio general de las principales corrientes del pensamiento filosófico cubano predominante en la época, entre las que se destacan las de Félix Varela, José de la Luz y Caballero, José Antonio Saco y Enrique José Varona. Se realiza también en este capítulo una panorámica de la narrativa cubana desde sus inicios hasta la época donde se sitúan las obras estudiadas.

El cuarto capítulo está dedicado al estudio de dos novelas de Jesús Castellanos: La conjura (1908) y La manigua sentimental (1909). Son éstas dos novelas cortas donde el autor combina la estética del modernismo con una aproximación crítica de la realidad histórica y social que lo rodea, y donde se desenvuelven personajes de corte picaresco que luchan por sobrevivir dentro de dicha realidad.

El quinto capítulo se concentra en el estudio de dos de las novelas más importantes de Miguel de Carrión: Las honradas (1918) y Las impuras (1919). Estas dos obras forman un díptico en el cual aparece la 
mujer con papel protagónico y como elemento que mueve todos los hilos de la historia; y en que lo femenino adquiere relevancia. Su obra es primordial para conseguir una visión picaresca desde la perspectiva femenina.

En el sexto capítulo se presenta el análisis de dos obras de Carlos Loveira: Generales y doctores (1920) y Juan Criollo (1928). En estas obras el autor se acerca a la problemática social cubana desde diferentes ángulos, especialmente los relacionados con la vida política republicana. En sus novelas Loveira caracteriza a personajes típicos de la vida política nacional cubana a través de prototipos que se circunscriben al modelo picaresco, con el propósito de retratar la opaca realidad cubana de su época a la vez que cumple con sus intenciones de llevar a cabo una labor de crítica social.

En resumen, esta tesis realiza un estudio de las obras de estos escritores tomando en cuenta, específicamente, la tipología que cada una de ellas presenta, con la intención de descubrir en ellos rasgos que se atribuyen al pícaro tradicional. Partiendo de los estudios críticos de Claudio Guillén, José Antonio Maravall, y María Casas de Faunce, entre otros, se teoriza sobre la picaresca tradicional. Se lleva a cabo un estudio de la historia de Cuba correspondiente al período de los textos estudiados, así como de las corrientes filosóficas imperantes y la psicología de la naciente nacionalidad cubana. La tesis en su totalidad es 
un trabajo que identifica y analiza características señaladas por la crítica como típicas del pícaro tradicional para redefinir la tipología cubana que se presenta en estas obras y que manifiesta modos de comportamiento picarescos en el contexto de una realidad política, económica y social que se halla atravesando un período de transición. 
Capítulo Primero. La picaresca.

La picaresca es un género clave dentro de la narrativa española del Siglo de Oro y a su vez, reflejo del momento histórico y de la realidad socioeconómica de España en el momento de su surgimiento. De acuerdo con algunos críticos, la obra iniciadora del género es la novela anónima La vida del Lazarillo de Tormes (Burgos, 1554), mientras que otros afirman que esta obra fue solamente precursora y que en realidad la picaresca fue iniciada con el Guzmán de Alfarache de Mateo Alemán (1599). No solamente los críticos no parecen ponerse de acuerdo en cuanto a cuál fue la primera obra picaresca, sino que tampoco hay unanimidad de criterios en cuanto a otros aspectos relacionados con el género.

Uno de los temas que resulta controvertido es el de las causas de su origen. La mayoría de los críticos son de la opinión que la picaresca surge en España, y en esos momentos, porque las condiciones sociales eran las propicias para la aparición de una delincuencia a gran escala. Algunos como Américo Castro y Alexander A. Parker, cuestionan los planteamientos anteriores y defienden otras posturas. Castro señala que la literatura picaresca es el resultado de un resentimiento social por parte de las clases bajas contra las clases más privilegiadas (121), mientras que Parker afirma que "[. . .] el problema es esencialmente de tipo histórico literario" (49). 
La definición del género picaresco y el establecimiento de sus características generales ha sido objetivo de estudio de numerosos hispanistas. En este aspecto hay también opiniones dispares y posiblemente la razón que justifica esta situación es el hecho de que cuando los autores comenzaron a escribir picaresca, no estaban conscientes de que se estaba creando un nuevo género literario. A posteriori, los críticos han ido estudiando diferentes obras, y encontrando en ellas una serie de características que se han deducido, pero que en su momento no fueron prescriptivas. Como consecuencia de esto, la variedad de opiniones sobre cuáles son los rasgos caracterizadores del género son numerosas. La falta de consenso en el señalamiento de las características del mismo tiene, a su vez, otra consecuencia: la disparidad de opiniones en cuanto a cuáles de las obras son picarescas y cuáles no lo son.

A pesar de todas las controversias antes señaladas, existe un elemento unificador, presente en todas las teorías y opiniones críticas: la existencia de un personaje protagónico, diferente en su esencia a todos los protagonistas de los géneros novelescos anteriores, y que posee unas características muy sui generis: el pícaro. La caracterización de este tipo de personaje también ha dado lugar a numerosos estudios en los que se le acreditan una serie de rasgos morales que ayudan a determinar una filosofía y una psicología del mismo. Algunos de los autores del Siglo de 
Oro introducen una variación en su protagonista, el cambio de sexo, y así aparece la pícara. Muchos de los estudios críticos se enfocan específicamente en el estudio de las obras con protagonista femenino y en el análisis de los rasgos caracterizadores de la pícara, algunos de los cuales comparte con su contrapartida masculina.

La novela picaresca española dio lugar a una serie de obras en Europa y Hispanoamérica. No solamente siguieron el ejemplo autores europeos contemporáneos con los del Siglo de Oro español, sino que la influencia de la picaresca puede trazarse, tanto en la novela española como en la hispanoamericana, hasta nuestros días. En muchos casos no puede hablarse de una obra picaresca en el sentido clásico del término, pero sí de la presencia de unos rasgos picarescos, ya sea en cuanto a su estructura o a la psicología de su protagonista. Con respecto a este aspecto hemos observado que, si bien muchos autores están de acuerdo en que la picaresca tuvo y sigue teniendo influencia en ciertos autores, casi todos los estudios giran alrededor de un número determinado de obras, donde fácilmente pueden rastrearse los rasgos de la novela picaresca clásica, según han sido postulados por especialistas como Claudio Guillén, Marcel Bataillon y Alexander A. Parker, entre otros. Sin embargo, hay que tener en cuenta que la psicología del pícaro va evolucionando y se va adaptando a las nuevas condiciones sociales e históricas de los diferentes escenarios en los que se mueve. 
1. La picaresca tradicional: Fundamentos teóricos y presupuestos críticos.

No es tarea fácil concretizar un concepto de la picaresca puesto que la misma se funda, como señalan Francisco J. Blasco Pascual y María del Carmen González Marín, "[ . . .] sobre una poética no formulada explícitamente [. . .]" (47), y esto dio lugar a que surgieran múltiples interpretaciones por parte de los autores de aquel momento. Fue así como la novela picaresca española sufre una evolución desde el siglo XVI al XVII y se advierten grandes diferencias entre el Lazarillo de Tormes y las obras posteriores, como las cervantinas, el Buscón o el Guzmán de Alfarache. Fue esa evolución la que ha dado lugar a que cada estudioso del género haya esbozado una posible definición del mismo, tomando en cuenta las características de las obras que son su objeto de estudio, y a veces dejando fuera otras que, no por no darse en todas las obras, son menos dignas de incluirse en una posible definición.

El término "novela picaresca" es, en realidad, una especie de etiqueta arbitraria y artificial que se le ha colocado a un grupo de obras que los estudiosos han clasificado retrospectivamente, tomando en cuenta unos elementos comunes bastante vagos. En la mayoría de los casos, los críticos dedicados a este género, se han acercado a las obras desde una sola perspectiva, es decir, tomando en cuenta solamente el tema, el contenido o la forma. Al plantearse la caracterización del género desde un solo punto de vista, se corre el peligro de eliminar ciertas obras 
que no cumplen con los elementos que el crítico considera primordiales al género, o de incluir en él a otras que solamente tienen un parecido tangencial con las obras picarescas. Un ejemplo de los antes planteado, es el caso de Angel Valbuena Pratt, que realizó un análisis temático e incluyó en el género picaresco obras tan dispares como El diablo cojuelo y la autobiografía, parcialmente real, de Diego Torres de Villarroel, titulada Vida y publicada en el siglo XVIII.

Otras opiniones críticas que intentan una definición de la novela picaresca se podrían dividir, básicamente, en dos grandes categorías. Un grupo basa su caracterización en la presencia de un tipo: el pícaro, y el marco social donde se desenvuelve el personaje. El otro, centra su análisis en la estructura de la narración. En el primer grupo, podemos situar a Alexander A. Parker y a Américo Castro. Para Alexander Parker, la característica distintiva del género la constituye el ambiente de la delincuencia. Si el protagonista llega a convertirse en un pícaro delincuente, entonces Parker considera que la obra pertenece al género picaresco. Esta posición lleva a Parker a afirmar que el Lazarillo de Tormes no es la primera novela picaresca, sino un precursor, por considerar que Lázaro no llega nunca a la categoría de delincuente (21). En el caso de Américo Castro, el elemento que parece ser de mayor importancia es que el autor del relato es posiblemente un converso que utiliza la obra para protestar contra la opresión social. 
Frente a estas posiciones que basan la categorización en el contenido, sin atender a los rasgos compositivos, se encuentra otro grupo que hace hincapié en la forma de la obra. Entre los críticos que adoptan esta postura crítica se encuentran Fernando Lázaro Carreter y Francisco Rico. Para ambos críticos la forma autobiográfica del relato es el rasgo distintivo más importante del género, seguido por la presencia de un personaje pícaro y el servicio, por parte de éste, a muchos amos. Por su parte, el crítico Walter Allen considera que el término "[. . .] picaresca se aplica a cualquier novela en la que el protagonista emprende un viaje en el curso del cual tropieza con hombres de toda suerte, clase y condición" (32).

En estudios más modernos encontramos visiones más eclécticas del género, como la de Antonio Rey Hazas, que afirma:

hay una poética característica de la novela picaresca que está configurada tanto por rasgos de estructura como de contenido, tanto por elementos formales como temáticos, que todos los novelistas metidos en sus filas adoptan en sus componentes básicos, aunque no necesariamente de la misma manera, puesto que, como en todo género literario, existen unos creadores y unos continuadores; $y$, entre estos últimos, unos se limitarán a repetir esquemas conocidos, 
mientras que otros intentarán cierta originalidad... dentro de la poética fundamental del género. (La novela picaresca 12)

De esta manera se advertirán dos niveles distintos en torno a la picaresca; el primero es en el que surgen unas determinadas características, y el segundo en el que muchas de las características se conjugan de formas diferentes, dando lugar a múltiples variaciones dentro del género.

A nuestro juicio, y como también opina María Casas de Faunce, ha sido Claudio Guillén quien mejor y más profundamente ha estudiado el género picaresco, y el que ofrece una visión más completa y abarcante de la poética señalada por Rey Hazas. María Casas de Faunce, basándose en el estudio de Claudio Guillén, titulado "Toward a Definition of Picaresque", define la novela picaresca como:

una narración ficticia, de cierta extensión y en prosa, expuesta desde el punto de vista de un ente acomodaticio cuya filosofía existencial, subjetiva y unilateral enfatiza el instinto primario del individuo que no ha desarrollado las funciones espirituales, ni la sensibilidad anticipada del hombre. (12)

Uno de los elementos que nos parece más novedoso de la caracterización llevada a cabo por Claudio Guillén es la subdivisión del género. Para Guillén, no existe una novela picaresca única, sino llega a la 
conclusión de que hay tres categorías: la novela picaresca en sentido estricto o clásica, la novela picaresca en sentido lato y lo que él llama "novela míticamente picaresca" (71). La ventaja que ofrece esta definición tripartita es que el estudioso puede estudiar una obra en particular, tomando como base los rasgos que se incluyen en cualquiera de las diferentes categorías, estableciendo una relación entre el género picaresco y muchas obras que no sería posible incluir si se consideraran unas definiciones del género más estrictas y estrechas. Se puede decir que el método de Guillén permite trazar una influencia del género picaresco en obras que por su estructura o por su origen literario, no son consideradas como tales. Por su parte, María Casas de Faunce extiende un poco más la visión de Guillén, y propone una categoría más, que es aquella en la que se pueden incluir novelas que contienen rasgos picarescos, aunque el autor no tuviera intención de escribir una novela picaresca en sí (13).

La novela picaresca clásica es la novela que se inicia en la corriente del Siglo de Oro, con El Lazarillo de Tormes, y que se cierra con Estebanillo Conzález (1646). Incluye un grupo de obras europeas que siguen una serie de características definidas, con algunas variaciones. Las características que señala Guillén como comunes a todos esos trabajos son: presencia de un protagonista pícaro, relato pseudoautobiográfico, visión parcializada y prejuiciada de la realidad, tono reflexivo, filosófico y 
crítico en cuanto a la moral y la religión, énfasis en el aspecto materialista de la realidad, observación, por parte del pícaro, de las diferentes clases sociales, movimiento del protagonista horizontal en el espacio y ascendiente en la sociedad, y relato episódico y de una aparente falta de composición (75-85).

En la novela picaresca en sentido lato se encuentran algunas de las características antes señaladas, pero transformadas, y se conservan algunos rasgos indispensables. Guillén considera indispensable "[. . .] the radical solitude of the orphan as a child or young man; and his lasting but ambiguous estrangement from society, 'reality,' or established beliefs and ideologies" (95). El elemento más importante de este tipo de obra es una filosofía de vida picaresca que se refleja en el modo de vida del protagonista y en la relación existente entre el personaje y el ambiente que lo rodea.

El establecimiento de la categoría "novela picaresca en el sentido mítico" se basa en el concepto del término "mito" como una tradición o historia cultural. Es decir, en una novela míticamente picaresca el lector puede reconocer rasgos de la tradición picaresca, por haberlos ya visto repetidamente en diferentes obras de este tipo. En estas novelas prevalece la figura del pícaro, pero las condiciones sociales, económicas y morales se transforman de acuerdo con la época o la situación geográfica donde se origina cada obra. 
Las teorías postuladas por Claudio Guillén han dado lugar a una tendencia, especialmente dentro de la crítica anglosajona, a estudiar la picaresca como un modo, es decir como uno de los muchos tipos de ficciones que pueden encontrarse dentro del desarrollo de la novela. Uno de los estudios más profundos sobre este tema es el del crítico Ulrich Wicks quien plantea que es necesario un reajuste en la visión del género picaresco para poder conciliar dos tendencias: una, que considera la picaresca como un género totalmente cerrado y donde solamente se incluyen las novelas españolas escritas en los siglos XVI y XVII; y la otra, que ve la picaresca como una tradición literaria abierta que puede encontrarse en cualquier obra. Este "modo picaresco" estaría caracterizado por un protagonista antihéroe que se encuentra atrapado en un mundo caótico, donde trata de sobrevivir y mejorar su categoría, siendo a la vez víctima y victimario del mismo ("The Nature" 240-242).

2. Visión picaresca de la realidad. Picaresca social y picaresca literaria.

Las teorías propuestas por los críticos para justificar la aparición de la novela picaresca en España abarcan numerosas perspectivas. Algunos críticos han tratado de rastrear los antecedentes de la picaresca en obras tan antiguas como El asno de oro y otros argumentan que los antecedentes ya se ven en el Libro del Buen Amor (1330) o La Celestina (1499). Para estos estudiosos, la picaresca se origina a partir de unos elementos puramente literarios. Hay quien ha afirmado que la picaresca 
surge precisamente en España, porque es consecuencia del carácter realista nacional español. Sin embargo, parece existir una opinión bastante generalizada de que la novela picaresca española es la expresión de una actitud determinada por ciertas condiciones sociales, morales y económicas existentes en España en el momento de su surgimiento y no el resultado de unos antecedentes literarios. Esta opinión puede tener validez si consideramos que la novela picaresca surge en un momento de grandes cambios, consecuencia de múltiples factores, como son el descubrimiento de América y la emigración de conquistadores y colonos hacia esas tierras, la expulsión de los judíos y los moros y las continuas guerras en que se había visto involucrado el imperio español desde la época de Fernando el Católico hasta el reinado de Felipe II. Entre los cambios que más afectaron la sociedad española de la época, Fernando Carrillo señala: " [ . . .] el cambio del centro de gravedad que pasa del campo a la ciudad, el papel decisivo que juega el dinero, el nuevo tipo de relaciones entre la sociedad y la destrucción de las viejas formas sociales" (69). Todas estas condiciones producen un desencaje social que propicia la existencia de seres marginados, dando lugar a una vida picaresca. Esto justificaría, definitivamente, la abundante e importante producción literaria de la picaresca. Podemos también afirmar que es en la época del surgimiento de la picaresca cuando comienza a vislumbrarse el debilitamiento de la hegemonía española. Por 
eso es quizás, que la picaresca se vuelve más sombría en el siglo XVII, cuando se agudiza la decadencia del imperio español.

Es importante señalar que Europa estaba sufriendo una serie de cambios en su estructura social, ya que la caída del sistema feudal y el crecimiento en importancia de una nueva clase burguesa había traído como consecuencia un replanteamiento de los valores y los modelos que habían sido establecidos por la aristocracia. Es por eso que la filosofía picaresca, detrás de una aparente aceptación del orden establecido, se burla del honor, el linaje, el amor, la virtud, y otros mitos de la sociedad aristócrata medieval.

María Casas de Faunce afirma que " [. . . ] existen dos realidades picarescas: una de filiación literaria y otra de índole social" (10). Según ella, la picaresca social la conforman una serie de tipos vivos procedentes de una categoría social baja, ya sea económica o moral. Por su parte la picaresca literaria, plantea Casas de Faunce, no es más que una mera categoría estética que se basa en una filosofía picaresca de la vida y que eleva "[. . .] a sustancia de novela [. . .] los hechos del mundo moral" (Correa 256). De esta forma, el autor de la novela picaresca critica y satiriza la sociedad en que vive.

Por su parte, José Antonio Maravall en su estudio titulado La literatura picaresca desde la historia social plantea que la literatura picaresca tiene sus orígenes en una serie de factores económicos, 
políticos y sociales. Este crítico opina que la distribución desigual de las riquezas, en el momento en que empieza a surgir la burguesía, es lo que produce un crecimiento de la pordiosería y el desempleo. Es así como un proceso de cambio económico da lugar a la aparición y desarrollo de un género literario. A juicio de Maravall, las condiciones económicas que se dan en España con la caída del feudalismo y la aparición de una clase media burguesa, son las que hacen posible el desarrollo de la picaresca. La importancia que cobra el dinero y el aumento de movilidad social dan lugar a que surjan en la sociedad una serie de tipos que más tarde serían los protagonistas de las novelas picarescas: los pícaros. Los críticos Francisco J. Sánchez y Nicholas Spadaccini, en su estudio de la obra de Maravall, afirman que según esta perspectiva,

[. . . ] la literatura picaresca vendría a ser un testimonio de una situación de alta conflictividad y un exponente de primer orden de la crisis que atravesara la sociedad española a lo largo de su transición a una plena sociedad de clases y, por lo tanto, un índice de las profundas contradicciones sobre las que se asentaba la construcción del Estado Moderno. (8)

A su vez, Antonio Rey Hazas afirma que el género picaresco está estrechamente ligado a la problemática socio-moral del momento, y sostiene que 
[. . .] la novela picaresca [. . .] (es) [. . .] un género especialmente adecuado para el debate ideológico, cuya poética implícita obligaba... el tratamiento de una serie de temas sociales, políticos y morales de plena actualidad-influencia del linaje, concepto de la honra, relación honradinero, relación honra-herencia, relación honra-aspecto externo, posibilidad del cambio social, concepto de nobleza, justicia-injusticia social. ("Poética " 75)

\section{Rasgos del pícaro tradicional.}

El término "pícaro", utilizado para referirse al protagonista de una narración picaresca, aparece por primera vez en la novela Cuzmán de Alfarache. Su origen y etimología han sido discutidos e interpretados abundantemente. Rafael Salillas es de la opinión que el vocablo "pícaro" es derivado de "picar", y trata de justificarlo diciendo que en muchos casos se utilizaba la palabra para referirse a los ayudantes de cocina (57). Covarrubias, en cambio, afirma que "pícaro" se deriva de la palabra latina pica otorgándole el significado de "un ser miserable". Hay quien piensa que está relacionado con el término bigardo, que es sinónimo de vago y vicioso. Hoy, la teoría más aceptada es la que relaciona el término "pícaro" con el nombre geográfico Picardía y con su gentilicio picardo. Esto le daría a la palabra "pícaro" el significado de "soldado roto, sucio y aventurero de aquella región, famosa en las guerras de la época" (Lope 
Blanch 16). Más tarde, posiblemente, el término se hizo extensivo a otros personajes de baja categoría y de vida aventurera. La definición de este término ha sido ampliada en los tiempos modernos por la Real Academia Española, que llama al pícaro: bajo, ruin, doloso, falto de honra y vergüenza, chistoso, alegre, placentero y decidor. María Casas de Faunce agrega a la lista anterior algunos de los siguientes sinónimos: bellaco, granuja, tunante, taimado, canalla, rufián, zascandil, pillo, bribón, golfo, truhán, calavera y perdulario, (15) por sólo nombrar unos cuantos. Como bien recalca la crítica, la palabra " [. . . ] conserva su matiz peyorativo original aunque trasciende del ámbito social al moral" (16).

A través de los tiempos, el personaje del pícaro ha sido caracterizado de diferentes formas, algunas de ellas contradictorias. Para algunos no es más que un conformista cuyo único objetivo es conseguir la posesión de bienes materiales; para otros, es un rebelde que rechaza su sociedad y los valores tradicionales que la caracterizan, a la vez que se burla de la misma e imita los vicios que de ella critica. Hay quien piensa que es optimista, otros lo califican de pesimista.

El pícaro por definición es el protagonista de la obra de Mateo Alemán. El mismo, aunque basado en tipos de la época, es una creación literaria, un personaje novelesco al cual se le han atribuido, como señala Antonio Rey Hazas, las siguientes características: actitud antiheroica, encarnación del deshonor, afán de ascenso social y parodia del honor, 
genealogía vil, ley del hambre y del ingenio picaresco, la mendicidad como modo de vida, delincuencia, paso de la inocencia a la malicia ( $L a$ novela picaresca 20-31).

El pícaro es un personaje pragmático, sin ningún tipo de principios, que se las arregla para sobrevivir en una sociedad cuyos elementos constitutivos le obligan a engañar para poder lograr la supervivencia. No se enfrenta a la sociedad, sino que mediante la trampa, el subterfugio y el engaño, trata de sacar partido de las condiciones caóticas de esa misma sociedad. Una de las características que más señalan los críticos es su conformismo. Acepta el status quo como algo inalterable. No quiere cambiar el orden social, lo que quiere es cambiar su posición dentro de ese orden. Su única motivación es el deseo de "medrar" y para lograr este objetivo puede llegar a poner al mundo a la defensiva. Aunque no ofrece resistencia, sí adopta una posición proteica y desempeña diferentes papeles dentro del orden social. Precisamente es esta característica una de las que más destacan muchos de los hispanistas. Esta actitud proteica se revela, en muchas ocasiones, como inconstancia de su personalidad. Es jovial por naturaleza y muestra una comicidad que le sirve para cubrir su cobardía y su inferioridad. La burla es característica inherente a la personalidad picaresca. Desde una posición inferior en la sociedad, el pícaro se burla de las cosas que sabe que son inalcanzables para él, y con el engaño trata de lograr lo que le impide su falta de valor. 


\section{Las picaras: rasgos distintivos.}

Los pícaros son más numerosos que las pícaras, y la razón de esto puede ser que la novela picaresca surge en una sociedad patriarcal, donde las figuras literarias femeninas eran relegadas a un segundo término. La variante femenina del pícaro hace su aparición durante el período Barroco. Es a partir del año 1605 (fecha de publicación de $L a$ pícara Justina, de Francisco López de Úbeda) que las novelas picarescas comienzan a tener un protagonista femenino. Algunas otras novelas de la picaresca femenina son La niña de los embustes (1632) y La garduña de Sevilla (1642), ambas de Alonso Castillo Solórzano, y La hija de la Celestina (1612) de Alonso Jerónimo de Salas Barbadillo. Como puede observarse, todas estas figuras femeninas fueron creadas por hombres, de manera que se reconoce una voz masculina en el discurso que restringe la voz de la pícara, de la misma manera que la sociedad limita sus posibilidades de movimiento (Wicks, Picaresque Narrative 60)

Según opiniones generalizadas de la crítica, la picaresca femenina no es una variación o continuación de la picaresca clásica (con protagonista masculino), sino que la misma lleva una intención diferente, fundamento que lleva al crítico Peter Dunn a plantear que When the protagonist is a woman, the sense of conflict is no longer evident in the picaresque. The pursuit of a life as a roguery is not an alternative to starvation, but is an existence 
possessing its own attractions, and the picara is made attractive by her beauty, her wit and her ingenuity. There cannot be the same violence as when the central character is a man, so the burla becomes less physically cruel but more dependent on deception and falsehood. (115)

Al igual que su contrapartida masculina, la pícara posee una serie de rasgos que la caracterizan y que han ido evolucionando a través de los tiempos. J. A. van Praag ofrece algunos rasgos que considera típicos de la personalidad de la pícara:

Conoce la pícara, en mayor grado aún que su colega masculino, la imperiosa necesidad de tener buena apariencia. En apariencia vive recatada; quiere pasar por dama de alcurnia [. . .] se rodea de escuderos y dueñas de aspecto venerable [. . .]. El lenguaje en que se expresan las pícaras y el tono de su conversación son los de las damas de buen linaje [. . .]. Dispone la pícara, a más de su innata astucia, de belleza corporal que sabe poner a precio [. . .]. Mientras el pícaro, al compararlo con las figuras de la comedia, corresponde mucho más al criado (gracioso) que al galán, la pícara se diría que se aproxima más a la dama que a la criada. Es que el pícaro carece de refinamiento: no logra salir de un modo permanente de su categoría social, y cuando 
sale siempre se traiciona. La pícara, al contrario, se mueve casi siempre en un ambiente muy superior al suyo y se mueve con facilidad. (63-74)

Mientras que el pícaro hace uso de su ingenio y de la burla para lograr "el medro", la pícara utiliza sus dotes físicas e intelectuales.

Hay un contraste básico entre la pícara y su versión masculina, y es la que señala Ann Daghistany, sobre el hecho de que la pícara nunca se convierte en una sirvienta de muchos amos. Esto no era posible en la sociedad de la época, y le deja una sola posibilidad a una mujer de clase baja: conseguir un marido rico (57). Afirma la crítica que "[. . .] one of the most noticeable characteristics of the picara is the active role she takes in initiating most of her encounters with men" (53). Esto tiene como consecuencia otro rasgo diferencial entre ambos tipos protagónicos: la moral sexual. Mientras que el pícaro acepta las reglas establecidas por la sociedad, la pícara no vacila en ejercer la atracción erótica para lograr su objetivo: subir de clase social.

Antonio Rey Hazas señala una característica que es común a ambos tipos de personajes. Se refiere el crítico "[. . . ] al curioso mecanismo moral de los pícaros, que les impulsaba a excusar sus propias faltas y pecados acusando a los demás de ellas [. . .]", y plantea que el mismo "[. . .] se repite en las pícaras de modo semejante, sólo que significativamente, origina otro de sus rasgos distintivos: el 
antifeminismo" (Picaresca femenina 94). En opinión de Rey Hazas, las pícaras justifican su comportamiento de crueles, infieles, ingratas, traidoras y mentirosas con la excusa de que así son todas las mujeres (Picaresca femenina 94).

\section{Influencia en España e Hispanoamérica.}

Casi desde sus inicios, la picaresca española ejerció su influencia en escritores contemporáneos europeos. Esta influencia se fue extendiendo hasta llegar a escritores posteriores de gran talla, tanto en España como en Hispanoamérica; y puede afirmarse que sus efectos se prolongan hasta nuestros días, como lo demuestran los estudios hechos por numerosos hispanistas especialistas en el tema. No es nuestra intención presentar aquí una lista exhaustiva de autores en cuyas obras se encuentran rasgos de la picaresca clásica, pero si queremos señalar una serie de trabajos que han sido objeto de estudio a partir de una perspectiva picaresca y que nos ayudarán a trazar una trayectoria de la influencia que el género ha ejercido hasta la época contemporánea.

El crítico Manuel Durán afirma que "la supervivencia de la picaresca en la narrativa española del siglo XVIII [. . .] es más bien escasa, limitada, pobre" (73-74). Sin embargo, menciona dos obras que, a nuestro juicio, contienen elementos picarescos. Estas obras son la Vida de Torres Villarroel y Fray Gerundio de Campazas del Padre Isla. El mencionado crítico es de la opinión que dichos trabajos no "[. . . ] son suficientes para 
establecer una continuidad en la narrativa que podamos derivar de la gran tradición picaresca del Siglo de Oro [. . .]" (74), pero no puede negarse que hay en ellos una influencia de la misma. Otra obra a la cual Durán no le niega sus "ribetes picarescos" (74) es la de Ramón de la Cruz. Los sainetes de De la Cruz se acercan a la picaresca porque sus héroes tienen rasgos muy parecidos a los del pícaro. En la mayoría de los casos estos personajes son pobres, ignorados por la sociedad, y hasta cierto punto marginados. También el ambiente y las situaciones que se presentan en muchos de los sainetes tienen su veta picaresca.

En lo que se refiere al siglo XIX español, no se puede dejar de mencionar la influencia que la picaresca ejerció en el que muchos consideran el más importante autor de la época: Benito Pérez Galdós. Tanto Gustavo Correa como el propio Manuel Durán, han dedicado varios estudios a rastrear y discutir la presencia de elementos picarescos en la obra de dicho autor. A juicio de Correa, la obra novelística de Galdós representa una "[. . .] auténtica proyección de la picaresca en los tiempos modernos [. . .]" (720). Entre las novelas de Galdós a las que se les atribuyen rasgos picarescos encontramos La desheredada, El doctor Centeno, Lo prohibido, y una de sus obras maestras, Misericordia. El propio Galdós nos señala la influencia de la tradición picaresca del Siglo de Oro en sus obras, cuando al referirse al personaje protagónico de su novela El doctor Centeno dice: 
hay ciertamente, héroes más o menos talludos que, mirados con los ojos que sirven para ver las cosas usuales, se confunden con la primera mosca que pasa o con el silencioso, común e incoloro insectillo que a nadie molesta... Es un héroe más oscuro que las historias de sucesos que aún no se han derivado de la fermentación de los humanos propósitos. (1302)

En nuestra opinión, este tipo de personaje galdosiano tiene mucho de pícaro. En Misericordia, apunta Manuel Durán, " [. . .] la temática picaresca aparece a la vez plenamente desarrollada y trascendida por la caridad cristiana. Surge desde el principio el mundo pintoresco, inquieto y semi-subterráneo, de los mendigos madrileños [. . .]" (90). Otro elemento picaresco que se le señala a la obra galdosiana es el deseo de medrar sin trabajar por parte de varios de sus personajes, como Juanito Santa Cruz, de Fortunata y Jacinta.

En el siglo XX español, y dentro de la novela de la posguerra, no se puede hablar de la influencia picaresca sin referirse a Camilo José Cela. Como señala Gustavo Correa, Cela

[. . . ] establece una vinculación con el héroe de la picaresca en sus dos novelas Pascual Duarte (1942) y Nuevas andanzas y desventuras del Lazarillo de Tormes (1944). En la primera de ellas, el protagonista escribe sus confesiones en 
forma autobiográfica cuando se encuentra en la cárcel, a punto de ser ajusticiado por sus hazañas criminales. ("El héroe" 723)

En la narrativa hispanoamericana, la influencia de la picaresca aparece desde muy temprano, y como afirma Manuel Durán, es "[. . .] fácil trazar la influencia de este subgénero novelístico [. . .] (pues) [. . . ] basta aludir al Periquillo sarniento de Lizardi" (73). Es importante destacar, sin embargo, que las condiciones políticas, sociales y económicas en las que surgen nuestros pícaros no son las mismas que se dieron en España durante el Siglo de Oro. Por otra parte, de la misma manera que Maravall señala que el pícaro literario tiene su origen en un tipo que existía en la sociedad española de la época, podemos afirmar que con la llegada de los conquistadores al Nuevo Mundo, prolifera la presencia de pícaros en las sociedades de las colonias hispanoamericanas. Luis Leal advierte que la palabra "pícaro" no se encuentra en el Nuevo Mundo antes de 1598. Y comenta que es el poeta Mateo Rosas de Oquendo (cuya actitud picaresca ante la vida ha sido demostrada) quien primero la usa en su obra titulada Sátira a las cosas que pasan en el Pirú, año de 1598. Por su parte, Bernal Díaz del Castillo, en su Historia verdadera de la conquista de la Nueva España da testimonio de la presencia de personajes apicarados que llegaron a América formando parte de los ejércitos de Hernán Cortés y de Pánfilo de Narváez. Y señala Luis Leal que en dicha obra "se habla 
también de Maese Rodas, verdadero precursor del Periquillo de Lizardi en la práctica de la medicina sin conocimientos o licencia" (48). También hubo pícaros entre los indígenas, y de éstos nos habla Fray Bernardino de Sahagún, quien en su Historia general de las cosas de Nueva España, publicada en 1569, caracteriza al chocarrero, al rufián y otros tipos de comportamiento apicarado. Según Leal, "la conjunción de estos dos tipos, el español y el indio, dio origen a un pícaro criollo, el lépero [. . .]" (50).

También los pícaros literarios viajaron a América. Lugo y Lagartija, personajes de una pieza teatral cervantina, son los primeros. Más tarde será el quevedesco Don Pablos quien cruce el Atlántico. De esta manera, la picaresca continúa su trayectoria al otro lado del océano. Algunos contemporáneos de Oquendo, como Juan Rodríguez Freile, también demostraban una visión picaresca de la sociedad, como se hace evidente en su obra titulada El carnero (1 859), que contiene numerosos elementos picarescos, como apunta Luis Leal (53). Después de medio siglo aparecería otro pícaro: el protagonista de la obra de Carlos Sigüenza y Góngora Infortunios de Alonso Ramírez (1680). No es hasta bastante entrado el siglo XVIII que se publica en América otra obra de rasgos picarescos. Nos referimos a El Lazarillo de ciegos caminantes (1773) de Alonso Carrió de la Vandera. Así llegamos a la que se considera la primera novela hispanoamericana; "[. . . ]y sin duda, la primera novela 
picaresca de autor americano" (Leal 56): El Periquillo Sarniento (1816) de José Joaquín Fernández de Lizardi.

Luis Leal comenta que "la contribución de Fernández de Lizardi al género es la creación de prototipos picarescos originales: el lépero, el catrín, la pícara pomposa, el pelado, todos ellos genuinamente representativos de la nueva sociedad mexicana" (57). Por su parte, el novelista y crítico Agustín Yáñez al realizar un análisis de las diferencias entre estos tipos dice:

El pícaro reacciona con ingenio, muchas veces inmoral y anti-moral, no exento de hipocresía, para amoldarse a las circunstancias y poder vivir sin trabajos; el lépero --incapaz de nada noble, ni siquiera de los recursos ingeniosos del pícaro--reacciona con villanía y bajeza; y el pelado propiamente dicho reacciona sin otra malicia que su voluntad libertaria, su cansancio de postergación y su miseria orgullosa, no para insertarse o acomodarse en ajeno estilo de vida, como el pícaro o para desahogar su cloaca, como el lépero, sino para defender su género de existencia y su aspiración autonomista y autárquica. El pícaro es cobarde y mendaz; el lépero, alevoso y montonero; el pelado, valiente e individualista. (74) 
En el intento de comparar el Periquillo a sus congéneres españoles, no debemos olvidar que las circunstancias de su nacimiento son diferentes a las imperantes en España durante el Siglo de Oro. La época del Periquillo estuvo marcada por las ideas de Rousseau, y fue una "[. . .] época que comienza a ser cambiada por la nueva ciencia, por las nuevas ideas políticas en torno a la libertad, la igualdad y la fraternidad [. . .] que nos muestra una sociedad en decadencia, carcomida, fácil de hacerla rodar" (Leal 57). Al Periquillo Sarniento siguieron otras obras de corte picaresco del propio Fernández de Lizardi, y algunas de otros autores hispanoamericanos, como Divertidas aventuras del nieto de Juan Morera (Argentina, 1910) de Roberto Payró.

María Casas de Faunce, en su extenso estudio titulado La novela picaresca latinoamericana, siguiendo los postulados de Claudio Guillén mencionados anteriormente, realiza una clasificación de obras hispanoamericanas situándolas en una de las tres categorías señaladas por el crítico. Las obras a las que nos hemos referido en el párrafo anterior son consideradas por Casas de Faunce como "picaresca clásica". Dentro de la picaresca en sentido lato, es decir la, que "[. . .]mantiene los elementos constitutivos y la filosofía existencial de la picaresca [. . .] y que, a su vez, manifiesta el ingenio picaresco por medio de burlas" (101), la crítica menciona como ejemplos representativos las siguientes obras: El casamiento de Launcha (Argentina, 1906) de Roberto Payró, Suetónio 
Pimienta: Memorias de un diplomático de la República de la Zanahoria (Bolivia, 1924) de Gustavo Adolfo Navarro, Evaristo Buendía, Quince uñas y Casanova, aventureros (México, 1945) de Zamora Plowes y Tata Lobo (México, 1952) de Ermilo Abreu Gómez (101-102). En la última categoría, o sea, la novela "míticamente picaresca" y que, según la autora, "[. . .] se diferencia de las anteriores por su énfasis en lo social o costumbrista y porque el punto de vista narrativo no es el del pícaro, ni el de su picardía, sino el de un observador que ha interpretado subjetivamente la filosofía picaresca y la utiliza como medio expositivo de su ideología [ . . ]" (153154), encontramos, entre otros, los siguientes títulos: El cristiano errante (Guatemala, 1846-1847) e Historia del Perínclito Epaminondas del Cauca (1863), ambas de Antonio J. de Irizarry, El falso Inca (Argentina, 1905) y Chamijo (Argentina, 1930) de Roberto Payró y La vida inútil de Pito Pérez (México, 1938) de José Rubén Romero.

Algunos críticos, como Gustavo Correa, plantean que también se puede observar "un influjo directo de la novela picaresca en la novela hispanoamericana de los últimos años" (Correa, "El héroe" 725). Entre los ejemplos señalados por el crítico están el relato corto de Alejo Carpentier titulado El camino de Santiago (1967), la novela de Mario Vargas Llosa La ciudad y los perros (1963) y la novela titulada Cuía de pecadores (1972), del argentino Eduardo Gudiño Kieffer. 
Al tratar de rastrear la influencia de la picaresca del Siglo de Oro en nuestra literatura contemporánea, es imprescindible destacar, que el género ha sufrido una evolución. La misma es, mayormente, consecuencia de las circunstancias que se manifiestan en los diferentes escenarios donde surge la obra en particular. Sin embargo, a pesar de que las condiciones políticas, sociales y económicas son diferentes, se pueden encontrar en muchas de las obras de escritores contemporáneos constantes del género.

El estudio titulado "De Lazarillo a Eva Luna: Metamorfosis de la picaresca", de Peter G. Earle, contiene interesantes planteamientos sobre las características picarescas que aparecen en varias obras de la literatura hispanoamericana que no pertenecen al género picaresco que Guillén llama clásico. Son obras que sin ser clásicamente picaresca, presentan una visión picaresca de la realidad y una actitud picaresca por parte del autor. El crítico señala que:

El autor picaresco, de todos los tiempos, es notoriamente intervencionista. Su método titiritero confirma una actitud ferozmente negativa ante la realidad; así, su narración suele ser una hipérbole de las peores tendencias sociales de su época. El se impone con su ideología, sus juicios y fobias morales, y su sistema estético (la caricatura, el juego malicioso de palabras, el diseño esperpéntico de los 
episodios, la visión antiheroica). Nos entrega un esquema de vida siempre contrario a lo que en cualquier sociedad se consideraría ideal; y no es casual que en varias épocas... hayan coincidido con el escepticismo antiheroico grandes sueños espirituales y utópicos. (987-988)

Afirma que el género está regido por tres constantes: circunstancialidad, desvalorización y revelación (989). De éstas, la circunstancialidad es el rasgo básico y la que da lugar a que se produzcan las otras dos. Por eso el pícaro es, como señala Peter Dunn, "a man of guises and disguises" (54).

Según Earle, las tres constantes antes señaladas siguen estando presentes en muchas obras de la literatura hispanoamericana contemporánea:

[. . .] las circunstancias condicionan, aunque no siempre determinen; se desvaloriza el status quo político, económico y cultural de las naciones americanas; la revelación no se manifiesta en forma de doctrina religiosa ni de sueño utópico, sino a través de una nueva sensibilidad que abarca el amor, la magia, lo cómico, y la violencia. (991)

Obras como Los de abajo de Mariano Azuela, Don Segundo Sombra de Ricardo Güiraldes, La increíble y triste historia de la cándida Eréndira y de su abuela desalmada de García Márquez, y Eva Luna de Isabel Allende, 
le sirven al crítico para ilustrar sus propuestas y demostrar que el germen de la picaresca tradicional, aunque metamorfoseado, puede rastrearse en nuestra literatura actual.

\section{Psicología del pícaro.}

Al redefinir y ampliar el alcance del género picaresco y proyectarlo más allá de sus orígenes en la España de los siglos XVI y XVII, podríamos hablar de una "psicología del pícaro" cuya influencia, como se ha demostrado anteriormente se ha hecho sentir hasta nuestros tiempos. El picarismo es más bien una forma de enfrentarse con la vida y está determinado por las condiciones sociales, políticas, económicas y culturales presentes en el mundo que rodea al personaje. Así, la psicología del pícaro está condicionada por el encuentro inicial con una sociedad cruel y hostil contra la que tiene que luchar, y por un ambiente y unas condiciones de vida que le producen un complejo de inferioridad. Su vida transcurre como un continuo enfrentamiento con las condiciones desfavorables que lo rodean, y como carece de valor, y el concepto del honor no tiene ningún significado para él, la trampa, la burla y el subterfugio son sus armas para defenderse.

El pícaro es internamente inestable, cambiante. No es capaz de seguir un curso de acción lógico y predeterminado, ni de mantener una posición estable fuera del mundo caótico que lo rodea. Debido a esa 
personalidad proteica, no hay un rol en la sociedad que el pícaro no sea capaz de asumir. El es el hombre que tiene que ser ante cada circunstancia y por tanto no es ningún hombre en particular. Es un ser acomodaticio que no quiere cambiar el orden social donde se desarrolla, lo que quiere es cambiar su posición dentro del mismo. Para lograr su objetivo, se vale de los mismos vicios que critica, y de los que se siente víctima.

Sostiene Maravall que todos los pícaros tienen "una doble pretensión: primero, la de ascender en la escala social; segundo, la de hacerlo fuera de los cauces establecidos. Y esto último es así porque el pícaro sabe que tales cauces nunca serán transitables para él [. . .]" ("La aspiración" 616), y afirma que "es propio de la vida del pícaro, [. . .] que esa ascensión se intente una y otra vez por la 'industria' del mismo individuo, quien usa de sus recursos en el juego, en su relación con la mujer, en su papel de servidor, hasta de creyente [. . .]" ("La aspiración" 608-609). De las ideas planteadas por Maravall, puede deducirse que el pícaro es un personaje que a pesar de su afán de medro, rehúsa incorporarse de forma legítima a su sociedad y rechaza el papel que le toca representar.

Tomando en cuenta todo lo antes expresado, se puede concluir que la psicología del pícaro es la que se manifiesta en la actitud de un personaje antihéroe que, tratando de sobrevivir en condiciones adversas 
dentro de su medio ambiente, y no siendo capaz de lograrlo por medios convencionales, recurre al engaño, la trampa y otros vicios para poder elevarse a una posición y a un status social que no le pertenecen. 
Capítulo Segundo. Sobre Cuba y los cubanos, 1902-1933.

José Antonio Portuondo afirma que en la literatura cubana, al igual que en la hispanoamericana, "el carácter dominante [. . .] es [. . .] la preocupación social, la actitud criticista que manifiestan las obras, su función instrumental en el proceso histórico de las naciones respectivas" (84). Basándonos en este postulado, nos parece de primordial importancia llevar a cabo un estudio de las condiciones existentes en el aspecto social, económico y cultural durante el período comprendido entre los años 1902 y 1933 para luego poder llegar a una mejor interpretación de la narrativa de la época.

El período que abarca de 1902 a 1933 fue una de las épocas de mayor importancia para Cuba. Históricamente, el año de 1902 marca uno de los más grandes acontecimientos, ya que después de haber sufrido siglos de coloniaje español, casi un siglo de luchas independentistas y tres años de intervención norteamericana, finalmente se instauraría la República. Por primera vez, los cubanos tienen la oportunidad y también la responsabilidad, de encauzar a Cuba como un país libre y soberano. Ese período, que se iniciara con gran júbilo por parte del pueblo cubano, terminaría en 1933, con el derrocamiento de la férrea dictadura de Gerardo Machado y con el comienzo de otra lucha revolucionaria por parte de las nuevas generaciones, esta vez para tratar de llevar al país por los caminos de la democracia. 
Con el surgimiento y desarrollo de la República, se producen una serie de cambios en algunos aspectos de la vida del país, mientras que en otros se sigue una trayectoria ya iniciada en la época colonial. Dentro del ámbito de la política se observa que algunos de los partidos que habían surgido durante el movimiento independentista desaparecieron, por no ser ya válidos sus objetivos; mientras tanto se formaron otros, de cara a las nuevas necesidades existentes en el país. Como se habrá de señalar más adelante, algunos de esos partidos carecían de una ideología sólida y de un programa de acción concreto. En cuanto a lo social, al instaurarse la República, según la opinión de algunos historiadores, la sociedad cubana está casi en estado embrionario. Diego Vicente Tejera afirma que "no puede verse en ella [.. .] sino un simple conjunto de elementos, no cristalizados todavía: elementos que no son contrarios, ni siquiera muy disímiles [. . .]" ("La sociedad cubana" 366). El historiador achaca la existencia de este fenómeno que él llama "vaguedad social" al origen totalmente plebeyo de la población cubana. Sería ya después, más avanzado el período, cuando veremos surgir diferentes clases sociales caracterizadas por rasgos muy distintivos. En el aspecto económico, la República trajo un cambio más bien aparente. Si durante la época colonial la economía cubana se desenvolvía solamente en función de los intereses de la Corona, a partir de 1898 y con la intervención militar de los Estados Unidos, la misma estaba regida por las conveniencias comerciales de este 
país. Fue ésta una de las situaciones que dio lugar a la inestabilidad económica, política y social que caracteriza a todo el período.

\section{El proceso histórico.}

\section{A) De la conquista y colonización.}

Como ya habíamos mencionado anteriormente, el período que nos ocupa es uno de los más importantes en la historia de Cuba. Sin embargo, es necesario retroceder un poco para comprender cómo y por qué se llega al momento que inicia esta primera etapa republicana, ya que las circunstancias que se dan en 1902 y hasta 1933 son, en muchos casos, el resultado directo de unas condiciones políticas y socioeconómicas previas. La conquista y colonización de Cuba por parte de los conquistadores españoles se inicia alrededor del año 1511. A partir de este momento, se comienzan a sentar las bases para un proceso de casi cuatrocientos años de dominación y vasallaje, de luchas y fracasos que, aparentemente, termina en 1902 con la instauración de la República. También durante estos años de presencia europea se inicia la germinación de lo que después sería la nacionalidad cubana.

Durante el resto del siglo XVI y casi hasta finales del XVII, la Isla sufrió el proceso de conquista característico de los tiempos. Se inició la fundación de poblaciones, sobre todo en áreas de fácil acceso marítimo, y pronto las constantes guerras en las que España estaba involucrada 
contra Francia, Holanda e Inglaterra junto, con otros factores políticos y económicos, dieron lugar a los ataques de corsarios y piratas que saqueaban las poblaciones costeras del Caribe. También la influencia del clero fue importante durante esta época. Como en el resto de los territorios descubiertos y conquistados por europeos, en Cuba se vio la explotación y el maltrato de los aborígenes, que pronto desaparecieron sin dejar casi influencia de su presencia en esa tierra. Casi desde los inicios de la conquista se estableció el sistema de encomiendas, mediante el cual se entregaba "a cada vecino un poblado indígena, cuyos habitantes serían puestos a trabajar, pagándoles un salario, y con la obligación de dejarlos volver a sus casas al terminar la labor" (Masó, Historia 33). Como los indígenas no estaban acostumbrados al trabajo a que se les sometía y algunos encomenderos no cuidaban de los mismos, el sistema fue en gran parte el causante de la extinción definitiva de los aborígenes. Fueron precisamente algunos clérigos quienes más lucharon por la aprobación de medidas protectoras a favor de los indígenas, especialmente el Padre Bartolomé de las Casas que habiendo sido al principio encomendero, renunció a su encomienda y dedicó su vida a defender los derechos de los indígenas ante los reyes españoles. Sin embargo, las gestiones de De las Casas y sus seguidores habría de traer otra consecuencia para el futuro pueblo cubano: la introducción de negros esclavos traídos desde Africa. 
A partir de fines del siglo XVII se observa un cambio en las condiciones existentes en los territorios conquistados. Las naciones europeas deciden retirar su apoyo al filibusterismo imperante en América en los siglos XVI y XVII. También la decadencia del poder naval y de la monarquía española contribuye a la modificación del sistema de flotas y al contrabando. Todos estos factores ayudan a "la transformación del territorio cubano en una colonia de plantación, por el desarrollo del comercio de exportación basado en el tabaco y el azúcar" (Masó, Historia 75). Estas nuevas condiciones económicas trajeron como consecuencia nuevos conflictos entre la naciente población criolla y los colonos españoles. La primera manifestación de rebeldía documentada por los historiadores, se conoce como la insurrección de los vegueros que ocurrió en 1717 y se debió a medidas dictadas por el rey de España para suprimir el libre comercio del tabaco en la Isla. Las rebeliones y manifestaciones de descontento continuaron hasta 1723, cuando los vegueros de zonas cercanas a la Habana arrasaron con las cosechas. Los causantes de esta última revuelta fueron hechos prisioneros, juzgados y ejecutados. Sus cuerpos fueron exhibidos en horcas cerca de la Habana para que sirvieran de escarmiento a futuros rebeldes.

Otro hecho de esta época que tuvo consecuencias significativas en el desarrollo posterior de la vida de la República, fue la toma de la Habana por los ingleses en el año 1762 y que se extendió hasta 
principios de 1763. La presencia inglesa en la Isla abrió el comercio libre con Inglaterra, y con este comercio entraron alrededor de diez mil africanos. Algunos historiadores son de la opinión que la mayor importancia de este episodio fue la experiencia que tuvo el pueblo cubano ante una política comercial diferente a la que estaba sometido por la Corona española, puesto que la misma les dio la oportunidad de expandir sus horizontes hacia otras realidades. Sin embargo, la presencia inglesa en La Habana también trajo otras consecuencias además de las de índole económica. Los ingleses, como señala el historiador cubano Herminio Portell Vilá, "introdujeron el protestantismo y la masonería" (1920) en Cuba. Andando el tiempo veremos que a diferencia de los demás países hispanoamericanos, la Iglesia tendría menor importancia y control en el desarrollo de la sociedad cubana republicana.'

Es importante destacar que fue en este período, y como afirma Calixto Masó, que:

La transformación de la Factoría en Colonia, junto con una serie de acontecimientos de carácter internacional en el campo de las ideas y de los hechos, facilitaron en Cuba y en el continente americano, la formación de la conciencia y del modo de ser de los países de nuestro continente, integrándose así en Cuba la personalidad colonial que es el antecedente de la nacionalidad. (Historia 97) 
No podemos olvidar que éstos fueron unos tiempos de gran evolución en el campo de las ideas. Los principios que regían a la humanidad sufrieron drásticos cambios a fines del siglo XVIII y principios del XIX y surgen así, en esta época, el liberalismo y las ideas democráticas. Las consecuencias de estas nuevas tendencias no se hicieron esperar y la humanidad vio resultados concretos en la Guerra de Independencia de los Estados Unidos, iniciada en 1775 y en la Revolución Francesa de 1789 , hechos que sirvieron de acicate al resto de las colonias oprimidas por una metrópoli.

En Cuba, el gobierno de Carlos III, respondiendo a la doctrina del Despotismo llustrado, alentó el espíritu de reforma tratando de mejorar la situación de la Colonia mediante su progreso material. También algunos historiadores consideran que en Cuba se intensifica el progreso con el trabajo esclavo "que a partir del siglo XVIII constituye el trasfondo de las ideas, la economía y la sociedad cubana" (Masó, Historia 98). Comienzan aquí también a perfilarse los diferentes elementos sociales que resultarán determinantes en el proceso histórico y revolucionario del siglo XIX, "constituyendo la esclavitud la explicación última de las actitudes políticas de los diversos grupos en que se dividía la sociedad" (Masó Historia 98).

Desde los últimos años del siglo XVIII, en la historia de Cuba empieza a perfilarse el proceso, por parte de los cubanos, de separación 
del territorio y la sociedad cubana de la española. En este período, los criollos y los peninsulares van separándose cada vez más, tanto por la cultura como por los intereses de cada grupo. Es en este momento, en opinión de Calixto Masó, en que "apuntan las principales tendencias políticas cubanas, el reformismo [. . .] y el separatismo" (Historia 107).

Culturalmente, la sociedad cubana fue inferior a la de otras colonias españolas en América hasta el siglo XVIII. Es a partir de este momento que empiezan a observarse en la Isla los primeros pasos hacia su evolución cultural, como lo ilustran la introducción de la imprenta en 1720, la fundación de la Universidad de la Habana en 1721 y la del Real Seminario de San Carlos y San Ambrosio en 1773. También datan de finales del siglo XVIII la aparición de La Sociedad Patriótica y la impresión del Papel Periódico.

\section{B) Las luchas por la independencia.}

A partir del año 1837 la historia de Cuba cambia. El proceso revolucionario llena la mayor parte del período que en este año se inicia y surgen una serie de conspiraciones y movimientos revolucionarios en todo el territorio cubano, en los que participan hombres de todos los grupos sociales y de ideas y tendencias diferentes, muchos de los cuales se convertirían más tarde en los dirigentes de la gesta independentista de 1868. También característico de este momento es el fraccionamiento de la sociedad cubana como consecuencia de las ideas y tendencias políticas 
y sociales. Algunas de estas tendencias fueron predominantes en ciertos momentos y perdieron su efectividad posteriormente.

Llegado el año 1868 se observa

el predominio de la tendencia separatista de carácter independentista [. . .] quedando relegado a un segundo plano lo económico, pues el cubano, [. . .] expresó su voluntad de ser libre e independiente, así como su voluntad, más que social humana, de la igualdad. (Masó, Historia 235) En la madrugada del 10 de octubre de 1868 se inició la guerra de los diez años. En 1878 , y cuando ya se hace imposible resistir, los cubanos firman con el gobierno español el Pacto del Zanjón que, entre otras concesiones, otorgaba amnistía a los libertadores dentro y fuera de Cuba y libertad a los esclavos africanos que pertenecieran al ejército libertador. El Pacto, aunque significara para algunos una claudicación de los libertadores ante el poder de España, fue un paso importante en cuanto a la situación de los cubanos con respecto a España. Afirma Octavio R. Costa que "los historiadores están de acuerdo en que por encima de las limitaciones del Pacto éste significó el reconocimiento de la existencia del pueblo de Cuba como una entidad distinta de España, separada de España y enfrentada a España" (1: 268).

Al terminar la Guerra de los Diez Años, la situación económica de la Isla es extremadamente difícil. Esto trajo también como consecuencia 
una alteración en el orden social. En esta época, el fraude y el contrabando, tan característicos del sistema colonial, se agudizan drásticamente, y el bandolerismo toma un auge como nunca antes se había visto en el país, debido a la gran inestabilidad de la vida social y la economía. Otro elemento que afectó la vida social en este momento es la abolición de la esclavitud, como consecuencia del Pacto del Zanjón, y la consiguiente incorporación de esta población a la naciente sociedad cubana.

Con el Pacto, la historia y la sociedad cubanas sufren una transformación. El mismo permitía a los cubanos formar partidos políticos y les concedía suficiente libertad para llevar a cabo sus actividades. Según afirma Calixto Masó, a partir de este momento "puede hablarse de vida política y de partidos en Cuba [. . .]" (Historia 295). Surgen en esta época dos partidos políticos: el autonomista y el separatista. Los mismos se diferenciaban más por su propaganda que por su programa. Fueron tiempos de lucha contra los gobernantes españoles de la Isla y entre los propios cubanos, para hacer prevalecer sus ideales con respecto al futuro de Cuba.

Transcurridos un poco más de quince años, se inician de nuevo las hostilidades contra España con el propósito de lograr la independencia. Tras numerosos enfrentamientos entre las figuras líderes, triunfa finalmente, el separatismo de carácter independentista y se decide un 
nuevo alzamiento. En febrero de 1895 se daría inicio a la Guerra de Independencia de Cuba. Cuando ya la guerra estaba por terminar, con victoria para el Ejército Libertador, se produjo un hecho que habría de marcar de forma definitiva el destino de la Isla. En febrero de 1898 explota en la bahía de la Habana el acorazado norteamericano Maine. El entonces presidente de Estados Unidos, William Mac Kinley, presionado por el pueblo y el Congreso norteamericanos, firma la Resolución Conjunta, en la que declara al pueblo de Cuba soberano e independiente. Pocos días después de firmado este documento Washington declaraba el estado de guerra contra España y las tropas norteamericanas entraban en territorio cubano. Esta breve contienda entre España y Estados Unidos en suelo cubano terminó con la firma del Tratado de París (octubre, 1898), mediante el cual los Estados Unidos adquirieron el derecho de ejercer funciones de gobierno en la Isla de Cuba mientras durara la ocupación militar. El pueblo cubano obtenía por fin su independencia, pero no como el resultado de una victoria en la guerra, sino como parte de las negociaciones entre España y los Estados Unidos. A partir de este momento, los destinos de la isla de Cuba estarían definitivamente ligados a los intereses de sus vecinos del norte.

C) Los primeros pasos hacia la república.

Al terminar la dominación española, la Isla se encontraba en una situación de atraso tanto en lo social como en lo económico, 
consecuencia de los cuatrocientos años de coloniaje y de los estragos sufridos por la guerra. La industria azucarera estaba destrozada, las condiciones sanitarias eran deplorables y la educación estaba en pésimas condiciones. El número de escuelas se había reducido drásticamente y existía un alto índice de analfabetismo. Fueron éstas las condiciones a que tuvieron que enfrentarse los gobernadores norteamericanos de Cuba durante la ocupación. Con la ayuda de un gabinete cubano y poniendo al frente de provincias y pueblos a destacados jefes del ejército libertador, se trataría de iniciar la recuperación económica y social de la Isla.

Durante la ocupación militar las ideas y tendencias políticas fueron tomando forma, pero una vez más imperó la desunión. En vez de presentar una unidad frente a la política de los Estados Unidos, lo que existía era una división del país y un fraccionamiento de los partidos en dos núcleos: los que defendían la independencia absoluta y los que, con una muy enraizada mentalidad colonial, aceptaban la soberanía limitada por la presencia extranjera.

Éstas eran las condiciones cuando en el año 1900 se comienzan a dar los primeros pasos hacia la instauración de la República en Cuba y se anuncia la celebración de elecciones para escoger a los miembros de la Asamblea Constituyente. Pronto se inicia la organización de nuevos partidos políticos, y pronto también comienzan los conflictos entre ellos. Octavio R. Costa comenta que "las discrepancias eran más personalistas 
que ideológicas" (1: 321), y en palabras de Calixto Masó "dichos partidos carecían de ideología, programa y cohesión [. . .]" (Historia 432).

Una vez celebradas las elecciones, los miembros de la Asamblea no sólo tenían la tarea de redactar la Constitución por la que habría de regirse el gobierno republicano, sino también tendrían que tomar la decisión sobre la inclusión en la misma de un apéndice conocido con el nombre de la Enmienda Platt. El mencionado documento daba carta blanca a Washington para intervenir en Cuba una vez celebradas las elecciones presidenciales y terminada la ocupación militar, siempre que la estabilidad de la República estuviera en peligro. En realidad la Asamblea no tenía ninguna opción, pues si no se aceptaba la Enmienda, la ocupación norteamericana continuaría en Cuba indefinidamente. El 12 de junio de 1901 se aprueba la inclusión de la Enmienda Platt como apéndice de la Constitución de la República de Cuba, prefiriéndose la independencia y la instauración de la República con soberanía limitada a una ocupación extranjera.

Después de aprobada la Constitución y la inclusión de la Enmienda Platt, todo estaba listo para iniciar el proceso de elegir al primer presidente de la República de Cuba. Seguían vigentes los partidos políticos que se habían formado con vista a las elecciones anteriores. Esta primera elección presidencial se vería caracterizada por el fraude y la manipulación presentes también en elecciones posteriores durante este 
período. Surge como posible candidato don Tomás Estrada Palma, que no está afiliado a ninguno de los partidos políticos, pero que "era visto con simpatía por Washington" (Costa 1: 323). Su contrincante, Bartolomé Masó, era partidario de la soberanía absoluta de la Isla, y por tanto no convenía a los intereses norteamericanos. Después de una crisis en el desenvolvimiento del proceso preelectoral, Masó decide retirar su candidatura. De esta manera, al no tener contrincante, fue proclamado primer presidente de la República de Cuba don Tomás Estrada Palma en las elecciones de 1901, y el 20 de mayo de 1902 se instauraría la República de Cuba, poniendo término a la Primera Intervención americana en Cuba.

No puede negarse que la Intervención americana trajo para Cuba consecuencias muy positivas. Al iniciarse el período republicano, la isla había dejado atrás la miseria y la ruina y había iniciado un proceso de desarrollo tanto en lo material como en lo social. Durante la ocupación norteamericana se aumentó considerablemente el número de escuelas y el presupuesto dedicado a la enseñanza, se inauguraron nuevas facultades en la Universidad y el índice de analfabetismo disminuyó notablemente. También se realizaron grandes mejoras en el campo de las obras públicas, la administración y la salubridad.

D) Los primeros treinta años de vida republicana.

Este primer período de Cuba republicana se caracterizó por el 
predominio de lo económico sobre lo político. Debemos destacar que en 1902 no existían en Cuba, o eran de menor importancia, muchos de los grandes problemas sociales y económicos que durante muchos años han estado presentes en otras naciones latinoamericanas, como son la fuerte presencia de una oligarquía que controle todos los canales políticos aun a expensas del progreso, las grandes diferencias entre las clases sociales y la religión. Sin embargo, esta misma situación hace de Cuba un territorio totalmente vulnerable a la invasión de capital extranjero. En 1903 se firma el Tratado de Reciprocidad entre Cuba y Estados Unidos. Este tratado trajo como consecuencia la casi total dependencia de Cuba del mercado americano y del precio del azúcar, situación ésta que fue eje de los conflictos que matizaron todo el período.

La primera etapa republicana que se inicia con la presidencia de Estrada Palma, continuará con esa tónica. Dentro de un ambiente personalista, donde predominaban los intereses individuales sobre los nacionales, y con un gobierno presidencialista que llevaba al presidente a una actuación similar a la de los capitanes generales españoles en la época colonial, comienzan a desarrollarse el caudillismo y el caciquismo.

Aunque el gobierno de Estrada Palma se caracterizó por su honradez, por aumentar de forma notable el tesoro nacional, por mejoras en la educación, la sanidad y las obras públicas, los errores políticos que plagaron la república trajeron como consecuencia las luchas civiles, que 
se intensificaron cuando el presidente decide aspirar a la reelección. Todo el poder del gobierno favorecía la candidatura del presidente en funciones, a la vez que controlaba el proceso electoral. Los fraudes y el acoso a los que disentían hicieron que los partidos opositores que se habían aliado se negaran a participar en las elecciones. Una vez más, sin tener un contrincante, Tomás Estrada Palma fue reelecto presidente. Pronto surge una insurrección que llega a convertirse en rebelión general. Sintiéndose incapacitado para controlar la situación y acogiéndose a lo estipulado por la Enmienda Platt, el presidente le pide al gobierno de los Estados Unidos que intervenga para pacificar la Isla, pero como Washington se niega decide renunciar y con él, el gabinete en pleno. Al no poderse poner de acuerdo el Congreso para elegir un nuevo presidente, se fuerza una segunda intervención norteamericana que duraría hasta 1908.

A diferencia de la primera, la segunda intervención norteamericana fue funesta para Cuba. Esta época se caracterizó por la corrupción administrativa y por la existencia de un fenómeno que habría de convertirse en un mal crónico de la república: la botella. La botella era un cargo innecesario dentro del gobierno. El titular de la botella cobraba un sueldo del gobierno sin trabajar. Al terminar la intervención norteamericana los fondos del tesoro público habían desaparecido y la República estaba totalmente endeudada. 
También psicológica y socialmente, este período fue desastroso para la joven República. A partir de 1909, los valores morales y políticos del cubano sufren una total degeneración. El pueblo adopta una actitud irreverente hacia todo lo que tenga que ver con los valores nacionales o espirituales. De esta manera, como una mezcla de desilusión y gracia, de amargura y de humor, surge el choteo criollo, característica que se convertiría en parte esencial de nuestra psicología nacional, como una vía de escape ante las adversidades de la realidad.

Durante esta época el gobierno republicano cubano se convierte en un instrumento político que servía para proteger los intereses económicos, tanto extranjeros como nacionales. Gobernar en Cuba era sinónimo de obedecer, puesto que todo respondía al interés socioeconómico de algunos grupos. Esto trajo como consecuencia la corrupción administrativa y una cierta tolerancia hacia la falta de honradez de los políticos, siempre que los mismos respetaran y apoyaran las demandas de los sectores económicamente más influyentes. Todo este período está caracterizado por una ausencia de visión nacional por parte de los gobernantes que con tal de beneficiar sus propios intereses, accedían a hacer ciertos negocios con el extranjero aunque éstos perjudicaran la economía nacional.

En cuanto al aspecto de la política, puede afirmarse que no existía prácticamente ninguna diferencia entre los partidos políticos. No había 
programa ni ideas sólidas en ninguno de ellos. En realidad, la lucha política era solamente el método que usaba cierto sector de la población para controlar el poder y así disfrutar las ventajas del mismo. Cada uno de los gobernantes otorgaba puestos a sus amigos y parientes; de esta manera ciertos sectores de la población se veían favorecidos según quienes estuvieran en el poder. En numerosas ocasiones hubo revueltas por parte del partido opositor que alegaba fraude electoral. En muchos casos la manera de resolver estos conflictos era conceder privilegios a algunos miembros de la oposición para hacerlos callar. Este tipo de juegos y manipulaciones políticas, así como la falta de honestidad por parte de los gobernantes, hizo que la República se llegara a caracterizar por

el descreimiento en sus hombres públicos, y [. . . por una repulsa popular a intervenir en la política, considerándola menester de una casta descastada: la de los políticos de oficio adueñados de todo el aparato electoral, [. . .] $\sin$ marcadas diferencias ideológicas entre sí [. . .] aspirando por todos los medios al poder, con el agravante de que una vez adueñados de él surgía el deseo de perpetuarse en el mando [. . .]. (Lizaso 107)

Como muy bien señala Harry Swan "involvement in government became a way-of-life for a generation of Cubans kept from the wealth of their 
country by political and economic circumstances. They were Lazarus sitting beside the table [. . .] picking up the falling crumbs" (277).

Económicamente, esta época fue dominada por dos importantes factores: la expansión del cultivo de la caña de azúcar y la cada vez más creciente penetración del capital norteamericano. Entre los años de 1903 a 1914 la producción y exportación de azúcar a los Estados Unidos aumentó considerablemente, crecimiento que se mantuvo hasta 1920 debido a las condiciones que trajo el estallido de la Primera Guerra Mundial. Esta tendencia de latifundio y monocultivo a favor de la industria azucarera fueron negativas para la economía de la Isla. Durante los años antes señalados el cultivo de otros productos como el café, frutos, etc., y la cría de ganado se vieron grandemente afectados. La expansión de los latifundios afectó a los agricultores que se dedicaban a otro tipo de cultivos y también a los colonos que viéndose imposibilitados de moler la caña que cultivaban, tenían que venderla a los grandes ingenios. Otro factor que afectó a la población cubana fue el hecho de que el gobierno, presionado por los dueños de ingenios, aprobara la importación de macheteros de Jamaica y Haití que trabajaban por menos salario que los cubanos. Durante este período miles de trabajadores de las más bajas clases sociales llegaron a Cuba, manteniendo los bajos salarios y obstaculizando el proceso de homogenización de la población cubana. El azúcar se convirtió en la 
mejor y más rápida vía de enriquecimiento, en momentos en que el ansia de hacer dinero dominaba a gran parte de la población. Este período conocido como "la danza de los millones", terminó catastróficamente con "el minué de la miseria" cuando a mediados de 1920, el precio del azúcar empezó a disminuir drásticamente. Ya para principios de 1921 la economía de la República estaba totalmente devastada.

Si para algo sirvió la crisis económica de 1921 fue para abrirles los ojos a diferentes sectores de la población cubana. A partir de este momento se observa el nacimiento de una cierta actitud de resentimiento hacia la penetración norteamericana y el surgimiento de un nacionalismo, que si bien era de raíz económica, tendría como resultado el inicio de un cambio de política en otros aspectos de la sociedad. Era necesario proteger los intereses nacionales y ejercer un control sobre la ilimitada influencia de los Estados Unidos, tanto en la economía como en la política del país.

Simultáneamente con este nacionalismo económico, otra corriente más radical comenzó a desarrollarse. Los estudiantes, intelectuales y grupos de variada configuración ideológica empezaron a manifestar un comportamiento afín al sentimiento que empezaba a sentirse en toda América Latina. No cabe duda que esta nueva actitud también fue el resultado de otros hechos internacionales, como fueron la Revolución Mexicana de 1910, la Revolución Rusa de 1917 y las reformas 
universitarias de Córdoba, Argentina alrededor de 1918. La generación de los años veinte se rebeló contra el ambiente de corrupción y decadencia que imperaba en el país, haciendo resurgir el nacionalismo y las ansias de soberanía e independencia.

Uno de los primeros en tomar la iniciativa de cambio fue el presidente Alfredo Zayas. Su actitud ante la política de penetración e intromisión del gobierno de los Estados Unidos fue ejemplar, al desafiar la imposición, por parte del General Crowder, de un "gabinete de honradez" para que controlara la administración de Zayas. Sin embargo, su gobierno se caracterizó por la corrupción administrativa. "During this period, the politician became a type: he was a ventajista, a trepador, an individual without moral scruple who threw himself into the political arena with an exclusively mercenary purpose" (Swan 280).

Este primer período republicano llega a su culminación con la elección en 1924 de Gerardo Machado como presidente. Machado se había presentado ante el electorado, ansioso de soberanía y honestidad en el gobierno, con una aureola de falso nacionalismo y las promesas de tener un gobierno honrado. Aunque su gobierno tuvo en los primeros años "una tónica de regeneración cívica y de fecunda actividad constructiva" (Márquez Sterling, Historia de la Isla 183), había en él ciertas inclinaciones autoritarias, y pronto aparecerían los primeros síntomas de la dictadura: utilización de militares para desempeñar tareas 
de supervisión de los servicios públicos, intervención del Presidente en fallos judiciales, asesinatos de periodistas que criticaron al gobierno o a la familia del presidente, y un gran afán de preservar a toda costa el orden en la Isla.

No cabe duda de que, desde los inicios, existían en Gerardo Machado las intenciones de perpetuarse en el poder. A este propósito se inventó una fórmula denominada el cooperativismo mediante la cual se deshacía de toda oposición política. Después que su mandato fue extendido por dos años por el Congreso, la Asamblea Constituyente incumplió la ley constitucional de no-reelección y Machado se convirtió en el candidato único que representaba a los tres partidos existentes en la época. En las elecciones de 1929 fue reelecto para un nuevo término de seis años.

Las manipulaciones por parte del Congreso y la reelección de Machado, junto con la situación de miseria económica y desesperación en la que se encontraba el país, dieron lugar a abundantes protestas de los más variados sectores de la población: estudiantes, intelectuales, trabajadores. A partir de este momento empieza a manifestarse abiertamente la necesidad de un cambio radical en Cuba, iniciándose así la crisis del machadato. Tanto las manifestaciones callejeras como los actos de terrorismo no se hicieron esperar. Como respuesta, y en su afán de mantenerse en el poder, Machado toma medidas enérgicas: cierre de 
todas las instituciones educacionales, censura de la prensa y creación de un grupo denominado La Porra que se encargaba de liquidar a los enemigos del dictador y reprimir todo acto de rebeldía.

Después de cuatro años de asesinatos, miseria, terrorismo y falta de garantías constitucionales, Gerardo Machado, forzado por varios pronunciamientos militares y por el gobierno de Estados Unidos que estaba dispuesto a intervenir si no se producía su renuncia, decide abandonar la presidencia el 12 de agosto de 1933. "Así quedó el país [. . .] bajo el signo de una profunda revolución que tendría largas repercusiones" (Márquez Sterling, Historia de Ia Isla 193) en el período que a partir de aquí se inicia.

\section{Hacia la formación de la identidad nacional.}

Aunque ya desde los tiempos coloniales empieza a observarse en la población criolla de la Isla una identidad nacional que va surgiendo a partir de los diferentes grupos étnicos que la conforman, es en realidad, con los comienzos de la República que se observa una demarcación de los rasgos distintivos de la nacionalidad cubana. Las nuevas condiciones políticas y económicas tienen gran influencia en el origen y la reafirmación de algunas de nuestras características más sobresalientes. Se puede afirmar, sin lugar a dudas que 
la nación cubana, [. . .] es el producto del dramático laboreo de siglos, con la incorporación fecunda de grupos étnicos y nacionalidad diversas. Asentado en un suelo fértil, en un espacio geográfico que le imprime su sello característico, el pueblo cubano es el resultado de numerosos acontecimientos que van encadenándose desde el instante mismo del descubrimiento. (Chain 97)

\section{A) Herencia étnica del pueblo cubano.}

El conocimiento de la historia de la isla de Cuba nos lleva a deducir que en la raíz de la nacionalidad cubana confluyen varias razas que aportaron sus rasgos característicos y dejaron su huella en nuestra identidad nacional. El pueblo cubano se fue formando, como bien afirma Juan Bosch, "sobre un fondo escaso de indígenas, con el aluvión de los conquistadores hispanos y los negros esclavos" (88). Al principio, fueron estas tres razas las que se mezclaron en el crisol de la Isla, más tarde se añadiría el elemento oriental. A través del devenir histórico, estas razas sufrirían también la influencia del medio ambiente e irían evolucionando de acuerdo con las condiciones políticas y sociales, dando lugar a una psicología nacional cubana. Es por eso que "en Cuba [. . . ] no existe la homogeneidad en la población. Factores diversos, elementos disímiles y razas de opuestos caracteres psicológicos, han contribuido a formar nuestros tipos étnicos [ . . ]" (Masó, El carácter 35). 
El indio, como raza pura, no tardó en desaparecer y por eso, el sustrato indígena, presente en el momento del descubrimiento y en los inicios de la conquista, no influyó de modo directo en la formación del carácter nacional, aunque "desde el punto de vista psicológico una concordancia afectiva nos liga con los sentimientos de esta raza" (Masó, El carácter 66).

Desde el momento en que se inicia la conquista de la Isla, la raza blanca se convirtió en el núcleo principal de la población. Los primeros conquistadores que llegaron a tierras cubanas eran en su mayoría andaluces y castellanos. Más tarde, según fue avanzando el proceso, se incorporaron otros elementos como canarios, gallegos y otros pueblos del norte de España. En un momento posterior, a raíz de los incidentes ocurridos en Haití, la presencia francesa también se hizo sentir en Cuba. En el siglo XIX hay un aumento en la emigración española, esta nueva presencia peninsular da lugar a que se inicie la diferenciación de los blancos en Cuba: los criollos (blancos nacidos en la Isla) y los peninsulares.

Como ya se ha mencionado, la raza blanca, representada en los comienzos por el conquistador español, ha sido siempre el núcleo principal de la población cubana. Sin embargo, es importante recordar que el español es también un producto de la mezcla de muchas etnias que confluyeron en la Península Ibérica a través de su historia, y muchos 
de nuestros rasgos son de origen mediterráneo. La etnia española es resultado de la combinación de los rasgos presentes en la psicología de sus numerosos pobladores:

Los árabes le dieron su indolencia y su fanatismo. Los godos, su altivez y su valor. Los iberos, su tenacidad. Los celtas, su carácter belicoso. Los euroafricanos, su indisciplina originaria. Y los latinos, su genio emigrante y colonizador, y su disposición extraordinaria [ . . .] para la producción literaria. (Masó, El carácter 54)

Otro de los elementos de capital importancia en la formación de nuestro carácter nacional es el negro. La situación de esta raza no es la misma que la de los indígenas. Mientras que estos últimos permanecieron en contacto con su paisaje, sus costumbres y sus dioses, a pesar de la presencia de los conquistadores, el negro fue substraído de su ambiente; se le arrebató, de golpe, al meterlo en las sentinas de los barcos que lo trajeron a América, el paisaje africano [. . .] la fauna y la flora... A menudo en la dotación de esclavos en la que caía, ni siquiera había quien hablara su lengua nativa [. . .]. (Bosch 89)

De esta manera al negro se le hacía casi imposible conservar su religión o su idioma, sin embargo "un mecanismo de defensa psicológica lo llevó 
a adaptarse con gran rapidez al nuevo ambiente" (Bosch 89). Es por eso que en este proceso de mezcla de razas, se dice que el indígena es un elemento estático, mientras que el negro es un elemento dinámico. Este último, durante el proceso de adaptación, también afecta a los otros grupos étnicos con los que entra en contacto.

Durante el período de la colonia de plantaciones, el fenómeno de la esclavitud "provoca la inserción de nuevas nacionalidades en una proporción cuantitativamente muy considerable. Se trata de las nacionalidades africanas: congos, carabalí, lucumí y otras muchas" (Chain 105). A partir de este momento, y hasta ya bastante entrado el siglo $X I X$, llegaron a Cuba miles de negros africanos que mediante un proceso de transculturación, aportaron elementos de su etnia a la naciente nacionalidad cubana.

Hay que señalar que dada la diversidad de grupos de la raza negra que llegaron a Cuba, se hace difícil determinar con exactitud los rasgos psíquicos definitorios de cada uno. En la siguiente cita, Calixto Masó resume el juicio de Fernando Ortiz sobre esta situación:

En nuestra Isla están representados todos los tipos negros que pueblan el extremo Occidental de Africa y hasta muchos de las regiones Central y Oriental, aunque los que más han influído en nuestras condiciones psicológicas [. . . ] son los yolofes, senegales aguerridos, belicosos y difíciles de 
gobernar, aunque excelentes cuando no eran indisciplinados; los mandingas, de color moreno claro, mansos, de carácter fácilmente moldeable, francos hospitalarios y apreciados como los más aptos para el trabajo embrutecedor de los ingenios; los bambaras, muy robustos, pero en extremo fatalistas y torpes, de condición voluble, muy perezosos e inclinados al robo; los lucumis inteligentes y civilizados, pero altivos, arrogantes y muy difícil de sujetar a la esclavitud; los ararás, dóciles y muy poco sensibles a los horrores de la Trata; los dajomés, muy malos esclavos, porque añorando siempre sus recuerdos del Africa terminaban comúnmente en el suicidio; los minas, delicados, femeniles, impresionables y en extremo cobardes en las enfermedades; los carabalis, generalmente buenos, amantes del trabajo y cumplidores de sus obligaciones, y aunque en su tierra tenían fama de antropófagos, [. . .] en Cuba eran los negros que más comúnmente con su peculio se proporcionaban no sólo la libertad sino también cierta independencia económica; y los bisayos, soberbios e indomables [. . .]. (El carácter 68-69) Aunque existió la amalgama de los grupos antes mencionados, "la psicología del negro en general es tan primitiva, sobre todo en los pueblos que surtieron el mercado negrero, es relativamente tan poco 
compleja, que las diferencias de uno a otro no pueden ser de gran cuantía" (Ortiz, Los negros esclavos 69), con el diario convivir y debido al proceso de adaptación en un medio ambiente ajeno, los negros en Cuba fueron "apropiándose recíprocamente los caracteres psíquicos de los que, aunque en su propia raza, eran más civilizados [. . .]" (Ortiz, Los negros esclavos 69).

En un intento por describir los rasgos psicológicos más sobresalientes de los negros esclavos en general, Fernando Ortiz dice que:

el negro africano fue traído a Cuba en la más completa desnudez física y psicológica. El negro en este estado, era como decía Girard de Rialle 'un niño grande, entregado a la impresión del momento y absolutamente esclavo de sus pasiones. Así, se manifiestan en él las contradicciones más sorprendentes en su conducta. Es ligero, inconsistente, alegre, reidor, amante del placer con frenesí, loco por el baile, el ruido y los vestidos chillones y llamativos.' Los etnólogos completan estos trazos pintándonos los pueblos africanos que dieron su carne a la trata abominable, como naturalmente indolentes, de sensualidad desbordante, faltos de previsión, supersticiosos sin límites, de inteligencia poco despierta y enemigos de las ideas abstractas, tímidos de 
espíritu ante lo desconocido, aunque valerosos ante el peligro real, caritativos, amantes de su terruño y presa de añoranzas en tierras extrañas por el recuerdo del país nativo, llenos de devoción a los hijos y dados a la buena amistad [. . .]. (Los negros esclavos 70)

Otros rasgos que se le señalan a la raza negra son la frivolidad y la vanidad; la tendencia a la risa, la mentira, la broma y la tacañería; se advierte también en esta raza una gran curiosidad y un espíritu de imitación. Florinda Alzaga, por su parte, le atribuye a esta etnia las siguientes características: sincretismo religioso, sentido de la jerarquía, sentido de conformidad y de aceptación pasiva que lo lleva a la inacción, sentido de autoafirmación e inconsciencia económica. También comenta que es característica del negro ese encontrar la esperanza en el dolor y el humorismo, antecedente del choteo que tanto caracteriza al pueblo cubano (21-26).

Por otra parte, no puede dejar de mencionarse el hecho de que el negro llega a Cuba en condiciones de esclavo y, por lo tanto, muchos de sus rasgos esenciales se verían alterados por las prácticas de la esclavitud y la inmoralidad existente en la colonia, fomentando instintos antisociales de licencia y libertinaje. Plantea Masó que los esclavos solamente adquirían de sus amos vicios y que muchos de ellos 
terminaban convertidos en criminales y bandoleros a instancias de sus propios amos (El carácter 78).

El último elemento que tiene cierta relevancia en el desarrollo de la nacionalidad cubana, es el asiático. La llegada de los chinos a Cuba se inicia a mediados del siglo XIX, cuando los esclavistas, atemorizados por los sucesos acaecidos en Haití, no se atreven a aumentar la población africana a pesar de que necesitan la mano de obra. Más tarde, con la supresión definitiva de la trata de esclavos, se busca la manera de traer colonos chinos para que realicen el trabajo agrícola. Este elemento étnico influyó muy poco en la formación del carácter cubano.

B) Origen y formación de la nacionalidad cubana.

Es acertada la afirmación de Juan Bosch de que "la sola convivencia o la mezcolanza racial no forman un pueblo" (90), ya que, según la opinión de numerosos sociólogos, existe nacionalidad donde hay hombres unidos por simpatías comunes y donde se halla presente un espíritu público común. Sin embargo, los pobladores de Cuba en muchas ocasiones tuvieron que enfrentar situaciones que los unirían sentimentalmente. Baste como ejemplo la defensa de las poblaciones costeras contra los ataques de los corsarios y piratas. La formación de la nacionalidad cubana es un proceso paralelo a su acontecer histórico. La historia de Cuba ha sido dividida en diferentes períodos, caracterizados cada uno de ellos por determinadas circunstancias económicas, políticas 
y sociales, y en cada uno de estos períodos se puede observar el proceso evolutivo de la identidad nacional cubana al que fueron contribuyendo, como ya mencionamos anteriormente, una serie de grupos étnicos y de elementos políticos y socio-económicos.

Puede decirse que el primer paso en la formación de la nacionalidad cubana se observa a partir de la segunda mitad del siglo XVI en que va surgiendo lo que se conoce como "lo criollo". Como afirma Calixto Masó, "no puede aún denominarse nacional, pero [. . .] ya se diferencia de lo español, de lo indígena y de lo africano" (Historia 69). El historiador atribuye este fenómeno al hecho de que circunstancias de índole económica, como el contrabando y la piratería, contribuyeron a desarrollar cierta autonomía en la vida de las poblaciones. También en esta época, el elemento negro le empieza a dar un matiz diferente a la vida y a las costumbres de los pobladores de la Isla. Se forma, de esta manera, lo que Masó llama "una personalidad de carácter factorial que es el antecedente de la colonial y de la nacionalidad" (Historia 70). Durante este período, "el hecho cubano fue diferenciándose del hecho español, demandando un tratamiento para sí, distinguiéndose en el mapa del vasto imperio americano. Al terminar el siglo XVII Cuba era ya Cuba, aunque ella misma lo ignorase" (Bosch 91).

Con el comienzo del siglo XVIII se acentúan en Cuba las influencias inglesas y francesas, y la centralización borbónica contribuye a aumentar 
la separación entre criollos y peninsulares. Por otra parte, económicamente se diferencian dos tipos de vida: la factorial y la rural. Los peninsulares, más dependientes del sistema de flotas se asentaban en La Habana; la vida rural, debido al aislamiento de las poblaciones, permitía más independencia a sus pobladores--los criollos-- que "sin dejar de ser españoles son el antecedente de lo cubano" (Masó, Historia 96). Uno de los hechos históricos de la época que dan testimonio de esa diferenciación de carácter, a la vez económico, político y social, es la rebelión de los vegueros, ocurrida en 1717 .

"Cuba se asomó al siglo XIX con una personalidad nacional ya vigorosamente definida en lo económico y en lo humano, con centros de población llenos de actividad, con cultura seria, aunque no ampliamente difundida, con problemas propios; más cerca de América que de España [. . .]" (Bosch 104). Con el inicio del proceso revolucionario alrededor de 1808 se hace aún más notable la diferenciación entre criollos y peninsulares. Los primeros, además de sentirse diferentes a los españoles, "tenían el orgullo de ser cubanos, se ocupaban del progreso de su país (y) de su cultura" (Masó, Historia 122). Había en los criollos una conciencia diferente que afectaba todos los aspectos de la vida, no solamente el social. Ya existe en ellos el concepto de patria y comienzan a aparecer los sentimientos independentistas. Calixto Masó opina que "el modo de ser del cubano ya estaba formado a principios del siglo XIX 
[. . .]" (179); sin embargo, algunas de nuestras características

psicológicas fueron apareciendo más tarde como consecuencia de las condiciones políticas, económicas y sociales que se dieron en la Isla aún después de instaurada la República.

C) Rasgos fundamentales de la psicología nacional.

El carácter nacional de cada pueblo está determinado por "causas físicas, antropológicas, psicológicas y sociales [. . . ] conjuntamente con la Historia [. . .]" (Masó, El carácter 19). Además es importante tomar en consideración el hecho de que no es

el carácter de un pueblo cosa fija e inmutable al través de todas las épocas de su historia, sino, por el contrario, algo que se modifica y transforma bajo la triple influencia de la educación [. . .]; del contacto con otras civilizaciones, [. . .] y [. . .] de las tendencias predominantes en las distintas épocas de su evolución. (Guiral 121-122)

En el caso del cubano, puede observarse que la influencia del medio ambiente ha sido un factor importante en la modificación de algunos aspectos del carácter nacional, puesto que, como afirma Carlos Chain, "la isla, carente de fronteras y colonizada por una sola potencia, ofrece el escenario geográfico necesario para el desarrollo de una nacionalidad diferenciada de la progenie española o africana" (99). Cuba sería el crisol donde se fundirían los diferentes componentes de las etnias, psicologías 
y culturas presentes desde los inicios de la colonización para dar lugar a la nacionalidad cubana. Por otra parte, veremos que algunas de nuestras características más distintivas surgen en los momentos en que ya Cuba era una República independiente.

Étnicamente, nuestro pueblo es el resultado del cruce de dos razas: la blanca y la negra; es por tanto un pueblo mestizo. El mestizo es un tipo nuevo, y numerosos sociólogos se han dedicado a su estudio y han señalado una serie de características esenciales. Calixto Masó plantea que "mezclar dos pueblos, es transformar su constitución física y mental y como es lógico que suceda, los caracteres así elaborados permanecen en su inicio flotantes y débiles, y sólo mediante largas acumulaciones hereditarias, se solidifican y hacen duraderos" (El carácter 83 ). Si tomamos como base la afirmación anterior, podemos deducir, que el carácter del cubano, en el momento de las luchas independentistas y los primeros tiempos de la República se halla en un estado de desarrollo, lleno de luchas interiores, puesto que aún no están fijados los nuevos rasgos psicológicos.

Los historiadores que han dedicado parte de su obra a analizar los rasgos caracterizadores de la psicología cubana en las primeras décadas del siglo XX, han observado que muchas de nuestras características son comunes a la de muchos pueblos latinoamericanos. En su estudio $E I$ carácter cubano, Calixto Masó comenta sobre algunas de las ideas que 
tenía Sarmiento sobre la conquista de América, y señala dos defectos presentes en la psicología del criollo: "el coraje indisciplinado y antisocial, y la pereza inerte y majestuosa" (88), que provienen del carácter español, y afirma

la pereza criolla [. . .] consiste en una absoluta falta de actividad material y espiritual, (y se) [. . . ] encuentra en la juventud exenta de ideales, en la política caracterizada por el caciquismo, en la administración judicial, voluble y sin conciencia [. . .], y en la poca dedicación a los trabajos comerciales, abandonados generalmente a los extranjeros.

También se les atribuye a los criollos de toda América Latina, como características fundamentales de su psiquis, la tristeza y la arrogancia.

Es opinión generalizada que Cuba es la más española y, por ende, la más euroafricana de todos los países latinoamericanos, de ahí que en el carácter del cubano se observen de forma más acentuada que en el de otros pueblos latinoamericanos, rasgos de la raza conquistadora.

Manuel Márquez Sterling ha expresado su juicio sobre algunos de los rasgos fundamentales de nuestra psicología nacional. Para este historiador, el criollo es más arrogante que perezoso; nuestra tristeza tiene más del cante andaluz, que del fatalismo del gaucho. También señala: 
la parte que tenemos de españoles, se nos conoce [. . .] en nuestros defectos [... . Somos exclusivistas, violentos, imprevisores y egoístas. Creemos ser todo aquello que no somos; queremos resolver todas las cuestiones que corresponden al pensamiento por medio del valor personal y la coacción; jamás miramos hacia el porvenir, preocupados siempre del problema diario [. . .]. (Alrededor de Nuestra Psicología 197-198)

Asímismo, muchos de nuestros sociólogos e historiadores han señalado entre los rasgos más destacados de nuestro carácter nacional, el desinterés, la llaneza y la hospitalidad. Del español, heredamos muchos de sus rasgos psicológicos, solamente que suavizados por la influencia del medio ambiente. Españoles son nuestra acendrada pasión y emotividad, nuestro estoicismo y también nuestro epicureismo. Una manifestación de lo español en nuestro carácter, y consecuencia de ese epicureismo, es el sentido del tiempo. "El tiempo [. . .] no tiene para nosotros un sentido primario astronómico medido en meridianos. Vivimos en un tiempo vital [. . .]. Por eso llegar tarde es algo secundario, y se concede, hispanamente, poca importancia a la puntualidad" (Alzaga 18). También del español nos viene nuestro sentido del honor, ligado estrechamente al concepto de la madre y de la familia. La familia hispana es grande y unida y en ella la madre tiene un papel principal. Relacionada 
con la familia y como extensión de la misma, está la amistad. El cubano es amistoso por naturaleza, y siente una necesidad innata de compartir y de conversar. Otro rasgo de lo español, y una de nuestras características más destacadas es el exagerado individualismo. "Nunca seremos manada; el yo reafirma constantemente su esencia [. . .]" (Alzaga 18). Esta característica, positiva si se sabe mantener el equilibrio; si se desmesura, puede llevarnos a una falta de unidad colectiva y al divisionismo, que se ha observado en muchos de los momentos más importantes de la historia de Cuba. También producto del individualismo son el caudillismo y la dictadura, fenómenos característicos de nuestra historia. Por último, también español es, quizás, el más complejo de todos nuestros rasgos: la extraña paradoja que entrelaza realismo e idealismo. Somos los cubanos Quijotes y Sanchos a la vez, y nuestro quijotismo nos lleva a ser imaginativos y valientes.

Masó afirma que "la base de la población española es de origen africano" (El carácter 49). De esta afirmación puede deducirse, que muchos de nuestros rasgos psicológicos tienen su origen en la cultura de los pueblos euroafricanos. Uno de ellos es la arrogancia, "esa altivez independiente hasta la anarquía [. . .]" (Masó El carácter 57), que es causa de nuestra falta de solidaridad y de nuestro exagerado culto al valor personal. Otra, es la tendencia a la hipérbole que no admite términos medios. Masó plantea que son estas características del español 
las que han dado lugar a "la truhanería inmortalizada en las novelas picarescas y su degeneración en la Edad Moderna, el tipo del matón tan magistralmente descrito por Cervantes, la fanfarronería, la verbosidad, la maledicencia [. . .]" (El carácter 64).

Por último, el historiador cubano afirma que

la indisciplina eurafricana es la característica fundamental del criollo cubano; y siempre, el predominio del individuo sobre la sociedad ha sido el fenómeno típico de nuestra evolución histórica [. . .] Nuestra sociedad es eurafricana en sus impulsos principales, y necesita [. . .] la dirección de una fuerte y poderosa voluntad individual [. . .] La indisciplina es la causa [. . .] de la arrogancia y el exceso de patriotismo español, que tanto se notan en nuestra psicología social. Nuestro carácter independiente y voluble es también una degeneración de esa exaltación individualista; y el culto exagerado al valor personal, el instinto de lucha, el deseo inmoderado de tener siempre razón y de endiosar nuestra personalidad intelectual, nuestra honradez y moralidad, las pasiones impulsivas y momentáneas que ciegan nuestra inteligencia y agotan nuestra voluntad, el excepticismo y la suficiencia estúpida [. . . ], la anarquía de todas las esferas de nuestra vida política, social y administrativa [. . . ] no son [. . . ] 
sino aspectos de ese individualismo eurafricano [. . . La imprevisión y la impaciencia, la oposición sistemática al gobierno [. . . ] son consecuencias directas de nuestra indisciplina originaria [. . .]. (El carácter 100-106)

También Mario Guiral Moreno, en su artículo "Aspectos censurables del carácter del cubano", hace referencia a la indisciplina cubana y lo califica como "el defecto capital de nuestro pueblo" (123).

A pesar de la tremenda influencia española que se observa en nuestra psiquis, es necesario señalar que el negro contribuyó a modificar nuestras características fundamentales de origen blanco. Según Calixto Masó,

al negro deben atribuirse, la excesiva vanidad del criollo, y su extrema susceptibilidad, que exacerbada por la arrogancia y la altivez hispana, le convierten en un pavo-real agresivo. La novelería, que le hace admirar y aceptar como niño-grande, todo lo que no conoce. La superstición y el temor pueril, ante el peligro desconocido. La extraordinaria facilidad para la música, y el sensualismo con un poco de brutal y un mucho de delicado [. . .]. (El carácter 107)

Algunas de estas características, como el sensualismo y la novelería, que en opinión de Masó, nos vienen de la influencia negra, son señaladas por Guiral como defectos de nuestro carácter. 
Entre otros aspectos censurables de nuestro carácter que destaca Guiral se encuentran el choteo, la informalidad, el pesimismo y lo que él denomina el carnerismo. El choteo, como ya hemos mencionado anteriormente, quizás tenga su antecedente en el humorismo de la raza negra; sin embargo, es un rasgo que se hace más sobresaliente a partir de la época republicana, y luego se convierte en una de nuestras características más salientes y generalizada. Según Guiral, "es Cuba el clásico país del choteo" (125). Jorge Mañach, por su parte, en su estudio titulado "Indagación del choteo", plantea que: "el choteo [. . .] consiste en 'no tomar nada en serio' [. . .] El choteo consiste en 'tirarlo todo a relajo'” (57). Hasta cierto punto, puede deducirse que el choteo está intimamente ligado a la indisciplina. Esta falta de respeto crónica se origina en el individualismo y la ausencia de sentido de la autoridad. Chotear "las cosas serias no será [. . .], más que desconocer [. . .] el elemento de autoridad que hay o pueda haber en ellas: crear en torno suyo un ambiente de libertinaje" (Mañach 58-59).

El choteo ha traído como consecuencia otra de nuestras características más distintivas: la informalidad. Como bien comenta Mario Guiral, "esta propensión a chotearse de todo, ha relajado los vínculos de respeto mutuo entre los ciudadanos y borrado las líneas de separación que en todos los países existen entre las distintas jerarquías sociales" (125). También consecuencia de este choteo son el desinterés y la 
despreocupación que el cubano demuestra hacia los más graves y difíciles problemas, así como la apatía y la indolencia que señala Diego Vicente Tejera, y el relajado sentido de la puntualidad.

Al hablar del pesimismo cubano, Mario Guiral comenta acertadamente que en muy pocos cubanos hay una visión optimista y una actitud esperanzada hacia el futuro. En la mayoría de los cubanos existe una propensión innata "a lamentarse, a quejarse, a renegar siempre de lo que ocurre, considerando como males irremediables y desgracias horribles las naturales contrariedades y los inevitables sinsabores que en todas partes se sufren [. . .]" (Guiral 128).

Por último, debemos comentar sobre el aspecto del carnerismo, o sea, "tener tan sufrida condición como el carnero, manso y dócil mamífero" (Guiral 130). El carnerismo lo atribuye Guiral a la falta de civismo que caracteriza al cubano. Íntimamente ligado a él está el individualismo exacerbado, que hace que el cubano no sea capaz de protestar de forma colectiva y masiva contra quienes violan sus derechos o los maltratan. "El pueblo cubano [. . . ] sólo se atreve a formular en voz baja su protesta [. . .] (pero) [. . .] pronto se resigna y acaba por acatar, sometiéndose, lo que nunca debió consentir" (Guiral 130). Esta condición da lugar a que se sometan al poder omnímodo de un caudillo o un dictador, realidad trágica de la historia de Cuba. 


\section{D) Tipología de la sociedad cubana.}

Nos parece acertado después de realizar el estudio de los rasgos fundamentales de la psicología nacional cubana, llevar a cabo un rastreo de los tipos que han surgido en nuestra sociedad como resultado de las más variadas combinaciones de esos rasgos. A mediados del siglo XIX, y cuando estaban en boga los aires costumbristas, aparece en Cuba un volumen titulado Los cubanos pintados por símismos, que contiene treinta y ocho artículos de costumbres donde se trata de "delinear el perfil físico y moral de los hombres y mujeres que habitaban la isla de Cuba [. . .] ( y de dar) un esbozo de muchos rasgos esenciales que constituyen la fisonomía del cubano" (Los cubanos ix). ${ }^{3}$ Debemos aclarar que según las normas del costumbrismo, "los tipos muestran el carácter o los rasgos personales de un individuo que representa a una colectividad" (Los cubanos xiii), y aunque este volumen es de publicación bastante anterior a la época en que se desarrolla la narrativa que nos ocupa, algunos de los tipos que se presentan en él están presentes en la sociedad cubana en las primeras décadas republicanas.

Como habíamos mencionado anteriormente, Los cubanos pintados por sí mismos ofrece el perfil moral de treinta y ocho tipos cubanos, tanto masculinos como femeninos, tanto urbanos como rurales. Como muy acertadamente comenta Reinaldo Sánchez, 
aunque estos tipos no son un producto esencialmente cubano, ya que tienen su contrapartida en tipos existentes en la sociedad española, sí podemos decir que ahora aparecen observados en relación con el medio social diferente que los ha ido modificando. Lo importante aquí consiste en el hecho de que esa tipología es el producto de realidades vividas que se traducen en un protagonista típico dentro de una situación característica, y no son meras representaciones de situaciones artificiales, creadas ex profeso. (760)

De entre los tipos incluidos en la mencionada obra, hemos seleccionado, a manera de ejemplo, algunos que presentan, a nuestro juicio, rasgos que los relacionan psicológicamente al pícaro, como veremos a continuación.

El primero de estos tipos es el mataperros. El autor de este artículo presenta a este tipo como un niño entre los ocho y los dieciséis años, edad en la que muchos de los personajes picarescos inician sus andanzas. Este tipo, "víctima infeliz del abandono de la infancia" (Los cubanos 317 ), se caracteriza por no haber tenido ningún tipo de instrucción escolar, pues tiene antipatía a las escuelas y es enemigo de todo lo que pueda restringir sus movimientos. De él dice el autor que: "La calle es su elemento favorito: es infractor de cuantas órdenes emanan del gobierno. [. . . ] Siempre anda sucio y mal vestido. [. . . ] Sabe evadirse 
muy bien de sus persecuciones, y si le oyen un momento, se disculpa á las mil maravillas y queda por inocente [. . .]" (Los cubanos 315$).{ }^{4}$ Otra característica que acerca al mataperros al pícaro es su vida en comunidad o partidas. ${ }^{5}$ Este personaje parece tener un olfato especial que lo hace "adivinar" cuándo y dónde hay un acto donde pueda realizar sus fechorías, tales como bailecitos, bautismos, entierros y otros tipos de actividades. Cuando este chico llega a la adolescencia, se hacen visibles en él otras características del pícaro, como lo ilustra la siguiente cita: Apénas entra en la pubertad el mataperros, ya sabe muy bien cuales son las reuniones de los jugadores, siendo estos sus únicos compañeros. Sabe fincar los dados muy bien y conoce perfectamente el manejo de las cartas de pega y las de marca. Ninguno de los tenebrosos misterios del tahúr se le oculta: todos sus hábitos se los apropia; su solo oficio es unirse al que gana. (Los cubanos 316)

A partir de esta edad nuestro tipo se convierte en un parásito social que vive del vicio, en muchos casos huyendo de la justicia y que muchas veces termina convirtiéndose en un criminal, como sucede con El buscón. Algunos de estos tipos cubanos poseen entre sus rasgos característicos un carácter proteico. Es el caso de la coqueta (a quien identificamos con la pícara) del estudiante y del pica-pleitos. De la coqueta dice el autor que es una "engañosa flor que brinda mentidos 
perfumes y solo encierra en su cáliz indiferencia y egoísmo" (Los cubanos 7). Ella, como la pícara, tiene el afán de agradar al sexo opuesto, siendo "infatigable Proteo que toma todas las formas morales [. . .]" (8) para engatusar a sus pretendientes a los que no puede amar nunca de veras.

Por su parte, el estudiante, que se presenta en esta galería de personajes, tiene mucho en común con muchos de los estudiantes apicarados que conocemos a través de la literatura. No debemos olvidar que algunos pícaros fueron en algún momento de su existencia estudiantes. Por andarse en cafés y confiterías, llega tarde a clase o no llega nunca. Se le encuentra siempre en bailes y billares o garitos de juego. Cuando se halla en dificultades económicas se dedica a enamorar a jóvenes con dinero, y "para lances de amor es un Proteo en cuerpo y alma [. . .]" (Los cubanos 67).

La palabra pica-pleitos, con la que se denomina el siguiente tipo, "quiere decir: embustero que usa de tracamandería, enredo y trampa [. . .]" (Los cubanos 124), características todas pertenecientes al tipo del pícaro. De este personaje, que vive de la mentira y de la inocencia y candidez de los demás, el escritor nos dice que "se arrastra como la culebra para introducirse en las familias, tiene la astucia de la zorra, el olfato del perro, la humildad del cordero, el corazón del tigre, las garras del buitre y las piernas del galgo" (124). Como buen pícaro, el pica-pleitos 
"es un Proteo que se reviste de todas formas, él todo lo revuelve, todo lo vé, todo lo sabe, en todas parte se encuentra [. . .]" (126).

Uno de los tipos presentados en Los cubanos pintados por sí mismos que a nuestro juicio ofrece una mayor semejanza con el pícaro es el vividor o guagüero. Entre las características más evidentes del pícaro se encuentra el pragmatismo con que enfrenta la sociedad en la que le ha tocado vivir. Un vividor es un tipo que vive a cuenta de los demás, lo mismo que hace el pícaro. Al igual que el pícaro el vividor no se enfrenta a la sociedad, sino que mediante la trampa y el engaño, la astucia y la comicidad, trata de sacar ventajas de la situación. El vividor cubano se cuela en las casas con zalamerías, allí come, bebe y lee el periódico, sin haber sido invitado, y rechaza las invitaciones para hacerse desear. Es cliente fijo de cafés y confiterías donde nunca gasta de lo propio, porque con su comicidad y su gracia se gana los afectos y las invitaciones. Como buen pícaro, no se involucra en situaciones comprometedoras ni violentas, porque es cobarde, aunque esconde su cobardía con tretas. Tampoco se enamora, pero visita las casas donde hay ricas herederas y pone en juego sus atractivos para enamorarlas y casi siempre lo logra. Además de los tipos mencionados hasta ahora, el volumen de Los cubanos pintados por sí mismos, incluye algunos otros de rasgos apicarados, como son el corredor intruso, el tabaquero, el testaférrea y el litigante. Todos estos tipos son charlatanes, astutos, calculadores, 
viciosos que saben eludir la acción de la ley para conseguir sus objetivos. Muchos de ellos viven a cuenta de los demás y a ninguno de ellos le interesa cambiar la sociedad en que viven, sino sacar provecho de la misma.

No puede dejarse fuera de este estudio uno de los tipos que nos parece digno de señalar: el lechero, especialmente por ser, a diferencia de los antes mencionados, un tipo rural. Este personaje, que es en apariencias, "de costumbres inocentes, honrado y próbido... se convierte en cura y bautiza la leche [. . .]. Astuto por naturaleza, todo lo que le falta de letras le sobra de tretas" (Los cubanos 24). Este habitante de los campos cubanos, es uno de los más apicarados de nuestra sociedad, ya que "se arrastra como el majá y da mil vueltas, bajeando como aquel hasta que, casi sin esfuerzo, hace la presa deseada" (Los cubanos 24). Es el lechero otro personaje de nuestra sociedad que se ajusta a las circunstancias para sobrevivir por medio de engaños y trampas.

Hemos visto, pues, que en la sociedad cubana del siglo XIX aparece una tipología que fue el resultado de múltiples combinaciones de rasgos heredados de las distintas etnias que forjaron el estamento humano nacional. Algunos de estos tipos desaparecieron totalmente de la sociedad cubana republicana; otros solamente se transformaron y puede rastrearse su presencia en la narrativa cubana posterior. 
Notas

' Conviene recordar que debido a la presencia anglosajona se establecieron en Cuba las primeras logias masónicas de América Latina, y que es en ellas donde se urden las primeras conspiraciones para la independencia de la Isla.

${ }^{2}$ Fernando Ortiz resume en esta cita los juicios de una serie de escritores sobre el tema, entre los que se encuentran Paul Marie Victor Barret, Albert Reville, Charles Jean Marie Letorneau y Adolphe Luis Coreau.

${ }^{3}$ Como bien afirma el profesor Reinaldo Sánchez, "los tipos de [. . .] esa colección no guardan relación con una realidad genuinamente cubana. Son personajes universales, no locales o nacionales" (759).

${ }^{4}$ Se ha respetado la ortografía y acentuación del documento original.

${ }^{5}$ Estas eran como una especie de pandillas, que se asemejan a las germanías de pícaros como Rinconete y Cortadillo. 
Capítulo Tercero. Cuba: filosofía y literatura

Culturalmente, la Isla había iniciado su desarrollo antes de la instauración de la República. Tanto las tradicionales tertulias literarias, como la impresión de revistas y periódicos, datan de la época de la Colonia y los mismos continuaron, aunque ajustándose a las nuevas condiciones, durante la República.

1. Desarrollo de la cultura cubana

Como acertadamente comenta Raúl M. Shelton, la cultura se despliega en la creación y transformación del lenguaje, la literatura, el arte, la ciencia, la filosofía, la moral, el derecho, la sociedad y en el estado de sus instituciones políticas. La base material de la cultura es la economía, que constituye, conjuntamente con la política, una función cultural. (305-306)

Debido al hecho de que en los primeros años de la conquista, Cuba era solamente un punto de tránsito para las empresas conquistadoras y de que en gran parte, la isla vivía de una "economía pirática", las condiciones existentes no eran las más propicias para el desarrollo de la cultura. Esta situación se prolonga durante los siglos XVI y XVII, en que solamente existen unas pocas manifestaciones culturales, como es el inicio de la poesía con "Espejo de Paciencia". No sería hasta principios del XVIII, fecha de fundación de la Real y Pontificia Universidad de La Habana 
(1721), y de la introducción de la imprenta (1720), que se darían los primeros pasos en la afirmación de la cultura cubana, coincidentes, como señala Félix Lizaso, con "la aparición de una conciencia criolla" (12). Octavio R. Costa comenta que "hay que suponer que al comenzar la centuria existirían no pocos versificadores criollos [...]" (1: 35), pero aunque los poetas no fueron tan abundantes como se cree, los que hubo tampoco se preocuparon de que sus textos fueran conservados.

Francisco López Segrera es de la opinión que "en Cuba florece una cultura criolla, entre la segunda mitad del siglo XVIII y 1868 , proveniente de la intelectualidad orgánica de los dueños de plantaciones [. . .]. Esta cultura criolla se expresará, principalmente, a través del costumbrismo y el romanticismo" (38). En estos inicios de la cultura también es importante la presencia de los ingleses durante la toma de La Habana, ya que en los barcos que llegaban al puerto durante esa época venían libros sobre las ideas predominantes en Europa. La lectura de estos textos transformaría el incipiente pensamiento cubano, dando lugar a diferentes ideales de vida. Octavio R. Costa considera que a partir de este momento se hace definitiva la presencia del cubano, "[. . .] con su propia personalidad cubana, netamente diferenciada de la del peninsular" (1: 35). Aparecen en este período dos figuras de importancia en nuestra poesía: Manuel de Zequeira y Arango y Manuel Justo de Ruvalcaba. 
Como acertadamente comenta Raimundo Menocal, "antes de constituirse la Sociedad Económica, en 1793, en Cuba reinaban el atraso, la ignorancia y la pobreza y todo un cúmulo de propensiones a resistir la influencia de las ideas y tendencias que emanciparan al espíritu de prejuicios y supersticiones [. . .]" (1: 35). Fue durante la época del despotismo ilustrado de Carlos III, y bajo la administración de don Luis de las Casas, que en Cuba se empieza a notar un adelanto cultural. Se funda el Papel Periódico en 1790, y se crean la Real Sociedad Económica de Amigos del País (1792) y el Real Consulado de Agricultura y Comercio (1794). A partir de este momento surgen oportunidades para que sobresalieran cubanos que poseyeran facultades intelectuales y espíritu científico, como fueron el economista Francisco de Arango y Parreño y el médico Tomás Romay.

Nos parece acertado destacar la importancia que tuvo en todo este proceso inicial de la formación del pensamiento cubano el Real Colegio de San Carlos, fundado en 1768. Dicha institución "[. . .] se distinguió principalmente por el método liberal de enseñanza que adoptó. Su programa de estudios, que ya esbozaba un rompimiento con la filosofía escolástica, indudablemente engendró el espíritu especulativo y favoreció el cambio radical y profundo en la civilización cubana" (Menocal 1: 100). Fue en las aulas del San Carlos donde se formaron los pensadores 
cubanos responsables de llevar a cabo los cambios más progresistas en la cultura cubana del siglo XIX y principios del XX.

Aunque desde fines del siglo XVIII surgen ya, de forma coherente las primeras expresiones de la nacionalidad cubana,

[. . .] en las primeras décadas del siglo XIX, con la acumulación de capitales producto del llamado "boom" azucarero de 1790 , se conforman y consolidan las principales clases sociales que compondrán la sociedad colonial cubana de la primera mitad del siglo. La sacarocracia criolla, en la misma medida en que fue perfilando sus rasgos como clase poseedora dominante, fue creando sus propias instituciones culturales y sus peculiares maneras de expresión en el campo intelectual y artístico. (López 38-39) Algunos autores son de la opinión de que la cultura nacional surge en la Isla alrededor de 1880, "[. . .] porque es el momento en que, recién abolida la esclavitud, la formación nacional se acelera" (López 75). Son tiempos en que las corrientes realista y modernista se hacían presentes en todas las manifestaciones del arte y la cultura. Nuestra esencia nacional surgirá en el arte y el pensamiento de José Martí.

Una vez instaurada la república en Cuba, y con la crisis que representó la aceptación de la Enmienda Platt para algunos de los intelectuales cubanos, el desarrollo de la cultura nacional sufre un 
retroceso. Según López Segrera, en estos momentos de transición para Cuba, "los valores de la cultura nacional [. . .] quedaban circunscritos a las capas medias que [. . . ] serán los portavoces de la cultura nacional, aunque no nacional-popular [. . .]" (105). Prueba de la situación en que se encontraba la cultura cubana en esos momentos, aparece en visión de Fernando Ortiz: "La sociedad cubana se está disgregando. Cuba se precipita, rápidamente, en la barbarie" ("La decadencia" 71). También Jorge Mañach hace patente el estado crítico en que se encontraba la cultura en esos momentos al afirmar que "carecemos de ese alto y denodado esfuerzo, de esa briosa y heroica vocación a las labores más altas del entendimiento. Los Varona, los Aramburu, los Ortiz, los Guerra, los Chacón y Calvo, ¿no podéis contarlos con los dedos de una sola mano?" (30).

Durante esta época surgen publicaciones culturales importantes en las que expresaban sus preocupaciones e ideas los más destacados intelectuales del momento. Entre ellas, las más influyentes fueron la Revista Bimestre Cubana, la Revista de la Facultad de Ciencias y, sobre todo, Cuba Contemporánea. Fue en las páginas de estas revistas donde se expresó la honda preocupación por lo cubano y donde la protesta cívica contra los defectos y vicios de la joven república llegó a su más alta expresión. 


\section{A) El pensamiento cubano.}

En su obra Las ideas y la filosofía en Cuba, Medardo Vitier afirma:

La economía interna de las sociedades realiza siempre [. . .] una renovación gradual (o súbita, violenta) de los valores, que esencialmente son creencias, intereses [. . .]. La minoría responsable intenta cambiar los módulos de convivencia. Esos guiadores representan las corrientes últimas del pensamiento y de la acción; entroncan con la cultura universal a la vez que ponen oído al clamor del agregado social al que pertenecen [. . .]. Hay épocas orgánicas y épocas críticas. Las primeras, equilibradas disfrutan de relativa paz, construyen, creen en los soportes de su hechura; las segundas, juzgan agotada toda su savia vital y remueven, abaten, cancelan. (11-12)

Basándonos en la teoría expuesta por Vitier, podemos afirmar que hasta fines del siglo XVIII Cuba vive en una época orgánica, mientras que "[. . .] casi todo nuestro siglo XIX forma una época crítica, de pasos lentos, firmes, continuos" (Vitier 12). En lo intelectual, como toda civilización colonial, la cubana estuvo caracterizada por el predominio del escolasticismo que trajo consigo la ausencia de espíritu crítico y de sentido histórico y una fe casi absoluta en la autoridad aristotélica. Era 
necesario romper con esas ideas para iniciar una reforma del pensamiento nacional.

La fuerza alteradora inicial que comienza a forjar el pensamiento cubano es José Agustín Caballero (1762-1835), catedrático de filosofía del Seminario San Carlos, cuando en el año 1795 denuncia el atraso de la enseñanza y abiertamente rechaza el escolasticismo para adoptar la influencia agustiniana y eventualmente llegar a la línea de Descartes y a sus influencias posteriores. Ya existe en él un incipiente eclecticismo cuando dice: "[. . .] buscar la verdad sin jurar en las palabras de ningún maestro" (Citado en Vitier: 193). Su obra Filosofía electiva, primera obra de filosofía escrita en Cuba, es considerada por muchos estudiosos como una obra de capital importancia en el proceso de afirmación de nuestra nacionalidad y como uno de los pilares que sirvieron de base ideológica a la libertad de Cuba.

Los esfuerzos de Caballero por divulgar en Cuba las nuevas filosofías europeas (Bacon, Descartes, Galileo, Locke, Newton y otros) desempeñaron un papel importantísimo en el desarrollo del pensamiento cubano. En unos de sus escritos hace patente estas ideas al afirmar: "murió para siempre el horrísono escolasticismo en Europa [. . .] Entró en su lugar la antorcha de la verdad: el experimento" (1: 129). Gustavo Serpa observa que "la filosofía de Caballero está ligada a los comienzos de la época ilustrada; su actividad va desde la reforma de la enseñanza, la 
crítica del aristotelismo, la difusión de las nuevas ciencias naturales, hasta la presentación de un proyecto de autonomía para la colonia" (42). Fue gracias a las influencias de José A. Caballero que las clases conscientes de Cuba se empezaron a desvincular del tradicional oscurantismo que caracterizaba al régimen colonial, y con ese motivo surgió con relieves propios y definidos un pensamiento que, al concretarse, había de fijar, tanto en lo social como en lo político y económico, las normas que la sociedad cubana debía seguir a fin de realizar su mejoramiento colectivo. (Menocal 1: 165-166)

Por las aulas del Seminario San Carlos pasarían quienes fueran, cada una en su momento, figuras cimeras del pensamiento filosófico cubano del siglo XIX: Félix Varela (1787-1853), José Antonio Saco (17971879) y José de la Luz y Caballero (1 800-1862). Esta trayectoria filosófica cubana llegaría a su punto más elevado con la presencia de Enrique José Varona (1849-1933), a quien se considera como la figura clave del pensamiento cubano en el período de transición de la colonia a la república.

Las opiniones de los pensadores e historiadores cubanos sobre la significación histórica de la figura del Padre Félix Varela son de una gran variedad. "Para José de la Luz y Caballero fue 'el primero que nos enseñó a pensar'. Otros le han asignado el rol [. . .] de mentor de la juventud 
cubana o de precursor de la independencia" (Hernández, J.1).' Según reza la placa que aparece en el monumento de la Universidad de la Habana, fue "el Padre de la Patria". Hay quienes lo consideran como el forjador de la conciencia cubana o como el primer revolucionario.

La figura de Varela aparece en el panorama del pensamiento cubano en el momento culminante en que se trata de romper con el pasado inactivo y arcaico. Con Varela "empieza una nueva era para la sociedad cubana, y el pensamiento toma un vuelo y una orientación desconocidos hasta entonces [. . .]" (Menocal 1: 171). Siguiendo las enseñanzas de José A. Caballero y adoptando un cariz más radical en cuanto a su postura política, Varela rechaza las supervivencias escolásticas y comienza sus reformas, siguiendo la línea liberal "[. . .] de entronque agustiniano en que se situaba el Seminario" (Lizaso 21). Uno de sus grandes logros fue establecer el precedente de enseñar en castellano, aún sin ser oficialmente permitido por las autoridades españolas.

En el pensamiento inicial de Varela se juntan dos corrientes. Al racionalismo de Descartes hay que añadir el utilitarismo de Bacon. De esta manera, y como afirma Raimundo Menocal, "el Padre Varela se lanzó a impulsar el desarrollo del intelecto cubano [. . .]" (1: 173). Por su parte, Juan J. Remos es de la opinión que el padre Varela fue en los estudios filosóficos "un reformador valiente, desechando el escolasticismo y, 
dándole paso a las nuevas ideas sensualistas, al pensamiento empírico, afirmándose en la razón y en la experiencia" (Los forjadores 17).

El mérito del Padre Varela en el proceso del desarrollo del pensamiento cubano no radica en su originalidad, sino en el hecho de que fue el que expuso en Cuba nuevas doctrinas que tendían a "rectificar el espíritu de sus discípulos, poniéndolos en posesión de sí mismos y en completa aptitud de adelantarse, con provecho y sin trabas ni temor alguno, por el inmenso campo de la ciencia" (Rodríguez, J.I. 106).

A pesar de que hay quienes consideran a Saco como un continuador de las ideas de Varela, hay otros historiadores que señalan que ningún rasgo común los unió, al menos en lo que se refiere a su vida pública y confesada y en las influencias que el último haya podido tener en el primero. José Antonio Saco se destacó mayormente en el campo del pensamiento político; hay quien lo ha llamado "[. . .] el primer gran Político de nuestra historia" (Arroyo 11). Saco fue una figura mucho más polémica y sus ideas le granjearon la impopularidad entre sus contemporáneos, a pesar de que hoy en día se le considera como "[. . . el el planteador dialéctico de nuestra problemática nacional" (Arroyo 16). José Antonio Saco fue discípulo de Varela y su sustituto en la cátedra de Filosofía del Seminario San Carlos: "Continuando en la línea trazada por Varela, le dio, sin embargo, un carácter marcadamente político a sus enseñanzas [. . .]" (Lizaso 34). Saco fue antianexionista y 
abolicionista, y dentro de la evolución del pensamiento cubano, representa el acento político de mayor intensidad entre los hombres de su época. Sería el que difundiera las ideas del reformismo en toda extensión y profundidad, tanto en lo político como en lo social y cultural. Fue "partidario de alcanzar la independencia de Cuba por evolución y no por revolución" (Remos, Los forjadores 24). Entre las ideas más importantes de Saco se destaca la de que era necesario educar y preparar al pueblo, para que cuando Cuba alcanzara su independencia tuviera la capacidad necesaria para llevar a cabo todas las responsabilidades y funciones que requeriría el momento.

En la obra de José Antonio Saco se pueden diferenciar varios aspectos, aunque todos van dirigidos a un eje común: la mejora de las condiciones sociales en Cuba. Saco fue un hombre de ideas científicas modernas. Al igual que Varela, se aparta del escolasticismo y se convierte en "el hombre de ciencia positivista, primero de nuestros hombres ya modernos, de la nueva era del progreso científico" (Arroyo 115). Todo el pensamiento de Saco gira alrededor de dos grandes temas: la realidad cubana y sus problemas, y al estudiar estos temas se puede apreciar la evolución de su pensamiento en cuanto a las diferentes posturas políticas que sostuvo, ya que éstas siempre estuvieron entrelazadas a las sociales y educacionales. 
Aunque mal interpretado por muchos de sus contemporáneos, Saco fue un espíritu agorero, zahorí de nuestra historia política. Se adelanta a la "sabiduría política" de los autonomistas porque basa en la inmadurez del cubano su incapacidad para ser independiente; pero no se detiene ahí, él ve en aquélla un estado transitorio, una etapa histórica que tiene que ser superada cuando el cubano adquiera la conciencia de su nacionalidad. La idea de nacionalidad cubana late en el fondo de su pensamiento político constantemente; pero él sabe que ese estado de conciencia colectivo que supone aquélla aún no se ha producido. (Arroyo 133)

José de la Luz y Caballero es la tercera gran figura dentro del pensamiento cubano del siglo XIX. Ocupó la cátedra de filosofía del Seminario San Carlos que dejara vacante José A. Saco y continuó, hasta cierto punto, la tradición establecida años antes por su tío Agustín Caballero. Luz y Caballero poseía una sólida cultura humanística, así como gran saber filosófico y unas excepcionales dotes educativas. Desde el punto de vista pedagógico, era partidario del método experimental y combatió los métodos de memorización. Sin embargo, como muy bien afirma Medardo Vitier, "discernir las doctrinas que siguió en filosofía es cosa mucho más difícil" (373). Esto se debe en parte a la doble cualidad 
de Luz y Caballero de pensador y creyente que permea toda su obra. También es a veces difícil fijar su posición filosófica porque sus escritos sobre el tema son fragmentarios. Otra figura cumbre del pensamiento, Enrique José Varona dijo de Luz y Caballero que era "el pensador de ideas más profundas y originales con que se honra al Nuevo Mundo" (Citado en Vitier La lección de Varona: 34). La idea rectora del método que se manifiesta en la enseñanza filosófica en Cuba a partir de José $A$. Caballero, que también se observa en Varela, es patente en el pensamiento de Luz y Caballero.

El intenso espíritu patriótico de Luz y Caballero lo hace que se incline por los nuevos métodos de enseñanza, porque para él era importante para lograr la libertad de Cuba que el país afirmara la conciencia de su moralidad y de sus aptitudes. En una ocasión escribió: "Educar no es dar carrera para vivir, sino templar el alma para la vida" (Zayas 55). Según comenta Raimundo Menocal, "toda su filosofía gira alrededor del postulado de que es preferible mantenerse en la ignorancia, a que la instrucción sirva para avivar la maldad y la picardía" (1: 207).

La obra de Luz y Caballero refleja de manera casi constante una de sus grandes preocupaciones: formar y preparar a las generaciones venideras para que pudieran asumir la responsabilidad de dirigir la naciente sociedad cubana. Está claro que en su pensamiento estaban intimamente ligados el patriotismo y su amor a la enseñanza, pero una 
enseñanza que fuera útil a la patria, no la mera acumulación de conocimientos: "Nos proponemos fundar una escuela filosófica en nuestro país: un plantel de ideas y sentimientos y de método. Escuela de virtudes, de pensamientos y acciones; no de expectantes y eruditos, sino de activos y pensadores" (Zayas 55).

José de la Luz y Caballero representó un paso de avance en la corriente filosófica cubana. Si

el Presbítero Caballero y el Padre Varela engendraron el espíritu de especulación que propició el escepticismo, Luz y Caballero, con orientaciones más atrevidas y en consonancia con la libertad de la mentalidad cubana, calorizó la filosofía de la experiencia, momento que señala el paso del pensamiento cubano de su juventud a su madurez. (Menocal $1: 219)$

De los cuatro sistemas filosóficos que se manifiestan en la conciencia humana, es el sensualismo el que más concuerda con las doctrinas de Luz y Caballero. Era ésta la tendencia que mejor se ajustaba a la mentalidad cubana del momento, que, dominada por el espíritu utilitarista y el mercantilismo y carente de tradiciones de cultura, técnica e intelectual, solamente podría desarrollarse y progresar mediante el empirismo. 
En el pensamiento de Luz y Caballero se observa una evolución en la que se destacan tres etapas, cada una caracterizada en una dirección. Una religiosa, que fue su época de juventud; otra científica, que lo sitúa en el positivismo; y la tercera, la propiamente filosófica, en la que se dan cita una serie de ideas provenientes de la antigüedad clásica, sobre todo del aristotelismo, de la escolástica, de las teorías de Bacon, de Locke y de Kant a Hegel. Es la suya una filosofía ecléctica en la que se halla una aportación religiosa, una científica y una filosófica.

La trayectoria del pensamiento cubano llega a su punto culminante con Enrique José Varona, quien no solamente fuera, a juicio de muchos, el pensador que más influencia tuvo en el período de inicios de la república, sino una figura de gran importancia en la política de la época. Es Varona "quien inicia a Cuba en los nuevos rumbos del pensamiento positivista, a partir de 1880 [. . .]" (Remos, Los forjadores 54), hecho éste que le ha sido criticado por más de uno de nuestros escritores e historiadores, aunque en realidad ese positivismo es una reacción contra el escolasticismo colonial, el mismo contra el que ya habían reaccionado Varela y Caballero. Hay otros autores, como José Sánchez Boudy, que defienden el positivismo de Varona, afirmando que "no tomó de él ni la religión, ni la idea de la historia [. . .] ninguna en que se perdiera la espiritualidad. La aplicación del Positivismo en Cuba se concretó en un 
cientificismo. Se concretó en poner a Cuba al par de las naciones científicamente adelantadas" (104).

En realidad, el pensamiento positivista de Enrique José Varona parte de las influencias de Comte, y evoluciona más tarde hacia el pensamiento inglés representado por Mills, Spencer y Bain, pero sin dejar de circunscribirse al problema nacional. José Antonio Portuondo al comentar sobre Varona y su positivismo dice que fue:

un agudo auscultador de las circunstancias históricas, que en cada instante de su larga y fecunda vida dice la palabra precisa con bella y serena parquedad que se concreta, no pocas veces en aforismos. Él encarna, como ningún otro acaso, a toda una generación cuyo positivismo, mejor una actitud que una doctrina, significó el repudio de viejas metafísicas [. . . aliadas al despotismo y el nacimiento de un nuevo sentido realista y científico de la vida indispensable a la nación que iba forjándose [. . .]. (Bosquejo 33-34)

A pesar de que la obra de Varona comprende múltiples campos en las ciencias y en las artes, su consagración al bien de su país constituye también la permanente y honda preocupación de todos sus días, pudiendo decirse que sus investigaciones y sus estudios, desde los filosóficos y sociológicos hasta los históricos y 
pedagógicos, llevan como finalidad última y constante la de ser útil a sus conciudadanos y a su patria, la de laborar por el mejoramiento de la tierra en que había nacido [. . .]. (Roig 56)

En esa entrega a la causa de Cuba, vemos que el objetivo primordial de Varona era la formación de una nación partiendo de las ruinas dispersas que quedaban de la Colonia. Como muchas de las figuras que le precedieron, pensaba que uno de los aspectos más importantes para la solidez de la nueva sociedad cubana era la educación. Varona estaba consciente de que la mayoría de los males y vicios de la naciente sociedad republicana tenían su origen en la Colonia, y que el problema no era solamente político, sino también que era primordialmente social. Para resolver estos problemas era necesario una reforma en la educación y es ahí donde aboga Varona por las tendencias positivistas. A juicio de Varona, la enseñanza en Cuba debía sufrir una drástica transformación, puesto que el sistema caduco de la colonia no preparaba a las generaciones futuras para el progreso de la nación. La inclusión de las ideas positivistas, especialmente en el campo de las ciencias, ayudaría al avance del país.

Se ha comentado que Varona fue pesimista, sobre todo al enjuiciar la situación cubana durante los primeros treinta años de República. A nuestro juicio, su visión no era pesimista, sino realista y sincera. Varona 
se atrevió a señalar los males sociales que se originaron en la época colonial y que caracterizaron nuestros primeros años republicanos, los mismos que criticarían en su obra literaria los escritores cubanos de la primera generación republicana. Varona enjuicia duramente la supervivencia colonial en la República:

Han vuelto al asalto de la administración pública la incompetencia, el favor, el nepotismo, la corrupción. Hay quienes resisten, pero hay quienes flaquean y hay quienes se rinden. Hemos envenenado la fuente misma en que debíamos beber la salud. Se pone la pequeña administración de la justicia, que está más en contacto cotidiano con el pueblo, en manos que entorpece la ignorancia, cuando no las tuerce el interés. Se proclama la intangibilidad de lo mal adquirido. $Y$ así se emponzoña la conciencia pública, porque se nos hace desconfiar del esfuerzo del trabajo; y se pone sobre el pavés al afortunado, cualquiera que haya sido el origen de su fortuna, la vara de Midas que ha hecho brotar su corriente de oro. Ya no hay necesidad de aguardar la nave que nos llevará a tierra distante con nuestras arcas repletas. En los lugares más pintorescos de los alrededores o en el corazón mismo de la ciudad bulliciosa se levantan los palacios de aquéllos a quienes la suerte pródiga ha mirado 
con ojos risueños y ha descubierto el secreto de la fortuna improvisada. El mísero sin pan lo saluda con secreta envidia, y va a comprar la fracción del billete que le promete falazmente, por otro camino, la misma suerte deslumbrante [. . .]. Nuestro triste pasado se ha erguido de súbito, para lanzarnos al rostro que en vano hemos pugnado, nos hemos esforzado y hemos sangrado tanto. La generación de cubanos que nos precedieron y que tan grandes fueron en la hora del sacrificio, podrá mirarnos con asombro y lástima y preguntarse estupefacta si éste es el resultado de su obra, de la obra en que puso su corazón y su vida. El monstruo que pensaba haber domeñado resucita. La sierpe de la fábula vuelve a reunir los fragmentos monstruosos que los tajos del héroe habían separado. Cuba republicana parece hermana gemela de Cuba colonial. (Citado en Roig: 59-60) ${ }^{2}$

Para concluir, podemos afirmar que el pensamiento cubano estuvo caracterizado, prácticamente desde sus inicios, por un rechazo al escolasticismo que predominaba en las colonias y por una tendencia hacia el eclecticismo. Cada uno de nuestros grandes pensadores, trató de incorporar las nuevas ideas que iban surgiendo en los países europeos más adelantados, pero sin apartarse del ámbito nacional. En otras palabras, desde Varela a Varona, se observa una preocupación por el 
problema cubano. Las ideas que iban adoptando de otras filosofías les servían de base para intentar resolver los problemas económicos, políticos y sociales que enfrentaban los cubanos en los tiempos de la lucha contra la metrópoli y la instauración de una república independiente y soberana.

\section{Trayectoria del discurso narrativo cubano desde sus orígenes hasta} 1933.

La narrativa cubana se inserta profundamente en el proceso histórico que ha sufrido el país, y ello será reflejado por los narradores de cada período. Afirma Manuel Pedro González que "la literatura cubana [. . . ] es un producto del siglo XIX y se inicia con la era revolucionaria [. . .], surge paralela y simultánea con la idea de independencia y el concepto de nacionalidad política. ("Literatura" 73). También Jorge Ibarra hace referencia a esta relación, cuando afirma que la novela, especialmente la realista y la naturalista son "[. . .] un espejo que reflejará las pasiones y la preocupaciones de una época" (42).

Por su parte, Raimundo Lazo en su Historia de la literatura cubana señala varias épocas que facilitan el estudio de la literatura cubana. Cada uno de estos períodos está relacionado de forma paralela con un período de la historia de Cuba, y los clasifica de la siguiente manera: "período de antecedentes o de la Factoría colonial (1492-1790); período de la 
integración de la Colonia, o de la transformación de la Factoría en Colonia, [. . .] o período colonial avanzado (1790-1902); y período de la República o de la búsqueda de la consolidación de la independencia política y de la autonomía económica y cultural, desde 1902 [. . . ]" (18). ${ }^{3}$ Lazo subdivide en período colonial en tres momentos: de la transformación material de la Factoría en Colonia (1790-1834); de la integración de la Colonia (1834-1868) y la de la transformación de Colonia en República (1868-1902). Es precisamente durante la época de la integración de la Colonia, donde empiezan a surgir las primeras manifestaciones de la prosa narrativa cubana.

\section{A) La prosa narrativa antes de 1902.}

Si se compara con otros géneros, como la poesía lírica, la narrativa cubana surge tardíamente. Aunque si bien es cierto que a partir de la fundación del Papel Periódico en 1790, empiezan a publicarse algunos cuadros de costumbres, en los que, según Salvador Bueno, "[. . .] advertimos genuino material novelesco" (171), no es sino hasta los momentos en que el romanticismo se halla en pleno apogeo (entre 1830 y 1840) cuando se inicia una mayor producción de prosa narrativa entre los escritores criollos. Los eruditos señalan como primera manifestación novelesca en Cuba los Cuentos Orientales de José M. Heredia (18031839), que fueron publicados en el año $1829 .{ }^{4}$ 
No es hasta ya entrada la época que Lazo llama "de transformación cultural" (a partir de 1834) que aparecen los primeros textos novelísticos. Es una época "de tensión creciente, de recrudecimiento del gobierno despótico colonial, de aumento del mercantilismo corruptor, de comercio clandestino de esclavos, de atropellos oficiales, y demandas cubanas de libertad y mejoramiento social, contestadas con negativas y violentas represiones" (Lazo, Historia 74). Son éstas las condiciones socioeconómicas y políticas que motivan el surgimiento y el rápido desarrollo de la narrativa cubana.

En realidad, y como señala acertadamente Max Henríquez Ureña, "la novela no hace su aparición en Cuba hasta el momento en que imperó el romanticismo" (1:226). Es el año de 1837 el que marca en Cuba el inicio de la producción novelesca, con Matanzas y Yumurí, de Ramón de Palma y Romay (1812-1860), que tiene el mérito de ser la primera narración cubana de tipo indigenista. Al año siguiente, se publican en $E I$ Álbum dos novelas cortas de este autor: El cólera en La Habana y La pascua de San Marcos, y en 1845 aparece El Ermitaño del Niágara. También en el año 1837 se dio a conocer como narrador Cirilo Villaverde (1812-1894), con algunas narraciones breves que inician el género del cuento cubano, y que fueron publicadas en la revista literaria $L a$ Miscelánea; en 1838 publicó algunas narraciones más en la revista $E$ I Álbum, y para 1839 aparece la primera parte de la que se considera la 
mejor novela del realismo costumbrista en Cuba: Cecilia Valdés. ${ }^{5}$ Otros novelistas de la época son Anselmo Suárez y Romero (1 81 8-1878), autor de la primera novela abolicionista americana, Francisco, ${ }^{6}$ José Antonio Echeverría (1815-1885), que inicia la novela histórica con Antonelli (1839), Gertrudis Gómez de Avellaneda (1814-1873), autora de varias novelas, entre ellas una de corte antiesclavista, $S a b(1841),{ }^{7}$ y dos novelas históricas Espatolino (1844) y Guatimozín (1846), y Félix Tanco Bosmeniel (1797-1871), autor de una obra titulada Escenas de la vida privada en la Isla de Cuba, que se componía de una serie de cuadros, tomados de la realidad. De estos cuadros solamente se ha conservado uno, Petrona y Rosalía. ${ }^{8}$

Un elemento digno de consideración en la narrativa de la época es el cuadro de costumbres. Casi simultáneamente con el surgimiento de la novelística en Cuba encontramos la aparición del cuadro costumbrista o del artículo de costumbres, que como comenta Max Henríquez Ureña tuvo gran influjo "[. . .] sobre la ficción narrativa cubana" (1: 226). Señala Raimundo Lazo que "la narración de muy vario carácter y valor que tiene por materia costumbres vigentes abunda de tal modo en esta época que es uno de sus típicos elementos fundamentales" (Historia 127).

Es a partir del año 1838 que se comienzan a publicar, en la revista La Cartera Cubana, los artículos de costumbre de José V. Betancourt (1813-1875), recogidos más tarde en un solo volumen. En 1847, José 
María Cárdenas y Rodríguez publicaría, bajo el seudónimo de Jeremías de Docaranza, su colección de artículos de costumbres titulada Colección de artículos satíricos y de costumbre, que habían sido previamente publicados en revistas españolas y traducidos al francés. ${ }^{9}$ Otro costumbrista cubano es Gaspar Betancourt Cisneros, más conocido como El Lugareño, que dio a conocer su obra Escenas cotidianas en la Gaceta de Puerto Príncipe, entre los años 1838 y 1840 . De una etapa posterior, data la obra de Luis V. Betancourt (1843-1885), en la que se percibe, a juicio de Salvador Bueno, "[. . .] la protesta, el afán moralizador, la vigorosa censura a la sociedad [. . .]" (189) en los tiempos que preceden al inicio de las luchas por la independencia.

A partir de la segunda mitad del siglo XIX se observa una gran abundancia de producción narrativa. Algunos notables novelistas de esa época son: Ramón Piña (1819-1861), autor de dos novelas Jerónimo el honrado (1 857) e Historia de un bribón dichoso (1860), esta última una novela psicológica de rasgos picarescos; ${ }^{10}$ Esteban Pichardo y Tapia (1799-1879), autor de El fatalista (1866), una novela cuyo elemento diferenciador es pintar costumbres cubanas arcaicas; y José R. de Betancourt (1823-1890) autor de una sola novela, Una feria de la Caridad en 183... (1856), un "[. . .] reflejo magistral de la vida cubana en la década de 1835 a 1845" (Remos 2: 199). 
Entre los años 1868 y 1895 , "el proceso de la literatura cubana se diferencia [. . .] del que sigue la literatura general de Hispanoamérica" (Lazo, Historia 148). Los dos períodos de guerra, separados por una paz pactada y por algunos no deseada, fue el marco propicio para que surgiera una novela "[. . .] de realismo satírico y descriptivo que hace blanco en el corrompido régimen colonial, aunque, por su estructura y ciertos recursos y tonalidades, continúa siendo romántica; el cuento, no muy abundante, tiende a lo sentimental o a lo filosófico" (Lazo, Historia 178). En el período que transcurre entre el Pacto del Zanjón (1878) y el inicio de la segunda guerra de independencia (1895), se observa un reflorecimiento de la novela en Cuba en el que abundan distinguidos autores que se ocuparon de cultivar la prosa imaginativa. Se observa, en muchos de estos novelistas, un mayor cuidado de la técnica y de la estructura, si se compara con los autores de la época anterior.

Entre los novelistas de este momento está Nicolás Heredia (18521901), considerado por algunos historiadores como la más alta representación de la novela de esa época. Su primera novela, Un hombre de negocios (1882), es, a juicio de Lazo, "un caso de narración convencional que [. . . ] muestra tanto cierta impericia y los efectismos de la novela folletinesca como anticipos de buena observación de su mejor obra posterior" (Historia 178). Leonela (1893), la segunda novela de 
Heredia es una novela realista, de ambiente cubano donde desfilan una serie de personajes criollos que ayudan al autor a crear una pintura "[. . . ] animada, minuciosa y veraz" (Lazo Historia 178), elemento de mayor valor en sí que la estructura y la trama de la narración. También sobresale en este período Tristán de Jesús Medina (1833-1886), cuya novela breve Mozart ensayando su Réquiem (1881), formaba parte de una colección de relatos titulada Cuentos de un diletante. El valor de la obra de Medina, según Lazo, radica en que se caracteriza por "[. . .] la inserción de un nuevo tipo de fantasía y de estilo en el relato imaginativo romántico" (Historia 181), característica que se anticipa a tendencias posteriores, como el modernismo. Por su parte, José Martí (1853-1895) también incursionó, quizás por casualidad, en el mundo de la novela, por la cual según él mismo confiesa, no sentía mucha inclinación." Amistad funesta (1885) fue la única que escribió, a petición de una amiga, y apareció publicada por entregas en el periódico El Latino Americano de Nueva York con el seudónimo de Adelaida Ral. La prosa de esta novela martiana, en opinión de Remos, "[. . .] es una avenida hacia el modernismo [. . . ] por su simbolismo y por el esmalte de sus colores [...]" (Historia 3: 42).

Es importante destacar que la experiencia de la guerra de 1868 se percibe en la mayoría de los narradores de las dos últimas décadas del siglo XIX. Es una narrativa donde el autor dirige su crítica a la realidad 
nacional. Estudiosos de la literatura cubana como Juan J. Remos y Raimundo Lazo, entre otros, coinciden en señalar a Ramón Meza (18611911) como el mejor novelista de la época; algunos lo inscriben en la corriente realista y señalan que en sus novelas describe costumbres de la época y penetra en la psicología de algunos tipos de la sociedad del momento; otros, sin embargo, afirman que en su narrativa aún se dejan sentir las huellas de Villaverde. Meza es autor de dos novelas cortas, Flores y calabazas (1886), en la que se percibe la influencia de María, del colombiano Jorge Isaacs, y El duelo de mi vecino (1885). Es en su novela Carmela (1886) donde más se nota la influencia que ejerció Villaverde sobre Meza. Algunos críticos piensan que Carmela era una hermana menor de Cecilia Valdés, aunque con no pocos atractivos. ${ }^{12}$

De toda la producción novelística de Meza, es Mi tío el empleado (Barcelona, 1887), la obra que le ha ganado más fama. En ella predomina el elemento satírico, utilizado especialmente para criticar al empleado español, que con poca o ninguna preparación para desenvolverse en cualquier tipo de cargo, se dedica a trepar hasta llegar a las más altas posiciones. Max Henríquez Ureña opina que en esta obra "no hay resquicio alguno para episodios sentimentales, ( $y$ en ella se) pone al descubierto el tortuoso mecanismo de una vida administrativa en la que imperan el fraude y el enriquecimiento ilícito" (2: 171). Es la sociedad que pinta Meza un "[. . .] reflejo fiel de la triste verdad de aquella 
administración corrompida e impía" (Remos, Historia 2: 570), existente en los últimos años de la dominación colonial. Don Aniceto el tendero (Barcelona, 1889), otra de sus novelas, "describe iguales combinaciones y trapisondas en el mundo de los negocios y refleja un ambiente sórdido, dentro del cual todo sentimentalismo muere de asfixia" (Henríquez Ureña 2: 171).

También se destacan en esta época finisecular Francisco Calcagno (1827-1903), que cultivó, entre otros géneros, la novela antiesclavista con Romualdo (1881), y la de corte científico con una narración sobre el origen del hombre que lleva por título En busca del eslabón (1888); Francisco Puig y de la Puente (1839-1911) autor de numerosas novelas románticas y abolicionistas publicadas entre 1856 y 1884 , siendo $L a$ Campana del Ingenio, a juicio de Remos, la más notable de todas; José de Armas y Céspedes (1834-1900), cuya novela Frasquito (1894) pertenece a la corriente de la novela histórica; Antonio Zambrana (1846-1922), autor de El negro Francisco (1 873) que continúa el género abolicionista de la obra Francisco de Suárez Romero, y Martín Morúa Delgado (1856-1909), quien, según Raimundo Lazo, "trató de llevar el naturalismo de Zola a novelas de tesis" (Historia 180) como Sofía (1891) y La familia Unzúazu (1901). 


\section{B) La primera generación republicana.}

La narrativa cubana finisecular y de los primeros treinta años republicanos está estrechamente ligada a las circunstancias históricas, políticas, económicas y sociales de la época, ya que se produce en un período histórico marcado por dos de los hechos políticos más significativos de la historia cubana del primer tercio del siglo XX: la instauración de la República (1902) y la caída de la dictadura del general Gerardo Machado (1933). La principal preocupación de los escritores de este período era la situación por la que atravesaba el país, y en sus obras puede observarse una postura crítica y una gran sensibilidad a los problemas que enfrentaba la naciente sociedad cubana. No cabe duda de que

la novelística de aquella época no sólo fue un espejo para las generaciones posteriores, sino que lo fue también para los hombres de aquellos primeros años que se vieron reflejados a la luz cruda de sus propias pasiones y vicios. La función crítica de nuestros primeros novelistas del siglo XX, consistió precisamente en acercar este espejo a la sociedad de su tiempo. (Ibarra 53)

Como acertadamente afirma Sarah Marqués, "la corriente moralista que nutre hasta entonces la novela cubana también alimenta a esta generación" (45). Los narradores de esta época, muchos de ellos nacidos 
entre los años 1875 y 1890, estaban "preocupados por la problemática cubana y empeñados en llevar a cabo reformas sociales, llamando la atención, por medio de sus obras, hacia los problemas que afectan la nación" (Marqués 45).

La narrativa que se produce en Cuba durante el período que abarcan los años de 1902 a 1933 se sitúa, en su mayoría, "dentro de los procedimientos realistas propios de la novelística española de fines del siglo XIX" (Bueno 353). En algunos de los autores, sin embargo, se advierten "[. . .] ciertas influencias de los narradores franceses finiseculares" (Bueno 353). Dentro de estos parámetros existieron novelas históricas, entre las cuales destacan Vía Crucis (1910) y Doña Guiomar (1916) de Emilio Bacardí (1844-1922), y La insurrección (1910), la única novela de Luis Rodríguez Embil (1879-1954); novelas políticas, enclavadas en el marco histórico, como Sombras que pasan (1916), Ideales (1918) y Sombras eternas (1919), de Raimundo Cabrera (18521823): ${ }^{13}$ Humberto Fabra (1909), Coaybay (1927) y Las impurezas de la realidad (1931), de José Antonio Ramos (1885-1943); y algunas de las de Carlos Loveira (1 882-1928), como Generales y doctores (1920). Dentro de la corriente satírica, destacó Luis Felipe Rodríguez (1888-1947), "que se adentra con pie firme en la psicología de nuestra sociedad y nuestros hombres" (Remos, Historia 3: 286) en Cómo opinaba Damián Paredes (1916). También hubo una novela de índole científica, representada por 
dos obras de Juan Manuel Planas (1877-1963): La Corriente del Golfo (1922) y Flor de manigua (1926).

Juan J. Remos destaca en su Historia de la literatura cubana, un grupo de narraciones a las que clasifica como novela verista. Entre los autores mencionados se encuentran: Miguel de Carrión (1875-1929), Jesús Castellanos (1879-1912) y Carlos Loveira (1 882-1928). Otros novelistas importantes de la época, que se hallan cronológicamente fuera de los límites generacionales son Emilio Bobadilla (1862-1921), que publicó una de sus obras más famosas, A fuego lento en el año 1903, y Lino Novás Calvo (1905-1983), mucho más joven que el resto de los narradores, pero cuya biografía novelada Pedro Blanco, el negrero fue publicada en el año 1933.

También entre los años de 1902 y 1933, fueron cultivados en abundancia la novela corta y el cuento, tanto el lírico, de rasgos modernistas, como el de corte social. Entre los representantes más significativos de esta narrativa, hay que destacar Cuentos Pasionales (1907) y Novela erótica (1909) de Alfonso Hernández Catá (1885-1940), Gil Luna, artista (1908) y La mentira vital (1920) de Luis Rodríguez Embil, donde predomina "la nota íntima, el comentario lírico y la inquietante interrogación frente al destino y al misterio de la vida" (González "Literatura" 79); De tierra adentro (1906) de Jesús Castellanos (1879-1912), donde se observa la influencia francesa, especialmente la 
de Maupassant; Novelas de espumas (1906) de Miguel Angel de la Campa; y El Renuevo (1929) de Carlos Montenegro (1900-1981), uno de los cuentistas más jóvenes de la época. Entre los mejores cultivadores del cuento realista campesino se destaca Luis Felipe Rodríguez (1888-1947), que retrata con originalidad y de manera auténtica, la vida rural cubana en La pascua de la tierra natal, publicado en 1927, y Relatos de Marcos Antilla (1932). 
Notas

'José de la Luz y Caballero escribió "nos enseñó en pensar", y no a pensar como se lee en la cita de Hernández. Lo importante para Varela era en qué pensar.

${ }^{2}$ Estos fragmentos pertenecen al discurso de recepción en la Academia Nacional de Artes y Letras, pronunciado el 11 de enero de 1919.

${ }^{3}$ Raimundo Lazo cierra este último período en el año 1966, fecha de la primera edición de su Historia de la literatura cubana.

${ }^{4}$ Estos cuentos que son adaptaciones del francés, fueron publicados en México, en el periódico crítico-literario La Miscelánea, y aparentemente fueron muy poco conocidos en Cuba (Bueno 172).

${ }^{5}$ Villaverde terminó la obra en 1879 , y la versión definitiva no se publicó hasta 1882.

${ }^{6}$ La novela de Suárez Romero circuló manuscrita entre los amigos de la tertulia de Domingo del Monte, pero no se imprimió hasta 1880, en Nueva York.

'Raimundo Lazo es de la opinión que Sab es más bien "un romántico embellecimiento de un esclavo" (90) que un relato antiesclavista.

${ }^{8}$ Esta obra, aunque fue escrita en 1838 , estuvo inédita hasta 1925 , año en que fue publicada en la revista Cuba Contemporánea.

${ }^{9}$ Salvador Bueno señala que a Cárdenas se le conocía como "el Mesonero Romanos de Cuba" (187).

${ }^{10}$ Juan J. Remos destaca el parecido de algunos personajes secundarios con los pícaros cervantinos Rinconete y Cortadillo (206-207).

"Juan J. Remos en el tercer volumen de su Historia de la literatura cubana cita un texto martiano donde el autor expresa claramente que la novela moderna no le place.

12 Según Juan J. Remos, fue Varona el que hizo esta comparación entre ambas novelas.

${ }^{13}$ Loló de la Torriente Ilama a Cabrera "el escritor romántico de la ilusión republicana" (270). 
Capítulo Cuarto. Personajes picarescos en la narrativa de Jesús

Castellanos.

Jesús Castellanos y Villagelieu (1879-1912) es considerado por

numerosos críticos como la figura más prometedora dentro de la novela y el cuento entre los escritores que sobresalen en el período republicano que se marca entre 1902 y 1933 (Bueno 356). Debido a su temprana muerte, la obra de Castellanos es muy breve: la forman una colección de trece cuentos titulada De tierra adentro (1906); dos novelas cortas, La Conjura (1908) obra con que ganara los Juegos Florales habaneros, y que fue publicada en el mismo volumen con otras narraciones, La manigua sentimental (1909), otras narraciones sueltas que fueron publicadas póstumamente, y Los argonautas (1916), novela inconclusa debido al fallecimiento del escritor.

El estilo de Jesús Castellanos se sitúa entre el realismo, el naturalismo y el modernismo. Más cerca de las influencias francesas que de las españolas, en su obra se observa un germen derrotista que probablemente adoptó de los novelistas naturalistas franceses finiseculares. Usa las técnicas de Guy de Maupassant, Anatole France y Eça de Queiroz y la filosofía de Nietzsche se hace sentir fuertemente en toda su obra. Sin embargo, a pesar de todas estas influencias europeas, Castellanos es el primero que se interesa en dar expresión en el cuento a realidades autóctonas, como se observa en las narraciones que 
componen De tierra adentro. En los cuentos de esta colección, en su mayoría de temas universales, el autor narra, dentro del ambiente rural cubano, situaciones en las que está presente el campesinado.

Filosóficamente, también se advierte en Castellanos, la influencia arielista y proteica de Rodó.

\section{La conjura.}

La novela La conjura tiene como argumento principal la vida de un joven médico, Augusto Román, a quien su idealismo lo lleva a enfrentarse a una sociedad materialista, llena de convenciones sociales que obstaculizan sus más caros ideales. Es éste un relato donde se observan tendencias modernistas, y donde se nota la influencia de las ideas neitzscheanas.

Aunque, en general, la obra de Castellanos no ha sido objeto de la crítica, y algunos de los que le han dedicado algún trabajo, lo han hecho desde una óptica marxista, existen, en algunas obras de carácter general sobre la literatura cubana, juicios sobre el protagonista de la novela que nos ocupa y que, en nuestra opinión son, en ocasiones, contradictorios. De Augusto Román dice Salvador Bueno que: "es un abúlico, lleno de pesimismo [ . . .] (que) se inclina demasiado a la vida fácil [ . . .]" (356), mientras que Max Henríquez Ureña advierte que el personaje " [. . .] es un idealista que amamanta altas ambiciones de bienestar social, y es la 
sociedad misma la que lo constriñe y oprime, y hace imposible sus mejores empeños [. . .]" (2: 340-341). Si tomamos en cuenta las opiniones anteriores, nos queda la duda de si en realidad es el personaje un antihéroe que busca un acomodo fácil, y el sufrimiento y la frustración se deben al choque con la sociedad que demanda el esfuerzo del ser humano, o si es un personaje digno de encomio, que es víctima de una sociedad que lo limita, impidiéndole realizar sus más nobles ideales.

Al llevar a cabo una lectura de la obra a partir de la tipología que se presenta, y tomando en cuenta los diferentes rasgos, posturas y acciones que han caracterizado a los personajes picarescos, se observa que muchos de los de La conjura muestran a través de la narración, un comportamiento y una filosofía de vida que los acerca al pícaro tradicional, si bien adaptados y desenvolviéndose en una sociedad totalmente diferente.' En algunos casos, el personaje aparece como un héroe que trata de ser diferente al resto; sin embargo hacia el final de la narración lo vemos cediendo ya a las presiones de una sociedad que le es hostil y termina también apicarándose, para poder de esta manera lograr sus metas; en otros, desde el inicio mismo de la narración, el lector percibe ya una tendencia al comportamiento acomodaticio, proteico, que lo lleva a relacionarlos con el pícaro. Un tercer tipo es el personaje que, perteneciendo a las esferas más altas de la sociedad, no tiene necesidad de un comportamiento picaresco para sobrevivir, pero sí 
predica la filosofía del pícaro, aconsejándoles a otros personajes que se sometan a ciertos patrones, aunque estén en contra de sus ideales, para lograr llegar a ser alguien. Un último tipo es el personaje que lucha y nunca cede; prefiere el fracaso antes de caer en el juego que le propone una sociedad corrupta. Tras este personaje se esconde la filosofía del desengaño, tan ligada al discurso picaresco.

El ejemplo más notable del primer caso lo tenemos en el protagonista de la obra, Augusto Román. Este personaje, íntimamente ligado al título de la novela, puesto que en varias ocasiones hace alusión al hecho de que en la sociedad en que se desenvuelve existe una conjura para no dejar progresar a los individuos como él, deja ver cómo la nueva sociedad cubana le niega a la juventud las oportunidades para realizar sus sueños.

La conjura que da título a la obra es, en realidad, el resultado de la combinación de una serie de factores socio-económicos y políticos que obstaculizan el camino de Augusto, y la única manera de tener éxito frente a ella es el apicaramiento. El primer encuentro que tiene el lector con Augusto Román se realiza cuando éste regresa a su casa después de visitar a su tío (un ministro) con el propósito de "suplicarle una tarjeta para [. . . el el Secretario de Instrucción Pública" (La conjura 131). Así, desde el comienzo de la narración, el lector puede advertir que Augusto necesita de alguien con influencia para poder lograr sus objetivos, que si 
bien son ideales puros, requieren que se tenga una fuente de ingresos. En aquella sociedad solamente la persona que tenía las influencias apropiadas podía conseguir ciertos privilegios. Al personaje, aunque en apariencia, un ser de propósitos honrados y nobles, no le queda otro recurso que ir por el camino del pícaro: "arrimarse a los buenos" para sacar partido. ${ }^{2}$

La condición de Augusto de hombre acorralado por una sociedad que obliga a hacer una decisión entre adoptar una actitud decorosa, con la frustración de las metas irrealizadas, y claudicar ante las presiones y convertirse en un pícaro para lograr sus planes, se ve claramente en la opinión que de él tiene su tío: "un oso malamente enjaulado que saludaba a medias en la calle, hablaba horrores de la Academia, no asistía a los Años Nuevos de Palacio, mantenía públicamente una querida y llenaba su zaguán de la más haraposa clientela que se pudiese soñar para un congreso de mendigos [. . .]" (La conjura 131-132). Esta opinión de don Próspero Villarín nos parece clave para enjuiciar la imagen que del personaje tiene la sociedad. ${ }^{3}$ A juicio nuestro, Augusto rompe con todos los patrones establecidos por la misma para triunfar. La cita proyecta a un Augusto antisocial, crítico acérrimo del academicismo imperante, inmoral y sin conciencia de diferencias entre las clases sociales.

Sin embargo, esta imagen está en oposición con la que de sí mismo tiene el personaje, que se ve 
en el vigor, ya medio combatido, de los treinta y cinco años; erguida la testa bondadosa sobre el vasto corpachón, que habría sido hercúleo si el estudio y el insomnio no hubieran dejado en seco la amplia osamenta. Lacio el bigote, dormía sobre la arruga amarga de la boca, y con ambos armonizaban las manos, unas manos flacas, exangües, vestidas de floja piel, hechas para acariciar humildemente o para curiosear sutiles entre los libros; manos que, rendidas ahora sobre los brazos del sillón, decían todo el poema de aquel espíritu dulce y simple. Sólo en lo sumo de la pobre figura rompían con el cuadro de abandono dos ojos de fiebre, alocados, turbadores, bajo una frente de marfil viejo [. . .]. (La conjura 135-136)

Es interesante notar que esta visión lleva ya las semillas de un desengaño, de una amargura, de una derrota que se representan por la debilidad de las manos. Solamente los ojos conservan un poco de la llama que arde en su interior y que lo lleva al enfrentamiento social. Se presiente, sin embargo, que Augusto se encuentra al borde de sus fuerzas y que muy pronto cederá a las presiones. El texto implica el inicio de un proceso de apicaramiento, puesto que Augusto, como la mayoría de los pícaros, tiene que enfrentarse a una sociedad "donde le era difícil la existencia, donde se le imposilitaba el vivir [. . . ]" (La conjura 132). Las 
circunstancias que rodean al personaje al inicio del relato determinarán, a medida que avanza la trama, una actitud cada vez más picaresca frente a la realidad que confronta.

Además de las presiones sociales, influyen sobre Augusto los consejos y el comportamiento de dos personajes que a cada momento lo arrastran hacia una forma de vida apicarada: Próspero Villarín y Joaquín Morell. En un intento por mantener la cordialidad con su tío, y para no disgustar a su prima, Augusto finge y hace el papel que le corresponde en la sociedad cuando visita la casa de los Villarín. Empieza así un comportamiento proteico de amoldarse a las circunstancias, pero aún sobreviven en él ideales puros. Cuando se le ofrece un puesto de "superintendente de inspectores sanitarios", lo rechaza asqueado de ver que para don Próspero lo importante sólo es el dinero y las ventajas que puede traer ostentar ese puesto en momentos de importancia política.

Cada uno de los ofrecimientos que don Próspero le hace a su sobrino, está basado en la premisa de que cambie su forma de vida. El último de ellos es la dirección de un hospital, una plaza que le permitiría continuar sus investigaciones científicas. Sin embargo, don Próspero le advierte:

[. . . ] esto es a condición de que cambies tu vida [. . .], a que te vuelvas un hombre tratable y con aspiraciones, a que rompas con todo lo que hoy te estorba y entres en la 
sociedad que debes estar... [. . .] la entrada en el hospital te impone la ruptura con esa muchacha [. . .] tienes que consolidar tu situación. Tienes que casarte cuanto antes... [. . .] Para presentarte en sociedad acompañado de una mujer elegante no se necesita buscar mucho... Así andan por ahí los buenos partidos... (La conjura 178-179)

Por su parte, Morell, como abogado y amigo de Augusto, no cesa de hacerle ver las conveniencias de aceptar las reglas del juego social. Cuando Augusto decide presentarse a unas oposiciones para una cátedra, su amigo comenta que hay algunos intereses entre los miembros del tribunal que no le favorecen:

[. . .] parece que en el claustro están de uñas con tu tío por no sé qué crédito que no ha querido aprobarles... [. . .], te creen partidario del Gobierno, y como ellos, por tener sus puestos seguros están casi todos en la minoría, son capaces de cualquier atrocidad por darle un disgusto a tu tío. ( $L a$ conjura 154$)^{4}$

De esta manera, Joaquín también trata de llevar a Augusto por el camino apicarado en su vida profesional: "El gran golpe tuyo hubiera sido obtener una recomendación del mismo Villarín para el Tribunal; esto hubiera significado una invitación a la paz; se aprobaba el crédito; te calzabas tú la cátedra y ipaz Chisti! ... " (La conjura 155). 
Como predijo Morell, las oposiciones fueron un fracaso para Augusto, no por su incapacidad, sino por las intenciones ocultas y los intereses personales en juego. Con este nuevo golpe se afianza más en la mente de Augusto la idea de que existe una conjura en la sociedad que impide el progreso del individuo por las vías legítimas, lo que hace que cada vez esté más cercano el momento en que él también busque el acomodo por medios menos respetables. En un último intento por llegar a afirmarse con honestidad; aunque utilizando la influencia de su amigo, trata de conseguir una plaza de médico en una clínica, gestión que termina en una nueva decepción. Sus conocimientos de filosofía, ampliamente demostrados en un libro que había publicado recientemente, son la excusa para negarle la plaza. Solamente le queda la esperanza de que su amigo obtenga un importante puesto en el gobierno para poder conseguir lo que se propone. De esta manera, casi sin darse cuenta, Augusto Román se va acercando cada vez más al tipo del pícaro. También en cuanto al matrimonio influye Morell en las ideas de Augusto. Numerosas veces le recomienda que termine su relación con Antonia porque lo perjudica socialmente y le hace ver la conveniencia de un matrimonio con Luz O'Brien "iCómo que es cosa de despreciar este partido!... Tú, sin duda, no sabes lo que pesa este inglés en la Banca: un millón en efectivo; interesado en las grandes empresas; [. . . ]. Cierto que 
en todas las esquinas no se encuentran Venus... Pero créelo: el dinero lo adorna todo..." (La conjura 176).

Augusto se da cuenta de que todas las puertas se le cierran, y que la causa principal es su relación con Antonia. Sorprendentemente, el rechazo final de esta relación causa la inmersión de Augusto en la visión picaresca de la realidad, al descubrir que él era uno más dentro del esquema romántico de la mujer. La nueva situación propicia la reflexión y el análisis. Acepta que " [. . .] el mecanismo de convenciones establecidas era más fuerte de lo que él pudiera sospechar [. . .]" (La conjura 186); reconoce "[. . .] que más que el talento puede la astucia..." (La conjura 187); y justifica el comportamiento de algunos de los que lo habían traicionado:

La una, hembra sensual, inconsciente, hecha exclusivamente para el amor de ocasión, imposible de ser regido por una vida en pareja... El otro, alegre, vividor, que veía el mundo como una cosa muy simple, creada para diversión de los hombres... La vieja, antigua prostituta que bastante había hecho con servirle de ama de llaves a cambio de pan y techo; se le presentó una buena ocasión de buen negocio, y la había tomado al paso. (La conjura 188)

En este momento, Augusto se da cuenta de que con su forma de ser, nunca lograría sus objetivos, y se pregunta: "¿Es que no se puede ser 
bueno, confiado, generoso en el mundo?... ¿Es que hay que ser cruel y malvado; es que hay que pisotear al prójimo para no ser pisoteado por él?" (La conjura 189). Llega a la conclusión de que "s[. . .] si se calificaba de listo al que con más éxito procurase en el mundo su bien, era concluido que en su drama, sostenido por una turba de listos, el que hacía el papel de tonto no podía ser otro que él" (La conjura 190). Al final, su tío tendría razón, porque él solamente "[. . .] le dictaba reglas para llevarlo a lo que él creía el ideal de todo joven animoso: la riqueza, el prestigio social, el matrimonio conveniente; lo que había sido antes su programa de vida, dichosamente cumplido" (La conjura 189).

De esta manera, asistimos al momento final de la conversión de Augusto en pícaro. A partir de este instante, acepta que "[. . . ] todo era cuestión de acomodación [. . .]" (La conjura 192), y empieza a pensar en Luz O'Brien como una posibilidad para iniciar el nuevo tránsito:

No era un disparate soñar que algún día pudiese casarse con ella. Todos lo predecían; ella misma justificaba las presunciones con sus sonrisas y sus rubores; nadie se oponía a ello... [. . .] casi podía aventurar que en ella estaba la fórmula de transacción entre sus ideales y sus necesidades físicas... ¿Qué mejor elemento que el dinero abundante gastado, para cultivar una ciencia inútil, improductiva en el sentido inmediato y económico? (La conjura 192-193) 
Augusto había encontrado la fórmula del éxito en el matrimonio por conveniencia con Luz O'Brien: "Hacerse rico, para hacerse después sabio" (La conjura 193), o sea, asumir la actitud picaresca. Si antes había pensado en huir de la ciudad para evadir la situación en que se encontraba, después de todas esas reflexiones se produce una completa transformación:

El antiguo Augusto Román, macilento y alucinado, había muerto; poco importaba que en vez de huir de la ciudad se hubiese desvanecido aquella misma noche. En su lugar abría los brazos potentes un nuevo Augusto Román, ávido de placeres sensuales y poco preocupado de averiguar el desenvolvimiento de la manera. (La conjura 194)

Al final de la obra, Augusto Román se ha convertido en un ser a quien la frustración y el desengaño lanzan por el camino más fácil, el del pícaro. No hay que luchar contra el orden imperante, sino sacar provecho del mismo.

Otro personaje que al comienzo de la novela se destaca como un ser diferente en aquella sociedad corrupta y apicarada es Margarita Villarín, hija de don Próspero y prima de Augusto. La primera noticia que tenemos de la existencia de este personaje es una carta que le escribe a su primo. El narrador señala las características físicas de la correspondencia: "un sobrecito coquetón, menudo, de un tono verde 
aguado. La letra, delgada y nerviosa [. . . ]" (La conjura 139), quizás en un temprano intento de darnos a conocer a la persona que escribe la misiva. Ese sobre nos hace adivinar la personalidad del remitente, alguien frágil, débil, suave, de temperamento nervioso, que se complementa con la evocación que de la prima hace Augusto: " [. . .] una figurilla delgada, pálida, de dulce mirar soñador, sombreado el rostro oval y puro por una undosa mata de cabellos negros; una de esas frágiles siluetas que se han visto antes en los cuadernos sin acabar de los artistas" (La conjura 140). Entre estos dos personajes existe una afinidad. Cada uno es cómplice y confidente del otro. Ella, a pesar de parecer estar resentida por la ausencia del primo (lo llama "falso"), le advierte de las opiniones que otros miembros de su círculo de amistades tienen de él: "Sé de ti algunas veces por los amigos, que me dicen que estás intratable" ( $L a$ conjura 139), sin embargo, ella no acepta esa imagen del primo, y afirma: "¡Yo no lo creo [. . .]!" (La conjura 139). Es ella una de los pocos personajes que entienden y justifican el comportamiento de Augusto Román. Le ve con otros ojos y comparte con su primo, hasta cierto punto, si no la rebeldía hacia las convenciones sociales, sí una especie de rechazo. Esto puede deducirse cuando le confiesa en su carta que: "[. . .] en estos días, como he ido a tres bailes, estoy abrumada de tonterías y necesito desahogarme con alguien que merezca mis desahogos" ( $L a$ conjura 139). Esta cita nos demuestra que, aunque ella participa de las 
actividades sociales propias de la clase a que pertenece, las mismas no son totalmente de su agrado. ${ }^{5}$

La situación de Margarita dentro de su entorno social se diferencia de la de Augusto en que ella es hija de un funcionario del gobierno. Esto la coloca en una posición más ventajosa, porque no necesita "arrimarse a los buenos"; sin embargo, su condición de mujer, hace que también sea vulnerable a las trabas y a los convencionalismos imperantes en la sociedad en que se desenvuelve. Su carácter, idealista, soñador, puro, contribuye a aumentar aún más esa vulnerabilidad. El propio Augusto se preocupa por el destino de su prima, y se pregunta: "¿Qué suerte esperaba en el mundo a aquella muchacha romántica, tan poco comprendida en su medio, y cuyo tesoro de sensibilidad y sutileza resumían sus padres Ilamándola la mística?" (La conjura 140-141). Otro peligro al que está expuesta Margarita es a los pícaros burgueses, a quienes Augusto se refiere como "[. . .] esos salvajes de frac [. . .]" (La conjura 140), que puedan utilizarla como medio para lograr sus objetivos. Debido a que el comportamiento de Margarita en sociedad no estaba de acuerdo con las convenciones de su clase, no tenía muchas probabilidades de lograr una relación amorosa sincera. Si algún día quería casarse, tendría quizás que aceptar un matrimonio por conveniencia, o como diría su primo, tendría "[. . .] que adornarse el cuerpo con un cheque lleno de cifras [. . .]" (La conjura 145), para que 
algún hombre le diera algún valor. Y así finalmente sucede, ya que termina aceptando como novio a Joaquín Morell solamente días después de que éste recibiera el nombramiento de subsecretario de Hacienda. Finalmente, ella también cede a las convenciones sociales al aceptar a un hombre que sólo busca su dinero y posición social; pero quizás no sea tan víctima y haya actuado también por interés, como se deduce de las palabras de su amiga Luz O'Brien: "Un lindo subtítulo en las tarjetas convence a las mujeres más inteligentes" (La conjura 172). De esta manera, un personaje que aparecía como idealista y puro, termina también buscando el acomodo, actuando de manera fría y poco auténtica, poniendo a un lado sus ideales, accediendo a una visión picaresca del mundo. Al final de la narración, el propio Augusto, con cierto tono de desengaño, lo confirma, cuando hace un recuento de los personajes que cree comparten sus ideas, y nota el cambio que ha dado su prima: "Ahí está Margarita [. . .]; Margarita, en quien soñé ver una secreta identificación, y que, como todos, se dejó ir en la corriente..." (La conjura 190-191). Como Augusto, Margarita también cae en un comportamiento acomodaticio, empujada por los formulismos de la sociedad donde se desenvuelve.

Entre los personajes de La conjura, uno que exhibe desde el principio rasgos de carácter picaresco es Joaquín Morell. Es éste un personaje que pertenece a una clase social relativamente alta. Es abogado 
y se mueve dentro de las esferas de una aristocracia provinciana; sin embargo, se perfilan en él rasgos del pícaro tradicional, pero adaptados a la sociedad en que se desenvuelve. Por Augusto sabemos que Joaquín es " [. . .] alegre, buen bebedor, fuerte como un toro, sin muchas ideas que le arrugaran la frente [. . .]; no sufría del mal de las preocupaciones; para él no había problemas; con darle gusto a la sociedad y romper con lo que le estorbara" (La conjura 136). De esta imagen se desprenden por lo menos tres características del pícaro (si bien con modificaciones): el vicio (la bebida), su capacidad proteica y su falta de escrúpulos para lograr lo que quiere.

Para Joaquín es sumamente importante representar su papel todo el tiempo, porque de esta manera logra engañar a la sociedad. En una escena, lo encontramos vistiendo totalmente de negro. Cuando Augusto le pregunta que si tiene luto, le dice que no, que es "por la ceremonia", y enseguida agrega: "Tengo una visita... ¿Qué, te figuras que a eso se puede ir así como así?... No, no te rías... Tú no puedes dejar de comprender que nuestro ministerio... que la sociedad..." (La conjura 142). Esta aceptación del status quo, como algo inalterable, es otro rasgo de la personalidad del pícaro tradicional ${ }^{6}$. Por otra parte, este personaje se mueve en los niveles propicios para el desarrollo de su condición de pícaro. El propio Augusto reconoce en la filosofía de Joaquín la forma para conseguir llegar a algo en la vida cuando afirma "[. . .] tu llegarás 
lejos" (La Conjura 142). Pronto ocuparía Joaquín Morell la subsecretaría de Hacienda en el gabinete del gobierno.

Es interesante señalar que el personaje de Joaquín puede parecer alejado del pícaro tradicional por el lugar que ocupa en la sociedad cubana republicana. Joaquín es profesional, igual que Augusto, y no un huérfano, pobre y hambriento; tiene un hogar y una familia que lo admira. Sin embargo, es su idiosincrasia, su forma de actuar para burlar y manipular los recursos que tiene a su alcance con el fin de subir más en la escala social, lo que lo acerca a sus antepasados del Barroco.?

Joaquín Morell, siguiendo su filosofía picaresca, no solamente nos recuerda al personaje del pica-pleitos, uno de los tipos retratados en Los cubanos pintados por si mismos ${ }^{8}$, sino que también, hasta cierto punto, encarna al vividor, otro personaje típico de la sociedad cubana. A pesar de ser abogado, Joaquín no está conforme con su situación, quiere mejorar, subir en la escala social, y una manera de lograrlo es conseguir un buen partido para casarse. Mediante una conversación que tiene el abogado con Augusto sobre las relaciones amorosas de este último, se hace aún más patente su actitud picaresca ante todos los aspectos importantes de la vida. Al confesarle Augusto sus motivos para no dejar a Antonia, le responde: "[. . .] si todas las razones que yo tuviera para un caso análogo fueran ésas, ya la hubiera despachado con cajas destempladas..." (La conjura 143). No existe en él ni compasión ni amor, 
y lo reafirma al decir: "Pues a mí no me cortan el paso estos conflictos... Aquí me tienes soltero y libre hasta que encuentre una buena proporción... No me vendo por menos de cien mil duros" (La conjura 144). Joaquín, como el vividor, anda en busca de una rica heredera y su presa no será otra que Margarita Villarín, quien a pesar de considerarla un poco masculina por su gusto por la literatura, se convertirá en su compromiso.

Este personaje usa también las armas de la trampa, la burla y el subterfugio para lograr sus propósitos y disfrutar de los placeres de manera patente en su relación con Antonia. Le aconseja a Augusto que rompa con la amante, a la que considera vulgar y de poco valor, como no sea para una aventura. Sin embargo, no duda en tener una relación con ella, traicionando así no solamente al que lo cree su amigo, sino también a la mujer con quien está comprometido.

En Antonia, la amante de Augusto, se perfilan rasgos de la psicología del pícaro. La primera noticia que tenemos de este personaje es la alusión que a ella hace don Próspero cuando le critica a su sobrino que mantenga una querida. Esa querida es Antonia, una enfermera que Augusto conoció en el hospital donde ambos trabajaban. La descripción inicial del personaje nos sugiere ya un parentesco con las pícaras tradicionales: "Era [. . .] una muchacha delgada y fuerte, muy alegre y muy limpia, siempre propensa a dormirse en las guardias nocturnas" ( $L a$ 
conjura 137). De este juicio se desprende una imagen de mujer, que como las pícaras de los siglos XVI y XVII, tiene buena apariencia.

A través de la mayor parte de la obra Antonia aparece caracterizada como un ser extremadamente sensual. Así la pinta Augusto:

[ . . .] vulgar, alegre, sensual [. . .] llenando el sillón con las espumas nítidas de la bata; en alto los brazos desnudos, cruzados sobre el respaldo. Era una de esas rubias opulentas que brindan a los besos un brillo dorado sobre la carne láctea. Alta y bien hecha, habría poseído una elegante silueta si los hartazgos por igual del sueño y la mesa no la hubieran deformado. De la terrible invasión del tejido adiposo se habían salvado, no obstante para la gracia, su cara y sus manos: éstas, pequeñas, rosáceas y sembradas de hoyitos; aquélla, formada por menudas facciones de niña, donde charlaban dos ojos verdes llenos de puntos de oro. ( $L a$ conjura 136)

Por su parte, Joaquín Morel, la considera " [. . . ] demasiado vulgar para vivir mucho tiempo en el espíritu de un hombre inquieto y sentimental, como no fuera en las rápidas caídas de las sensuales epopeyas [ . . .]" (La conjura 143); o sea, como un mero objeto sexual.

Aunque al principio Antonia se gana la vida con su trabajo, hay en ella algo que provoca a los hombres que la rodean: "Pero aún cuando no 
pareciera interesante, algo había en su rostro y en su continente que decían claro que aquella mujer había venido al mundo para que le faltasen al respeto. De si la tácita invitación era aceptada, podían hablar los médicos y practicantes de su sala [. . .]" (La conjura 137). Este papel activo de la mujer en la iniciación de una relación amorosa, característico de las pícaras barrocas, se hace aún más patente en la relación AugustoAntonia:

Aquel blanco gorrito que se paseaba gallardo, desafiante, por patios y corredores retozó una mañana de mayo en el corazón de Séneca, [ . . . y [ [ . . ] se abrió para el buen niño grande una era de aventuras impensadas [. . .] Uno de los dos rendía la flor de su pureza; y por esta vez no fue Julieta la víctima de Romeo... (La conjura 137)

De esta manera, Antonia utiliza sus dotes físicas para medrar. ${ }^{9}$

Además de la atracción erótica, Antonia pone en juego otros elementos para poder subir en la escala social. Uno de estos elementos es la astucia. Producto de su relación con Augusto o, quizás con otro, hay un embarazo, y Antonia aprovecha esta situación para manipular a Augusto y hacer que éste le ponga casa propia. Una vez logrado su propósito, su pragmatismo la lleva al aborto, convirtiéndose en querida de Augusto que de ahora en adelante la mantendrá. ${ }^{10}$ Convertida en amante, Antonia pasa a ser la "señora de la casa", y en esta transición 
surge la pícara que no tiene amos, sino que es servida por los demás:

"Hoy ha habido que llevarle el almuerzo a la cama [. . .]" (La conjura 134). Su madre se refiere a ella como "la princesa" y le comenta a Augusto que Antonia dice "[. . .] que a ella no la manda nadie..." (La conjura 134).

Al final de la narración, el carácter picaresco de Antonia se completa al traicionar a Augusto. Después de saber que el hombre lo ha sacrificado todo por ella, no vacila en engañarlo con el abogado Morell. Este hecho demuestra que Antonia, como muchas de las pícaras del Barroco, es cruel, infiel, ingrata y traidora. Su crueldad se hace patente cuando le grita: "¡Pues bien, sí; [ . . ] con ése y con otros más, para que lo sepas! [. . .] Porque no eres un hombre más que a medias... ¡Verraco!..." (La conjura 185).

Por su parte, doña Concha, la madre de Antonia, es un personaje no solamente picaresco sino, en algunos momentos, celestinesco, y, a nuestro juicio, toda celestina tiene una filosofía de vida que se inscribe en la picaresca." A pesar de que doña Concha, a veces, señala abiertamente las características picarescas de su hija, vemos que ella también busca la vida acomodada a expensas de Augusto. El narrador ilustra la filosofía picaresca de doña Concha en la actitud que toma ésta ante el embarazo de su hija. Al darle la noticia del suceso a Augusto, "la vieja reía convulsivamente, guiñando un ojo con aire de confidencia, gozosa ante el porvenir asegurado, tal vez con el fantasma del tío 
ministro bailando detrás de sus retinas" (La conjura 137). Así, la llegada del nieto para doña Concha no es motivo de alegría por razones de amor, sino porque el niño será el medio para "medrar", objetivo final de todo pícaro, según José A. Maravall.

En Miguel, el hermano de Antonia, a pesar de ser uno de los personajes menos importantes de la narración, también se evidencia su condición de pícaro. Miguel tiene como cómplice de su actitud picaresca a su propia madre, quien lo mima, justifica su conducta y lo ayuda a sacar provecho de Augusto: "Oye, [. . .] no te olvides de los tabacos para Miguel... Viene esta noche... El pobre está muy mal ahora..." (La conjura 134). La imagen picaresca está explícitamente dada en la presentación que del personaje hace el narrador: "Miguel era el hijo mayor de doña Concha, un vividor de buen aspecto y mala fama, que era la debilidad de la vieja, y a quien las gestiones angustiosas de Augusto Román habían sacado a duras penas de varios líos policíacos" (La conjura 134). ${ }^{12}$

Entre los personajes que por su posición social y económica no se relacionan con el pícaro tradicional, cabe destacar a don Próspero Villarín. Este personaje, tío materno de Augusto Román, representa en la novela el status quo. Ocupa un gabinete en el gobierno de la recién estrenada república y puede, mediante sus numerosas influencias, conseguir un puesto importante para su sobrino; sin embargo, cada una de estas oportunidades va acompañada por unas condiciones que Augusto tendría 
que cumplir. Se plantea así un juego entre el que tiene el poder y el subordinado. Augusto solamente podrá contar con la ayuda de su tío si se deja manipular por la sociedad.

Don Próspero no exhibe un comportamiento picaresco, pero incita a su sobrino a que viva de acuerdo con la filosofía del pícaro. Predica el pragmatismo, aunque éste conlleve la renuncia a los más caros valores del ser humano: "[ . . ] acabó por atiborrarle de vacíos consejos sobre lo práctico y lo no práctico de la vida y sobre la imposibilidad de llegar a ser algo en sociedad por medio de los libros y el microscopio" (La conjura 131).

Disfrazado de ministro, Villarín predica la filosofía del pícaro: no solamente hay que adaptarse, hay que ser proteico para llegar a ser alguien; hay que saber jugar el juego del poder. La filosofía de vida del pícaro va implícita en las alabanzas que hace don Próspero de un puesto que acaba de ofrecer a su sobrino: "Es un puesto que te conviene mucho; te hace entrar en trato con senadores, representantes, extranjeros... ¡Oh, y de mucho prestigio!...Si te cogen unas elecciones verás lo que vale tener doscientos hombres bajo tu mando..." (La conjura 151). Esta actitud picaresca dentro de la arena política y de los ministerios públicos era bastante común en la sociedad, según se infiere del siguiente comentario: "[. . .] no era don Próspero, sino la ciudad entera, la trabazón 
social, quien hablaba" (La conjura 141). La idiosincrasia picaresca de Villarín era una representación simbólica de la vida nacional.

Un personaje que contrasta con todos los anteriores es el viejo profesor Velazco, maestro de filosofía de Augusto. Lo conocemos cuando Augusto realiza una primera visita a su hogar. Desde antes de entrar a la casa donde el personaje habita, se hace evidente la miseria que lo rodea. La descripción de la fachada de la casa, anticipa las circunstancias en las que se desenvuelven el profesor Velazco y su familia. El deterioro que conforma la realidad humana y física del lugar da fe de lo que se intuye al llamar a la puerta: "el reloj, detenido hacía años bajo su fanal; el sofá, de retorcidos brazos; que fuera macizo si de él no diera buena cuenta el comején; la lámpara de lira, el espejo de medallón picado de viruelas; el cuadro sombrío del fondo, donde un terrible naufragio se desarrollaba [. . .]" (La conjura 156).

El profesor Velazco es el único personaje de La conjura que resiste las presiones de la sociedad. No claudicó, ni se dejó manipular, aunque sabía bien que esta postura le llevaría a nada dentro de ese orden social. Con el personaje de Pascual Velazco, Castellanos completa la visión que tenía de la sociedad cubana de la época, y pone en boca del personaje palabras que encarnan la filosofía del desengaño. Cuando Augusto visita al profesor, éste le dice: "Eres un buen muchacho [. . .]. Lo siento por ti, porque no harás carrera nunca... Te pesa mucho la vergüenza para que 
puedas caminar aprisa..." (La conjura 156-157). Así mismo, cuando Augusto le comenta que se va a presentar a unas oposiciones para lograr una cátedra de un instituto, le señala:

¿Es decir que todo a lo que aspiras es a ser un miserable Pascual Velazco, vestido de verde, peleado con el Director porque no quiere asistir a las recepciones oficiales en clase de candelabro, relegado a la peor aula del edificio, perseguido por el obispado por sus doctrinas en clase, [. . .] desconocido por los políticos que van saludando a todo el mundo a derecha e izquierda... (La conjura 157)

Esta actitud vertical, de no aceptar el juego del poder, lo llevó a las condiciones en que ahora se encuentra. Su rechazo a adoptar la actitud picaresca que podría haberle proporcionado el éxito social, le trajo como consecuencia llegar a la vejez en la miseria y el olvido. Velazco sabe, y se lo advierte a Augusto, que el proceso de transformación en pícaro, aunque necesario, es difícil, porque hay que poseer una capacidad proteica para adaptarse y modificar el comportamiento y desterrar toda preocupación ética.

El personaje del viejo profesor también se diferencia de los demás porque es el que sostiene una actitud más crítica de la sociedad. Su conversación con Augusto demuestra que si alguno está consciente de la realidad social de la época es él. Hace hincapié en el hecho de que en 
aquella sociedad es prácticamente imposible llevar a cabo ninguna actividad espiritual y elevada. En su opinión sólo es posible, trabajar, comer, dormir y tener relaciones sexuales. Todo lo demás está fuera de las posibilidades del ciudadano común, si uno no cumple con lo que él llama "pequeños deberes cortesanos" (La conjura 158). Estos pequeños deberes cortesanos conllevan un comportamiento hipócrita y a la vez proteico que se manifiesta en función de los diferentes objetivos de cada individuo.

En conclusión, se puede afirmar que en la mayoría de los personajes de La conjura se observa un comportamiento de tipo picaresco, independientemente del lugar que ocupa cada uno en la escala social. Algunos de ellos, como don Próspero Villarín, predican la filosofía picaresca; otros como el profesor Velazco, simplemente aceptan que, para triunfar en esa sociedad, hay que caer en el juego establecido por el orden social, o sea, hay que apicararse, aun a expensas de los más caros ideales.

\section{La manigua sentimental.}

La manigua sentimental es, según Max Henríquez Ureña, "una de las más bellas evocaciones narrativas [. . . q que se conoce de la guerra de independencia cubana [. . .]" (2:341). Sin embargo, como muy bien señala Luis Toledo Sande, Castellanos "no escogió las grandes 
heroicidades de la gesta" ("Prólogo" La conjura 25). A pesar de que se hace mención de grandes héroes como Antonio Maceo y Máximo Gómez, y de que se alude a momentos importantes de la guerra, como la Invasión de Oriente a Occidente, esto solamente es el telón de fondo que utiliza para situar a un personaje que relata las aventuras vividas en la manigua y fuera de ella, a la vez que enjuicia los hechos históricos desde su propia óptica. Es interesante recalcar que en un momento del relato, el protagonista afirma que "[. . .] la impedimenta es el eslabón más curioso de la guerra" (La conjura 296). Es decir, que en la narración, la experiencia vital humana juega un papel más importante que el hecho histórico en sí. Es en "la impedimenta" donde se encuentra la semilla de la narración. Después de haber comentado algunos de los hechos de la guerra, expresa claramente que esa no era su intención, al decir: "Os he hablado más de lo que quería del curso homérico de la insurrección" ( $L a$ conjura 308). Esta cita lleva al lector a inferir que la guerra de independencia, en esta obra, es solamente un hecho tangencial, en cuanto a que da pie a una serie de vivencias del protagonista; pero la misma no ocupa el centro de la narración. Al situar Castellanos a un personaje como Juan Agüero en un contexto heroico, logra que la naturaleza antiheroica del mismo se haga mucho más evidente.

La novela se inicia con una pregunta: "¿Por qué estaba yo en la guerra?" (La conjura 289). Esa pregunta justifica la narración ${ }^{13}$ y a la 
misma vez lleva al lector a sospechar que ese "yo" tiene unas razones para ir a la guerra de independencia que no son el patriotismo, el idealismo y las ansias de libertad. La pregunta nos pone sobre aviso en cuanto al carácter del protagonista que desde el inicio se perfila con una postura picaresca.

Es curioso el hecho, y vale la pena señalarlo, que a pesar de ser ésta una obra enmarcada en un momento histórico fundamental del país, la estructura de la obra, desde los propios inicios, lleva al lector a relacionarla con la picaresca tradicional, no solamente por estar narrada en primera persona, sino por ser el recuento de las aventuras de un individuo sin importancia histórica. Es casi imposible no pensar en Lazarillo de Tormes cuando leemos el primer párrafo de la narración: Antes de pasar adelante y para que tengáis una idea de mi persona, os diré mis apellidos: Agüero y Estrada. En cuanto a mi nombre no hay que ir tan lejos: me llamo simplemente Juan. Mis padrinos, desdeñosos acaso ante mi lámina esmirriada y lamentosa, no me creyeron digno de ser Bernabé o Serapio, como los héroes de aquel entonces de hace treinta años. (La conjura 289)

Vemos así que Juan, como Lázaro, inicia el relato de sus aventuras con una presentación que alude a su linaje, y lo hace con la intención de justificar, hasta cierto punto, sus acciones posteriores. De la cita se 
desprende que, aunque de ilustre ascendencia, desde el momento mismo de su nacimiento Juan no era un héroe, hecho que se corrobora numerosas veces en el desarrollo de la narración, y respalda su filiación picaresca.

El protagonista no tarda en descubrir las verdaderas razones que lo hacen unirse al ejército libertador. Se va a la manigua para no deshonrar su linaje:

En mis abuelos fue una costumbre guerrear contra la España colonial. [. . .] Mi padre, [. . .] fue aquel Agüero y Castillo que con su bello gesto de libertar en la mañana de la sublevación en su batey, a sus trescientos negros de dotación, asombró a los oficiales [.. .] de Palacio, y hasta inspiró una oda. [. . . ] y a ambos lados de la línea recta se esfumaban tíos emigrados, primos con el grillete al pie, buenas señoras que portaban toda una documentación revolucionaria en las varillas del malakoff... Pensad en esta mole de tradiciones sobre un mísero estudiante de Derecho, boquirrubio y almidonado. [.. .] No esperé a que me lo recordaran las muchachas de mi calle, ya bien insinuantes con sus lazos azules y rojos. Corrí a la guerra. (La conjura 289-290)

Esta acción de Juan ejemplifica su conducta proteica, ya que sin tener madera de héroe, se incorpora a la gesta libertadora. Por otra parte, este 
acto no es más que una parodia del honor, porque aunque el hecho de irse a la manigua honra a su familia, los verdaderos motivos que tiene para hacerlo son una deshonra. Más tarde, sus acciones durante su participación en la guerra y después de ella, ponen en tela de juicio la razón de honor.

La filosofía de vida del personaje se va esbozando a medida que avanza la narración, y poco a poco va surgiendo una figura de perfil picaresco. En un momento en que el líder del batallón al que pertenece Juan decide atacar un pequeño poblado, éste, con su sentido pragmático, característico del pícaro, comenta: "Mis juicios de pacífico metódico se desconcertaban al pensar qué iba a ganar nuestro coronel con la conquista de aquella plaza miserable en que por seguro, no habría ni con qué remojar la garganta" (La conjura 291). Más adelante confiesa una actitud acomodaticia frente a la vida, reñida con la forma de vivir de un verdadero mambí:

Soy simplemente [. . .] un cómodo. Dilettante de los chocolates en la cama, espectador de los estrenos, ducho en las juergas de moda, ¿cómo podían conciliarse estos urbanos gustos míos con aquella vida a salto de mata, limpio el estómago y andrajosa la indumentaria? (La conjura 292)

Otro hecho que ilustra la actitud proteica de Juan, así como su falta de principios es su relación con Juanilla y Esperanza Fundora. Se enreda 
en una relación amorosa con la primera, mujer sensible y frágil, y no tiene otro remedio que casarse con ella cuando todo se descubre; sin embargo, no deja de codiciar a la hermana de su mujer, que es mucho más sensual y atractiva. Esta atracción lo llevará a escaparse con ella en cuanto tiene una oportunidad, abandonando a su esposa embarazada.

Juan es un personaje que no pierde la ocasión de utilizar cualquier camino, si es honorable, mejor, para resolver sus asuntos personales y justificar lo que de otro modo podría parecer una conducta poco decorosa. Cuando se le presenta la oportunidad de unirse a la Invasión que iría de Oriente a Occidente, ve en ella la forma de abandonar a su mujer justificadamente, con el pretexto de servir a la patria, y así lo confiesa:

Aquel matrimonio y el paso de las huestes de la Invasión, fueron en mí dos ideas asociadas, una de las cuales podía resolver la otra. [. . .] Comprenderéis ahora que mi cabeza se Ilenase en aquellos días de planes estratégicos, no muy militares tal vez. Y pensé mucho en la incorporación a las huestes invasoras, quizás sin llegar a Occidente. Fórmula decorosa, caballeresca si queréis. Ella permanecería en Camagüey, con los míos. (La conjura 306)

Su decisión de participar en un acto heroico, conlleva la evasión de una responsabilidad. Sin embargo, cuando su mujer y la familia de ésta 
comunican que se incorporan al proceso libertario, arruinándole de esta manera su plan, es muy tarde para echarse atrás y dice: "Y casi, a la fuerza, fui invasor" (La conjura 306).

La participación forzada de Juan Agüero, de acuerdo con sus planes, en la Invasión, no fue prolongada. El hecho de llevar consigo a la familia sirvió de excusa adecuada, puesto que los altos mandos impedían el acompañamiento de los soldados por sus familiares. De esta manera, Juan abandona las huestes invasoras honorablemente, y se instala en las posesiones que su familia tenía en Camagüey.

Durante la estancia de Juan y su familia en la finca La Caoba ocurre un hecho en el que Juan demuestra, una vez más, su falta de escrúpulos y su carácter picaresco. Una noche fueron atacados por la guerrilla y, en la confusión del ataque, Juan logra escaparse, abandonando a su mujer. En su escapada se encuentra con Esperanza Fundora, y, olvidando que tenía una mujer y un hijo en camino, le propone que sea su pareja.

A partir de este episodio, Juan hace uso de la trampa, la burla y el subterfugio para lograr sus objetivos. Primero, junto con Esperanza: al ser interrogados, se hacen pasar por una pareja de campesinos cuyo bohío había sido incendiado, quedando sin sitio. Después, logran llegar a la ciudad de Camagüey y como es necesario conseguir dinero a toda costa, le escribe a su padre una carta "[. . .] discreta, y en ella se aludía muy veladamente a cierta misión [. . .]" (La conjura 317) que requería que 
viajara desde La Habana hacia Nueva York. Mediante el engaño, una vez más adopta el papel de héroe para medrar en sus propósitos.

A partir de este momento, se inicia otra etapa de la vida del personaje en la que recurren los rasgos picarescos. Para poder mantener el engaño vive escondido, llevando una existencia parasitaria a costa de su padre. Posteriormente, la falta de dinero lo fuerza a engañar también a Esperanza y la hace concebir falsas ilusiones con respecto a su relación amorosa: "Entonces fantaseé. Hablé de un empleo que me reservaba un antiguo amigo de mi padre; de buscar a los viejos compañeros, de acabar los estudios... Hasta dejé vislumbrar allá, a lo lejos, remotos, los muros encalados de la Vicaría..." (La conjura 319).

Juan, como Lázaro, permite que su amante use su cuerpo para obtener favores de un hombre cuando se ven en una situación difícil y comenta que Esperanza "[. . .] consintió al fin, encargándose de ablandar al posadero" (La conjura 319). Finalmente, abandonan el hospedaje por falta de dinero y se instalan en la casa de un amigo de Juan. Esta nueva situación propicia la infidelidad de Esperanza que, finalmente, lo abandona. Juan no la busca, sino que se resigna. Esta actitud de Juan ante el abandono de Esperanza lo acerca al pícaro, que se caracteriza por aceptar las reglas del juego amoroso, pero sin involucrarse de forma definitiva en la relación. 
Así terminan las aventuras de Juan Agüero. Al final de la obra, como Lázaro, lo encontramos, hombre casado, convertido en un "llano y burgués inspector de escuelas" (La conjura 324), posición que logró como recompensa por sus servicios a la patria. De esta manera, como todo buen pícaro, Juan logró establecerse con éxito en la sociedad, aprovechando todas las oportunidades que la guerra le brindó.

Por su parte, Esperanza Fundadora también presenta rasgos que llevan a lector a relacionarla con la tipología picaresca. Esta joven campesina, desde el primer momento despierta los deseos de los hombres del grupo, incluyendo al mismo Juan. Si no tiene nada con ella al principio, es porque su amigo Luján le confiesa que hay algo entre él y Esperanza. En la novela hay numerosas referencias al cuerpo de Esperanza: caderas, senos, su forma de caminar y de sonreír que proyectan una conciencia del dominio que el cuerpo puede ejercer. Después de la relación con Luján y durante la estancia en la hacienda La Caoba, se sabe que anda de "buscona" y se escapa con numerosos hombres, regresando a la hacienda cuando le conviene. Esperanza, como buena pícara busca hombres que tengan una mejor posición dentro de las circunstancias en que ella se mueve. Un día "[. . .] se fue con un comisionado [...] Después volvió como si tal cosa..." (La conjura 309). 
Como la mayoría de las pícaras, Esperanza desempeña un papel activo en el inicio de las relaciones eróticas. Dice Juan: "[ . . ] cuando junto a mí cruzaba, [. . .] sus pupilas tenían más cambiantes de luz, su cintura se anchaba más al andar, sus manos se hacían más temblorosas al resbalar por su pelo bronceado y tomaban, en suma, una aguda exaltación sus potentes órganos de sembradora" (La conjura 309). Es traidora, ingrata y mentirosa. Con su actitud provocadora atrae a su cuñado, y sostiene relaciones con él a escondidas. Cuando se da la ocasión de huir con él no vacila en hacerlo, sin tener en cuenta que la esposa abandonada es su propia hermana. Mientras comparte la vida con Juan es cómplice de sus mentiras; pero una vez agotado el dinero que habían conseguido del padre de Juan, deja ver que lo único que la unía a este hombre era el interés. Se da cuenta de que su afán de medro no llegará a ningún destino con Juan y demuestra su decepción: "Es decir, que todo lo que tú traías, todo lo que el viejo te había dado... ¿era esa miseria?" (La conjura 319).

A partir de este momento, Esperanza no vacila en ejercer el poder de su cuerpo y seduce, con el consentimiento de Juan, al dueño del lugar donde se hospedaban para lograr quedarse allí sin pagar. Luego, empieza a tener relaciones con diferentes hombres, hasta que un día culmina la aventura cuando traiciona a Juan y lo abandona. Sabemos al final, que ella ha logrado "arrimarse a los buenos", pues la última noticia que de 
ella da el narrador es que la vio en un parque junto con otras mujeres, y había notado el "progreso evidente de sus ropas y su sombrero" ( $L a$ conjura 231). Así, Esperanza se sirvió de las condiciones de guerra existentes para lograr situarse en una posición mejor de la que se encontraba al principio de la narración.

Al finalizar el estudio de esta obra, se observa que a pesar de que la narración está situada históricamente en el marco de la gesta libertadora cubana, el comportamiento picaresco del protagonista y de otros personajes principales, como Esperanza Fundora, le sirven al autor para criticar la actitud oportunista y acomodaticia de algunos de los que participaron en el proceso emancipador.

\section{Conclusión.}

Después de realizar un estudio minucioso de las novelas $L a$ conjura y La manigua sentimental desde una perspectiva de la picaresca, se ha observado que muchos de los personajes principales de la narrativa de Castellanos presentan una psicología y filosofía de vida que, salvando las diferencias de tiempo y espacio, los acerca de manera definitiva a los pícaros de los siglos XVI y XVII. A pesar de que muchos de estos personajes no son de baja extracción social, como Lázaro, ellos también, de una forma u otra, tienen el deseo de ascender en la escala social. También como Lázaro, en la mayoría de los casos, no desean cambiar las 
condiciones en que se encuentra la sociedad, sino aprovecharse de las mismas para lograr lo que quieren. No hay, en la mayoría de estos personajes, un espíritu de lucha y de rebeldía, sino una actitud acomodaticia y una falta de escrúpulos que los llevan a usar los valores más nobles, como el patriotismo, para escudar sus intenciones más mezquinas. Por otra parte, se observa que tanto durante la guerra, como en tiempos de paz, existían personajes que se aprovechaban de las circunstancias para mejorar sus condiciones de vida y disfrutar de una posición social que en realidad no les correspondía.

La lectura de la obra de Jesús Castellanos deja la visión de un mundo en el que es difícil triunfar si no se acepta el juego del poder. Existen en esta sociedad las condiciones propicias para el surgimiento de una serie de tipos, que en un intento por conseguir un espacio en el orden social establecido, recurren a un modo de vida picaresco para lograr su objetivo. 
Notas

'Es necesario recordar que, según J. A. Maravall, el pícaro surge a causa de una serie de factores económicos, políticos y sociales que se dan en un momento de transición en España. Aunque en condiciones diferentes, los personajes de esta obra se hallan viviendo en un momento de transición para la isla, donde después de años de coloniaje y lucha, se acaba de instaurar la república.

${ }^{2}$ Esta frase célebre dicha por Lazarillo permea toda la obra de La conjura.

${ }^{3}$ A través de toda la narración encontramos personajes como don Próspero Villarín que adoptan el papel de voceros de la sociedad y critican las acciones de Augusto o le aconsejan cuál es el mejor camino a seguir, según los cánones de la sociedad imperante.

${ }^{4}$ Esta escena le da al lector una idea más precisa de que en la sociedad imperante en la época prevalecían sobre todos los nobles actos, la conveniencia y los intereses individuales, y donde solamente quien sabía jugar bien sus cartas y mover los resortes adecuados, alcanzaría su meta.

${ }^{5}$ Al principio de la novela, Margarita se perfila como el elemento que mantiene el equilibrio entre el "yo" verdadero y el "yo" que actúa a tono con los patrones sociales establecidos. Esta idea se infiere especialmente del hecho de que ella, a pesar de la relación solidaria que tiene con su primo, lo culpa de la confrontación que éste tuvo con don Próspero, que representa el convencionalismo dentro del orden social.

${ }^{6}$ Recordemos que el pícaro no quiere cambiar el orden social. No es un rebelde. Él solamente quiere aprovecharse de los aspectos negativos de la sociedad para subir en la escala social.

7 Según José A. Maravall, dos de los rasgos comunes a todos los pícaros son el deseo de ascender en la escala social, y el tratar de conseguirlo por métodos que no caben dentro de lo establecido. De acuerdo con este postulado, el hecho de que un personaje se encuentre en una escala social más o menos alta, no lo excluye de ser un tipo picaresco, si en él se observa un deseo de subir o mejorar de manera deshonesta y recurriendo a métodos fuera de la moral.

${ }^{8}$ La palabra pica-pleitos, sinónimo de abogado de baja calaña, es adecuada para calificar a este personaje. También, ese estar en todos los lugares y saberlo todo, característica de Morell, es un rasgo de este tipo. 
${ }^{9}$ Este personaje, según se caracteriza al principio, es un ejemplo del tipo de la coqueta, incluido en Los cubanos pintados por sí mismos.

${ }^{10}$ Aunque la posición de "querida" no sea muy edificante, para alguien que lo que busca es acomodarse y subir en el orden social, dejar de trabajar para tener una casa y un hombre que la mantenga, ya es un paso hacia arriba. Muchas pícaras del barroco eran las queridas de hombres de una clase social más alta.

"No debemos olvidar que desde los inicios del tipo celestinesco, se observan en los personajes ciertos rasgos, como el fingimiento, las trampas, las burlas, la mala vida, etc., que también son parte de la caracterización del arquetipo del pícaro, aunque ya modificados y puestos bajo condiciones diferentes.

${ }^{12}$ Este personaje, por su condición de delincuente, nos lleva a asociarlo con los pícaros barrocos, como el don Pablos de Quevedo.

${ }^{13}$ Éste es otro rasgo de la novela picaresca. El protagonista busca una excusa para contar su vida, aunque aquí la pregunta sea más bien reflexiva y una manera de justificar una posición poco patriótica. 
Capítulo Quinto. Personajes picarescos en la narrativa de Miguel de Carrión.

Miguel de Carrión (1875-1929), médico, pedagogo y periodista, es considerado por la crítica como "[. . .] uno de los novelistas más eminentes de Hispanoamérica" (Remos, Proceso histórico 271), y como el máximo exponente de la novela psicológica en la narrativa cubana de la primera generación republicana. De él ha dicho Juan J. Remos "[. . .] que es un artista del relato, pensador y analizador (y que) demuestra en sus novelas haber sorprendido el misterio del mecanismo más íntimo de la fisiología social y de la anatomía moral [. . .]" (Proceso histórico 271). Su obra "[. . .] se caracterizó por un pesimismo de aliento social, por una visión escéptica y amarga [. . .] (además de por) [. . .] una penetración punzante en los problemas humanos y en particular en los conflictos de la mujer en aquella sociedad" (Alvarez 18). La narrativa de Carrión, que presenta una amplia perspectiva social de las dos primeras décadas de la república, está escrita en un estilo realista y naturalista, y en la misma se advierten las influencias de algunos narradores europeos de la época, como Zola y Guy de Maupassant. Algunos críticos como Marcelo Pogolotti consideran que Carrión "presenta ciertos visos de precursor al rozar el tema de la represión sexual, tan ampliamente tratado después por los novelistas seguidores de las doctrinas de Freud" (58). Otro aspecto 
interesante del escritor es su "[. . . ] indudable capacidad para la pintura de personajes y pasiones y para la aprehensión de realidades sociales [. . . ] que caracterizaban a la Cuba de su época [. . .]" (Toledo Sande, "Prólogo" El milagro 11).

Su narrativa la constituyen cuatro novelas: El milagro (1903), Las Honradas (1918), Las Impuras (1919) y La esfinge (1961)'. Además escribió unos relatos breves que están reunidos bajo el título de $L a$ última voluntad (1903). El milagro es "[. . .] una preciosa novela, en la que se deja sentir la influencia, en la técnica, de Blasco Ibáñez, [. . .] pero de Nietzsche, en el pensamiento" (Remos, Proceso histórico 270). En su tiempo resultó ser una novela de tesis bastante atrevida, al presentar el drama íntimo de un seminarista que se entrega al amor y la vida laica. En esta novela se propone el autor "la redención del espíritu humano que va de la fe a la razón, pasando por el instinto y llegando al nivel ecléctico en que el corazón no es ni epicúreo ni cristiano, sino simplemente humano" (Remos, Historia 3: 292). Las honradas y Las impuras, las dos novelas que le aseguraron a Carrión un lugar importante en la literatura cubana, "[. . .] tienen un tema común y una misma preocupación. Tratan del conflicto espiritual de una mujer en lucha consigo misma y con los cánones de la decencia y la falsa moral dictados por la familia y la sociedad" (González La novela 32). Por su parte, La esfinge es "otro intento de Carrión por penetrar en el mundo psíquico de la mujer [. . .]" 
(Bueno, Historia de la Literatura 359), que relata la historia de una mujer casada con un hombre que la humilla constantemente y quien solamente busca su dinero y su cuerpo. Por último, los cuentos que forman el volumen de La última voluntad, como la mayoría de las novelas, están enmarcados dentro de la tendencia naturalista, y en ellos el autor demuestra su interés por los temas psicológicos.

\section{Las honradas.}

Esta novela es la primera de las dos que componen el díptico narrativo de Miguel de Carrión. Ésta es considerada por muchos como su obra maestra. De ella ha dicho Juan J. Remos que "es su obra máxima [. . .]; obra en que palpita lo humano y lo artístico; obra que puede figurar al lado de cualquiera de los altos exponentes de la novela naturalista, y en la que se cumple, como en pocas otras de su caletre, la tendencia a hacer de la novela un trabajo científico experimental" (Historia 3: 293). Por su parte, Enrique J. Varona alega que Las honradas es una "gran novela, porque en su rápida sucesión de cuadros vigorosamente trazados, ha hecho destacar figuras tan vivas, tan humanas, que las sentimos sentir, las oímos pensar y que nos serán para siempre conocidas." (Citado en "Prólogo" Las impuras 9)².

Las honradas es la historia de una joven mujer "[. . .] que tiene, según ella, la desgracia de pensar mucho y que a fuerza de hacerlo y de 
sufrir ha logrado que sus ideas acerca del bien y del mal se hayan embrollado en su cerebro" (Remos, Historia 3: 293). La obra está estructurada a manera de confesión de la propia protagonista, dedicada a su hija, para que cuando sea mayor, conozca la verdad de la condición femenina y su situación en la sociedad. Es ésta una novela de personajes, y al realizar un estudio de la tipología que presenta, se observa que la misma ofrece una amplia gama de tipos, especialmente femeninos, que viven y se desenvuelven en una sociedad, que según se perfila en el ambiente dado en la narración, obligaba, en muchos casos, a sostener falsas posturas donde prevalecía la hipocresía. Dada la educación y las tradiciones imperantes en la sociedad de la época, muchos de estos personajes adoptan un comportamiento y una filosofía de vida picarescos para mantener una aparente imagen de dignidad y honradez.

A través de todo el texto permea la idea de que se está en presencia de un mundo donde las mujeres llevan la peor parte. La perspectiva de la sociedad que presenta Carrión, a través de la confesión de Victoria, es una donde se imponen una conducta moral y unas tradiciones, especialmente relacionadas con el comportamiento sexual femenino, que las fuerza a actuar de un modo picaresco. En aquella sociedad, la mujer debía permanecer sumisa, casta, resignada a los engaños del marido, a la vez que escondía sus naturales apetitos sexuales. Esto lo aprendían desde niña, según lo hace patente Victoria al 
final de sus confesiones cuando transcribe la coplilla que cantaban su hija y las demás niñas, y que cuenta cómo una chiquilla es llevada a un matrimonio sin amor por su propia madre, y cómo el marido se le escapa a media noche para ver a su amante. El contenido de la canción infantil llena a la protagonista de zozobra y angustia, al pensar que su hija será otra víctima de ese mundo que la llevó a ella a un comportamiento indecoroso que marcó su vida para siempre y se debate entre la posibilidad de educarla como víctima o como vengadora.

Por otra parte, esta misma educación, dictada por el discurso del poder masculino, tenía también un efecto negativo en el carácter de los personajes masculinos, de manera que ni aun los mejor intencionados, como Joaquín el marido de Victoria, eran capaces de comprender la verdadera psiquis femenina y adoptar una actitud más acorde con la misma. Se hace evidente que en esta sociedad prevalece una educación que fija un patrón de conducta sexual y que, por lo tanto, impone limitaciones al comportamiento y a la expresión de los verdaderos sentimientos del individuo. Como resultado, el individuo adopta una conducta hipócrita para poder mantener las apariencias de una respetabilidad que se basa en la inhibición de los instintos sexuales del ser humano. Puede afirmarse que la adopción de una actitud picaresca ante esta situación es la única alternativa que encuentra el individuo que 
intenta encontrar un equilibrio entre esa respetabilidad moral y la satisfacción de los deseos reprimidos.

Dentro de la tipología que se presenta en Las honradas se encuentran personajes con diferentes tipos de actitud con respecto al comportamiento sexual. Entre los personajes femeninos algunos mantienen la respetabilidad a costa de domeñar sus instintos naturales, convirtiéndose en víctimas de los patrones sociales establecidos. Estos personajes son en algunos casos, personajes "conciencia", y tienen el efecto de reprimir la sexualidad de otros personajes. ${ }^{3}$ Otros desafían abiertamente a la sociedad con su comportamiento sexual, y se niegan a ser víctimas. ${ }^{4}$ Finalmente, se encuentra el último tipo de personaje. El que sufre "la caída", o sea, el que al principio se comporta de acuerdo con los cánones establecidos pero luego, como resultado de una serie de represiones y circunstancias, termina cediendo al juego de mantener la respetabilidad, aunque solamente de manera superficial, mientras en secreto satisface sus instintos sexuales. ${ }^{5}$ En cuanto a los personajes masculinos, puede decirse que los mismos siguen el patrón de comportamiento establecido, aunque en algunos casos este comportamiento puede relacionarse con una filosofía de vida picaresca. La mayoría de los personajes de Las honradas están interesados en mantener esta respetabilidad, aunque ésta solamente sea, en algunos casos, de fachada. La moral sexual imperante está tan arraigada, que 
cuando se infringe se hace de manera que el acto quede encubierto, hecho éste que representa una filosofía de vida picaresca.

Debido a la importancia que Carrión concede al tema de las relaciones sexuales en su obra, el comportamiento picaresco de los personajes está, en la mayoría de los casos, vinculado con ello. Sin embargo, hay algunos que también manifiestan un comportamiento picaresco en situaciones donde las relaciones sexuales son solamente una realidad tangencial.

Victoria, la protagonista de la obra, es el personaje que mejor ejemplifica la metamorfosis que puede sufrir una mujer que, durante gran parte de su vida, se ha creído obligada a reprimir sus instintos sexuales para conservar su honradez, y así cumplir con los cánones de la moralidad social imperante. La frustración y la infelicidad la llevan a adoptar una filosofía de vida picaresca, en cuanto a lo sexual. De esta manera, la honrada se convierte en impura.

En realidad, Las honradas no es otra cosa sino el análisis que realiza Victoria de su propia metamorfosis psicológica. Los títulos de las tres partes de la novela hacen referencia a los tres momentos más importantes de dicho proceso, y pueden compararse con las etapas de la vida de un pícaro, que se inicia con la inocencia/ilusión, sufre un proceso de aprendizaje que lo hace convertirse en pícaro--muerte de la ilusión--y, 
al final, logra el éxito cuando actúa de acuerdo con la nueva filosofía: la picaresca, renacimiento de la ilusión. ${ }^{6}$

Victoria inicia su relato con su niñez. Y no es de extrañar que ya, desde el comienzo de sus memorias, haga referencia a una educación severa. Es, precisamente, la educación que recibió en la temprana edad la causa principal de muchas de sus falsas percepciones en cuanto al papel de la mujer en la sociedad, especialmente con respecto al amor y al sexo. Como parte de aquella educación --en exceso celosa de la inocencia de los niños--ella y sus hermanos vivían aislados: "[. . .] vivíamos durante el día recluidos en la casa, sin que los niños de la vecindad vinieran a ella ni nos permitieran salir a jugar con ellos" (Las honradas 30), vigilados siempre por la madre: "Mamá quería tenernos siempre al alcance de su vista" (Las honradas 30), y sin asistir a la escuela. Fueron sus maestras su madre y la tía Antonia "[. . .] enemiga de los colegios, donde, según ella, se corrompía a la juventud" (Las honradas 35). Tampoco se les permitía a los niños aprender a través de la observación del mundo y de la naturaleza. Al respecto Victoria comenta: "En casa no había parejas de animales, los criados eran antiguos y de absoluta confianza, y mis padres no se hubieran atrevido a tocarse la punta de los dedos delante de nosotros" (Las honradas 36).

Sin embargo, es interesante señalar que desde el comienzo de la narración el lector percibe en el personaje de Victoria unos rasgos de la 
personalidad que pueden propiciar la transformación picaresca. Al establecer un paralelo entre su propio carácter y el de su hermana, la narradora lleva al lector a inferir que, una vez convertidas en mujeres, cada una de ellas adoptará un comportamiento diferente en el esquema social. Al describirse a sí misma, Victoria comenta que "[. . .] tenía un carácter más audaz [. . .]" (Las honradas 31) que el de su hermana; y luego, más adelante comenta: "[ . . ] la curiosidad [. . . ] ha sido el rasgo más saliente de mi temperamento" (Las honradas 31). Es precisamente ese rasgo el que la llevará a descubrir por otros medios lo que la educación familiar le escondió. Otro rasgo de su personalidad que Victoria destaca es su indocilidad, y admite que "[. . .] desde muy temprano en mi niñez, aquel espíritu indócil empezó a entrever la injusticia con que están distribuidos los derechos de los sexos" (Las honradas 32). A pesar de su ignorancia en cuanto a temas sexuales se refiere, Victoria se había dado cuenta, siendo niña aún, de que en su mundo las mujeres y los hombres no tenían los mismos derechos, y que la sociedad tenía establecido un patrón de comportamiento aceptable para cada sexo.

No solamente influyeron en el comportamiento de Victoria adulta las ideas que le fueron inculcadas de pequeña sobre el papel de la mujer en la sociedad, sino también las percepciones que la crianza que recibió le hizo concebir respecto a su propio cuerpo y al sexo. Ella misma 
confiesa: "A los nueve años mis oídos no habían sido heridos por una sola palabra que turbara la serenidad de mi inocencia" (Las honradas 36). Es por unos comentarios de Graciela que Victoria empieza a sospechar que hay algo que ella desconoce con respecto a la sexualidad. Es éste un momento clave en la psicología del personaje, que confiesa que el mismo "[. . .] ha quedado profundamente grabado en mi memoria [. . . la crudeza conque se expresó aquella noche y lo que dijo, me habían hecho una impresión mucho más honda que todo lo que había oído hasta entonces" (Las honradas 36-39).7 A partir de este punto de la narración, se empiezan a observar en la pequeña Victoria rasgos que perfilan cierto comportamiento picaresco, aunque el personaje no se muestre como tal hasta que ya se ha convertido en una mujer casada. A pesar de que al principio duda sobre la veracidad de lo que le ha comentado su amiga sobre los matrimonios porque tiene a su madre por una mujer honrada y decente, incapaz de semejantes actos, su innata curiosidad y su espíritu inquisitivo la llevan a emprender una búsqueda de la verdad sobre el tema. ${ }^{8}$ Sin embargo, sabe que para poder descubrir lo que quiere tiene que adoptar una postura de fingimiento, de "hacerse la boba", si no quiere despertar sospechas. Esta situación en la que se encuentra el personaje, lo fuerza a un comportamiento de filiación picaresca. A Victoria su curiosidad, su necesidad de saber y comprobar la llevan por un camino que sabe no es compatible con la educación que le han dado, 
por lo tanto, tiene que fingir. Esta actitud puede considerarse como una parodia, si no del honor, de la honradez. Ella aparentemente acepta las reglas del hogar, pero las burla "[. . .] espiando constantemente a los demás y a cuanto podía encerrar la clave del enigma, aun en los momentos que más distraída parecía" (Las honradas 39). Una de las características picarescas que adquiere Victoria en esta época es la astucia. Refiriéndose a las observaciones que hacía de su hermano, dice que "acechaba sus descuidos, con astucia de gata [. . .]" (Las honradas 39). A pesar de la vigilancia de la madre, se produce un hecho que acaba definitivamente con la inocencia de Victoria y sus hermanos: una gata que vivía en la casa pare un gatito delante de los niños.

Es interesante destacar que a pesar de que Victoria se propone descubrir todos los misterios que para ella encerraba el sexo, ella tenía una concepción equivocada de éste, y así lo manifiesta: "Mis ideas acerca de ciertas interioridades del cuerpo eran confusas y estaban relacionadas con sentimientos de repugnancia y de vergüenza, de los cuales eran inseparables" (Las honradas 38). Debido a esto, cuando pierde la inocencia, en un intento de mantener la reputación de joven virtuosa, opta por el pudor: "al caer uno a uno los pétalos de la inocencia, se iba abriendo más lozana la rosa del pudor" (Las honradas 42). Así, poco a poco, Victoria se va convirtiendo en un personaje proteico que va 
adoptando diferentes posturas ante cada una de las situaciones que tiene que enfrentar, y que vive una vida donde todo es apariencias:

Empezaba a ser mujer, sin que nadie me lo hubiera enseñado. Quería saber siempre más, pero aprendía a disimular mis impresiones. De ahí que ni mi madre ni mi tía, a pesar de la suspicacia con que nos examinaban constantemente, llegaran a sospechar el más insignificante de mis descubrimientos. Nunca, en efecto, delante de ellas, y mientras estudiaba uno por uno todos sus ademanes y espiaba sus palabras para unirlas a mi colección, mis ojos brillaban con más serena expresión de candor, ni se abatieron con mayor modestia sobre las baldosas del piso. (Las honradas 42)

Con motivo de la guerra, la vida de Victoria toma un giro inesperado. La familia decide emigrar a los Estados Unidos, y en esta nueva etapa de su vida Victoria entra en contacto con otras jóvenes cuyas ideas sobre el amor y el sexo son totalmente diferentes a las que ella tenía. Interna en un colegio de monjas y fuera del control de la madre, la joven continúa descubriendo los misterios de la vida. El propio personaje reconoce que su entrada al microcosmos del colegio fue como una iniciación para ella en los misterios que la educación familiar le mantuvo 
escondidos. Al salir de allí, afirma que: "Lo sabía teóricamente todo [. . . ]" (Las honradas 59).

Es interesante señalar que durante su estancia en el internado, Victoria y su grupo de amigas manifiestan, en algunos momentos, un comportamiento que está muy cercano al de algunos pícaros clásicos, no, por el hecho en sí, sino por la forma de actuar. Victoria comenta en su recuento que

en el colegio [. . .] estaban prohibidos los polvos de arroz y los perfumes. Sin embargo [.. .] (ella y sus compañeras encontraban) [.. .] la manera de burlar en parte estas prescripciones del reglamento, y en esto, como en muchas circunstancias, "nuestra hermandad" ponía en juego todos sus medios y desempeñaba un papel muy importante. (Las honradas 62$)^{9}$

Esta acción, aunque inocente, denota en el personaje un comportamiento que rompe con el orden establecido y lo sitúa, de cierta forma en la marginalidad. Victoria, como Lázaro o don Pablos, va desarrollando habilidades picarescas como medio para burlar las reglas del orden establecido.

A pesar de que al regresar a La Habana Victoria no era ya una niña inocente, sino una joven que, en teoría, había descubierto los secretos del amor y el sexo, las enseñanzas de su madre habían hecho tanta mella 
en su mente que según sus propias palabras, "[. . .] el amor personalizado en una criatura de carne y huesos, [ . . ] (le) [. . .] producía una inquietud muy cercana al horror" (Las honradas 92). Ante el hecho inminente de que su hermana pronto tendrá novio y se casará, la reacción de Victoria hace patente la lucha interior que la atormenta. Al recordar que una monja del internado le dijo que ella algún día se casaría, trataba de verse involucrada en una relación matrimonial y de adivinar cuáles serían sus emociones en esta situación; sin embargo, no se atrevía a llegar muy lejos. Piensa: "Allí estaba lo intangible, lo prohibido, lo que me producía una extraña y profunda aversión nunca bien razonada, y que sin embargo, me atraía con la vaga solicitación del abismo" (Las honradas 92). Quizás sin darse cuenta, Victoria expone con esas palabras su dualismo con respecto a las relaciones sexuales. Se perfila en ella la mujer que se debate entre la satisfacción de sus instintos naturales y la obligación de mantener un lugar decoroso ante la sociedad.

Es importante destacar que el pudor de Victoria era excesivo, y se proyecta como una manera de acallar su propia sensualidad. En numerosas ocasiones el personaje comenta las reacciones que tenía con relación a su propia desnudez, ya fuera en presencia de otros o en soledad. El lector de ellas infiere que existe en el personaje una gran confusión y una lucha interna por mantenerse respetable, de acuerdo con 
los parámetros establecidos por la sociedad. Victoria a veces esconde su cuerpo, lo rechaza, y otras se regodea en él:

Aun estando sola me producía cierta vaga emoción el contemplar mi desnudez. Un pie sin media [. . .] aunque fuera mío, me repugnaba [. . .]. En cambio me gustaba verme las piernas, después de calzada, y estaba orgullosa de tenerlas gruesas por arriba y finas por abajo, con un desarrollo "que engañaba". (Las honradas 136)

Este comportamiento de la joven Victoria sugiere un desajuste de la psiquis, y así mismo lo reconoce de adulta: "Hay tal número de contradicciones en mis sentimientos de la juventud, que si los anotara todos ahora, yo misma acabaría por creer que he sido una loca y que acaso lo soy aún" (Las honradas 136-137). Este desajuste, causado por la rigidez de la educación y las presiones de la sociedad, es otro factor que contribuye al proceso de la caída de Victoria. El personaje se debate entre adoptar un papel respetable y la satisfacción de su propia sensualidad. Sin embargo, como no encuentra una solución para su conflicto que esté de acuerdo con el orden establecido, tiene que recurrir al comportamiento picaresco. Es interesante notar que el personaje va cayendo poco a poco, y sin casi darse cuenta. No hay en Victoria una filosofía picaresca consciente, sino una metamorfosis gradual e inconsciente que culminará con la caída final. 
Después del matrimonio de su hermana, Victoria "empezaba a sentir la necesidad de cariño" (Las honradas 137). Llega a la conclusión de que necesitaba casarse, y confiesa: "[. . .] no me repugnó la idea" (Las honradas 137). Surge así en Victoria la mujer convencional, criada para esposa y madre, no por amor, sino por necesidad, por cumplir con un papel en la sociedad.

Como la propia Victoria señala, el único posible candidato a marido para ella era Joaquín Alvareda, un hombre "[. . .] que no me desagradaba y que venía a vernos una o dos veces al mes [. . .]" (Las honradas 137). Sin embargo, Victoria cuestiona sus sentimientos hacia Alvareda: ¿Me gustaba Alvareda para casarme con él? Me parecía dulce simpático, pero nada más. Entre todos "me disgustaba menos". He ahí mi sentimiento exactamente expresado. En realidad, mi corazón no había latido por nadie todavía, con ese latido instantáneo y apasionado que se describe en las novelas. Mis sueños de amor no se habían hecho carne, y no se parecía mucho a aquel muchacho tímido y serio que sólo me devoraba con los ojos cuando creía que no lo observaba. Sin embargo, papá y mamá hacían de él grandes elogios [. . .]. Acabaron por hacerme pensar en él, de vez en cuando [. . .]. En la sed que empezaba a devorarme, Joaquín Alvareda era la única fuente accesible. (Las honradas 137-138) 
Hay dos episodios en la vida de la muchacha que ilustran las dos vertientes de su pensamiento. Mientras que Victoria piensa que Alvareda representa su única posibilidad de matrimonio, se enamora de un actor de teatro. Este enamoramiento es indicio de las emociones que estaban ocultas en el alma de la joven y que a veces pugnaban por salir a la superficie. Lo que siente al ver al actor descubre un nuevo aspecto de su personalidad:

Vial cómico una noche en una obra moderna, de americana gris en un acto y de frac en otro, y perdí el interés por la representación sólo por mirarlo a él. Jamás ningún hombre me había hecho una impresión parecida: lo cual me daba una idea aproximada de lo que es el verdadero amor, el de las novelas [. . .]. Cuando lo veía aparecer en escena se me enfriaban las manos y sentía como si el corazón me martillara en el pecho. Tengo la seguridad de que si lo hubiera visto aparecer delante de mí, en el palco, hubiese escapado de allí a todo correr; pero por la noche, con la imaginación, me complacía en tenerlo cerca, y aun sentir que sus brazos me oprimían sin mucha violencia... (Las honradas 141-142)

Ésta es la Victoria genuina, la que sin ningún tipo de represión expresa sus sentimientos. Sin embargo, un incidente, que casi puede juzgarse de 
insignificante, hace que Victoria vuelva a su comportamiento de joven respetable que oculta sus íntimas sensaciones y se preocupa por "el qué dirán": un dentista la besa mientras la atendía en su consultorio. Este beso provoca una reacción extrema en la joven, que llega a acusarse a sí misma de lo ocurrido:

Durante algunos días quedé como aturdida, del mismo modo que si hubiese recibido un golpe en el cerebro. La humillación de sentirme tratada como una de esas muchachas locas que se dejan besar por los doctores me volvió a la realidad, haciéndome aborrecer los sueños. No creo que en la mujer haya un sentimiento más torturador que el despertado por esta frase: "Qué habrá pensado de mí", base de más de las dos terceras partes de nuestra virtud. Pensé que yo había provocado la grosera acometida con mis necedades románticas; y me atormentaba horriblemente la idea de que algún día pudiera encontrarme en cualquier parte con el dentista. Y lo peor es que tenía que disimular para que no advirtiesen en mi casa que algo grave me había sucedido. Excuso el decir que no volví a pensar una sola vez en el cómico, a quien acusaba indirectamente de ser el causante de mi afrenta. (Las honradas 144) 
Después de este suceso, Victoria sucumbe a lo que ella misma llama la "insidiosa presión del medio, que acaba de hacer imposible la elección de un marido por una joven" (Las honradas 151). Se convence a sí misma de que el mejor camino a seguir es el matrimonio con Alvareda. Con este comportamiento lograría la respetabilidad en la sociedad, y pondría una barrera a su comportamiento menos convencional que la llevaba a "[. . .] andar imaginando irrealizables amoríos [. . .]" (Las honradas 145); sin embargo, no se sentía segura ante el hecho, y ni siquiera está segura de amar al hombre. Cuando su amiga le pregunta si quiere a Alvareda, contesta: "Creo que sí" (Las honradas 152).

Finalmente, ante la declaración de amor del hombre, Victoria accede y ella misma reconoce que su conducta es el resultado de un querer obedecer un patrón establecido:

Hice lo que me había chocado en Alicia, que fue "amiga" hasta una noche y "novia" después, sin una transición aparente. Pensé mucho en él, hablé de él a todas horas y me abandoné a su cariño sin recelos ya, puesto que se trataba de algo santo y permitido que habían hecho mis abuelas y que harían seguramente mis nietas. (Las honradas 154)

A pesar del comportamiento digno que manifiesta el personaje de Victoria en esta etapa de su vida, existe una veta picaresca. La filosofía picaresca conlleva el arte del disimulo, y Victoria disimula hasta creer que 
su comportamiento es sincero. Sin embargo, hay en su forma de actuar, un fingimiento, un adaptarse a las circunstancias. Es cobarde, no lucha. Busca un acomodo en aquella sociedad, y un matrimonio aceptado por la sociedad se lo proporciona. Se sabe víctima de unas circunstancias, pero no se rebela, más bien, hace todo lo posible por ahogar cualquier intento de rebeldía.

La visión de Victoria sobre las relaciones sexuales es la que determinará en el futuro su "caída", y la convertirá en una honradaimpura. Victoria enfrenta la realidad de su matrimonio con miedo; la consumación del mismo era para ella "[. . .] una prueba dolorosa" (Las honradas 157). A pesar de eso, trata de acallar sus emociones y tranquilizarse: "[ . . ] tenía la seguridad de que me llevarían suavemente, casi como si tuviera los ojos vendados, a la revelación del misterio tendido y secretamente anhelado, y ni quería pensar en eso siquiera" (Las honradas 157). Sin embargo, Victoria se equivocó, la dinámica de la relación sexual entre ella y su marido se ve afectada, desde el comienzo, por la inexperiencia de ambos y por las falsas percepciones que poseen de la misma, sobre todo Victoria.

No cabe duda de que en el relato que hace Victoria del viaje de camino a su casa después de la boda, el sentimiento que la domina es el miedo. Rechaza cada contacto que inicia su marido, si no físicamente, sí íntimamente. No es el de Victoria el comportamiento de una mujer 
deseosa de entregarse al amor y la pasión del marido, sino el de quien se somete a cumplir con las normas, el de quien doblega sus emociones y se convierte en objeto pasivo del otro, y se resigna a sufrir con un acto que no desea: "Sabía que no iba a experimentar el menor goce, y estaba resignada a sufrir lo que fuera necesario" (Las honradas 165). Así se inicia Victoria en su vida sexual, y al hacer un recuento de la noche de bodas, el episodio parece ser más una batalla entre dos enemigos que la consumación física del amor entre una pareja de recién casados:

La idea del deber se me impuso, surgida de no sé qué rincón de mi espíritu donde duermen los mandatos ancestrales que prescriben a mi sexo la humildad y la sumisión. Tenía además otro propósito más egoísta: deseaba llegar pronto al fin y quedar tranquila. Pero aquello se prolongó horas, durante las cuales asistí, pasiva y resignada a mi martirio. Por mi natural conformación o por la torpeza de Joaquín la lucha fue larga, tenaz y encarnizada. La acepté, sin exhalar una queja, sin protestar una sola vez. Y pude hacer una observación desconsoladora: el hombre es cruel en el amor, y su deleite aumenta en la proporción a los padecimientos que ocasiona. Harto claramente me lo dijeron las frases sueltas y las ingenuas exclamaciones de mi marido, en las cuales, si había algún rasgo de piedad, era sólo para 
exhortarme a la pasividad que facilitaba su obra... (Las

honradas 166-167)

Esa primera experiencia tan negativa fue el detonante que propició la caída moral de Victoria.

Es interesante destacar que aunque Victoria se entrega a su marido por obediencia, se siente sucia ante sí misma, quizás porque intimamente siente que ha traicionado sus propios sentimientos: "Lo que me había dejado hacer, sin deseo y sin goce, me rebajaba a mis propios ojos" (Las honradas 167). Por otra parte, siente orgullo, cuando la sirvienta la llama "señora". Una vez más, en Victoria se debaten sentimientos contradictorios: para llegar a aquel título ha tenido que someterse, ser como una esclava a quien el amo toma cuando le apetece sin tener en cuenta sus sentimientos. Victoria es ahora una "honrada" a los ojos de la sociedad, pero nunca antes se ha sentido más sucia y más impura. Sin embargo, acepta el juego social y adopta su nuevo papel, el de mujer casada: "Me acostumbré como nos habituamos todas a la vida que nos imponen, sujetas a la obediencia desde que nacemos ¿No nos preparan escrupulosamente para eso? A los diez días de casada era dócil y procuraba someterme de buen grado a mi deber" (Las honradas 176). Las que otorgan la aparente estabilidad del matrimonio son la obediencia y sumisión de Victoria, y su capacidad de fingimiento. 
Guiada por las ideas que había recibido de su madre y reafirmadas éstas por otras mujeres casadas que Victoria conoce durante su estancia en el ingenio, llega a la conclusión de que "El amor de una esposa es siempre púdico, como el que yo profesaba a Joaquín; y el que él deseaba que yo sintiera era el otro, el de las queridas" (Las honradas 241). Según va pasando el tiempo, Victoria se va aferrando más a una idea errada de la honradez y la respetabilidad en la mujer. Su frialdad de comportamiento en las relaciones sexuales da como resultado que el marido se vaya alejando de ella, convencido de que el amor que su mujer siente por él es un amor filial y no lo que él desea. Llega a reprocharle que se entregue solamente por cumplir con el deber de esposa, y no por satisfacer sus propios deseos de mujer enamorada.

El deterioro de las relaciones de Victoria y Joaquín llega a su punto culminante cuando éste se ausenta de la ciudad durante toda la zafra. La ausencia de Joaquín y la consiguiente soledad de Victoria contribuyen de manera definitiva a propiciar la transformación de ella en pícara. A pesar de que las reglas del orden establecido pesan muchísimo en la conciencia de Victoria, y de que hay en ella una voluntad de ocupar un puesto en el grupo de las "honradas", su insatisfacción sexual, su frustración, su infelicidad, y quizás su propia sexualidad, la arrastran por el camino de las "impuras", y cae, casi sin darse cuenta, en la redes del seductor Fernando Sánchez del Arco. A partir del instante en que Victoria conoce a 
Fernando, se inicia el proceso que la convierte, definitivamente, en un personaje de filiación picaresca.

A pesar de que la relación entre ambos personajes se inicia de manera fortuita, la ocasión se debe a una desobediencia, si bien inocente, de Victoria. No se sabe qué móvil la lleva a ir ella a cumplir con el encargo que su marido le había pedido fuera realizado por otra persona, pero lo cierto es que un comportamiento inapropiado por parte de ella, desencadena toda la serie de hechos que la llevarán al adulterio. Aún sin conocer a Fernando, Victoria siente una atracción hacia él, a la vez que reconoce que ha cometido una falta: "Quería dominar la emoción que me inspiraban la solemnidad de aquella oficina y la idea de que pronto iba a aparecer ante mí el hombre a cuya voluntad estaban sometidos todos aquellos empleados silenciosos [. . . ]. Casi me arrepentía de la locura de haber ido en lugar de Julia" (Las honradas 284). Al recordar el momento en que vio a Fernando por primera vez confiesa: "Aquella aparición acabó de trastornarme [. . .]" (Las honradas 284). Quizás de manera inconsciente, desde este momento, Fernando se convierte en una obsesión para Victoria.

A partir del encuentro con Fernando es evidente un cambio en la psiquis de Victoria. Empiezan a surgir en ella, deseos de tener riquezas, comodidades. Desarrolla una poderosa conciencia del cuerpo. Se percibe en ella una "alegría de vivir", que hasta ahora no había demostrado. 
Cuando el recuerdo del hombre viene a su mente, lo rechaza, quizás en un esfuerzo por no aceptar lo que está sintiendo: "A cada momento venían a mi mente los recuerdos de la víspera, y los rechazaba dulcemente, como contrariada por su persistencia" (Las honradas 293). Este mismo rechazo, puede considerarse parte del comportamiento picaresco. Victoria sabe que lo que siente conspira contra lo establecido, y por eso trata de acallar sus emociones. Desea ser la amiga que Fernando le propone, pero en aquellos tiempos una amistad entre un hombre y una mujer casada ponía en entredicho su respetabilidad. Todos los razonamientos son inútiles porque, en lo que puede señalarse como una parodia del honor y la honradez, Victoria sigue un comportamiento intachable--al menos por un tiempo--, mientras disfruta íntimamente reviviendo los momentos que vivió junto al hombre:

Empezaba a experimentar claramente los síntomas de una enfermedad del espíritu, que me llevaba a gozar y sufrir reviviendo sucesos acaecidos, con rasgos y detalles que resultaban a cada nueva evocación más brillantes; volviendo siempre a los mismos en una obsesión persistente, que excluía todo pensamiento extraño y todo razonamiento desapasionado. (Las honradas 296)

Sin embargo, el personaje no encuentra nada censurable en estos sentimientos, mientras que los mismos no estén acompañados de 
acciones indecorosas. Cree que su condición de mujer honrada no se afecta con lo que ella misma llama " este juego mental" (Las honradas 298), pero no cabe duda de que en realidad, su comportamiento conlleva una doblez y un fingimiento. Por otra parte, el efecto que tienen los sentimientos provocados por Fernando afectan su relación con Joaquín, al confesar que le ha escrito a su marido una carta que lo sorprenderá porque en la misma se proyecta ella como una mujer enamorada que tiene la necesidad física de su hombre. Fernando ha despertado en Victoria la necesidad de satisfacer sus reprimidos instintos sexuales $y$, al no poder hacerlo con él, los canaliza hacia su marido, puesto que así se mantiene honrada.

Una vez iniciado el sutil asedio de Victoria, el proceso continúa de la misma manera. Victoria, a veces es cómplice de Fernando y acepta sus falsas protestas de amistad; otras veces, lo rehuye porque se da cuenta de que es víctima de las manipulaciones de un hombre de mundo; sin embargo, sigue alimentando íntimamente los sentimientos que el mismo despierta en ella, hasta que finalmente acepta los encuentros que con suma astucia ha propiciado el hombre en casa de la vecina de Victoria. Victoria empieza a llevar una doble vida que lleva implícita rasgos picarescos como la falsedad, la decepción, la infidelidad, la traición, la ingratitud y la mentira. Con el pretexto de aprender a pintar flores, pasa horas en la casa vecina, lugar donde se suceden frecuentemente los 
encuentros secretos con Fernando. Poco a poco, el hombre va tomando posesión de la voluntad de la joven que se deja llevar. La inminencia de su reunión con el marido en el ingenio y la consiguiente separación de Fernando, son las causas de la caída de Victoria, que termina convirtiéndose en amante del último. Al entregarse a Fernando, Victoria se siente realizada como mujer y en medio de su júbilo y satisfacción, culpa a la sociedad por el rumbo que ha tomado: "Había también allí no sé qué brote de amarga acusación contra los que habían torcido y echado a perder mi vida, impidiendo que legítimamente hubiera podido disfrutar los goces que ahora le robaba al adulterio" (Las honradas 333).

Una vez convertida en amante de Fernando, decide llevar una vida de fingimientos y disimulo, guardando el secreto de su pecado, y manteniendo aún su condición de mujer honrada hasta que pueda huir con el amante. Es curioso observar el cambio que se opera en Victoria sobre los valores morales, ya que después de haber sido poseída por Fernando, decide que "no sería traidora, no engañaría a Joaquín [. . .]" (Las honradas 333), cuando en realidad ya lo había hecho. O sea, que para ella, mientras los sucesos se mantuvieran ocultos, y ella no abandonara a su marido para irse con el otro y no mantuviera relaciones con los dos simultáneamente, no existía la traición ni el engaño. El lector presencia paulatinamente la transformación de Victoria, que acepta cualquier juego, cualquier condición poco respetable para continuar su 
relación con el amante, mientras que se presenta dignamente a su familia y a su marido, llegando a utilizar a su hermana enferma como excusa para permanecer fuera de la casa y poder continuar los encuentros con el amante. Su capacidad de manipulación en esos momentos no tiene límites. Consigue que su propia hermana le escriba al marido rogándole que le permita quedarse más tiempo en La Habana debido a una operación, pero ella misma confiesa su verdadera intención: "Mi propósito era únicamente ganar tiempo, mientras Fernando se decidía a resolver de una vez nuestra situación" (Las honradas 339). Y acepta sin rodeos su forma picaresca de vida: "Entretanto, mi vida continuaba desenvolviéndose entre mentiras que urdía sin cesar para justificar mis citas" (Las honradas 339). Ha perdido la vergüenza y los escrúpulos de mujer respetable: "Ya no me molestaba la conciencia de mi falta, puesto que al abandonar a un marido que no había sabido hacerse amar como se aman los hombres y las mujeres, mi única acción consistía en haber atrapado la felicidad al paso" (Las honradas 340), y se justifica, como lo hacen la mayoría de los pícaros, culpando a los demás de sus propias faltas.

Como producto de la relación con Fernando queda embarazada, y si bien al principio sus valores morales la llevan a rechazar la propuesta de Fernando de abortar como condición única para continuar su vínculo, después, por las influencias de Úrsula, su vecina, decide realizar el 
vergonzoso acto. Victoria evita con el mismo tomar el camino de las perdidas, aceptando el de las hipócritas, o sea el más en consonancia con la filosofía de vida picaresca. Sin embargo, todavía queda en Victoria un resquicio de conciencia: "deshonrada por el adulterio y mancillada por aquellas lindas manos criminales que acababan de hurgar en mis entrañas, no podría ver más a Joaquín; lo había determinado irrevocablemente la rectitud de mi corazón que todavía no había muerto por completo" (Las honradas 375), que desaparece definitivamente un poco más tarde, aconsejada por su amiga Graciela, quien al contarle sus propias aventuras amorosas extramatrimoniales, le señala la posibilidad de continuar siendo una dama respetable junto a su esposo, a pesar de las faltas cometidas. De esta manera, y como resultado de una visión picaresca, Victoria se convierte en el binomio honrada-impura, que tipifica al personaje.

Quizás el personaje que más claramente pertenece al grupo que Victoria llama de "las víctimas" es Alicia. De la misma manera que en la primera, desde pequeña, se observan rasgos de la personalidad que habrían de llevarla, mediante una metamorfosis psicológica, a una conducta picaresca, en la última se ven perfiladas, desde el principio, unas características que llevan al lector a relacionarla con el tipo de mujer que sabe exactamente cuál es el papel que le toca representar en la sociedad si quiere ser considerada una mujer "honrada". Desde la infancia 
es sumisa y acepta las acciones de los demás con espíritu resignado. Ante los destrozos que hacía su hermano a sus muñecas, Alicia "[. . .] reparaba pacientemente el daño causado, y sonreía o lloraba en silencio" (Las honradas 32). Se esboza en esta niña la imagen de una mujer sacrificada que acepta su suerte sin, ni siquiera, quejarse abiertamente.

A pesar de lo que va aprendiendo con Graciela y sus compañeras de internado en Nueva York, Alicia mantiene una actitud poco curiosa e indiferente ante los temas sexuales. Sin embargo, no se puede precisar si esa indiferencia era real o, si en realidad, era una pose adoptada para cumplir con lo establecido, mientras reprimía sus íntimas emociones. La propia Victoria duda de la conducta que mantiene su hermana, ante la presencia del primer enamorado: "Alicia, con indiferencia real o fingida, permanecía de codos en la baranda y volvía la cabeza a un lado y a otro, mostrando perfecta naturalidad" (Las honradas 55). La actitud que adopta Alicia, desde muy joven, está guiada a dar una imagen de respetabilidad y honradez a los hombres que la tratan. Hasta su hermano Gastón lo señala en una ocasión: "[. . .] siempre fue muy seria, y ahora que es toda una dama me inspira mucho respeto" (Las honradas 74).

Cuando José Ignacio Trebijo empieza a cortejarla, y durante todo el noviazgo, el comportamiento de Alicia carece de espontaneidad y frescura. Todo parece indicar que ella se limitaba a representar, resignadamente, el papel que le tocaba. Al referirse a la relación de Alicia 
y José Ignacio en sus comienzos, y hasta llegado el momento de la boda, Victoria comenta: "Las cosas se llevaban [. . .], con todo el ceremonial de costumbre" (Las honradas 95). Después Victoria hace otro comentario del que se infiere una falta de emoción y una actitud poco auténtica por parte de Alicia en todo lo tocante a su relación con José Ignacio:

Fue un curioso cambio operado en veinticuatro horas. La víspera del matrimonio de Graciela, Trebijo era el amigo predilecto, por el cual se sacrificaban gustosamente las diversiones: al día siguiente era el novio con todos sus derechos, hasta el de exigir de ella que fuera coqueta por agradarle. En la mente de Alicia, como en la de mamá, las ideas debían de estar trazadas a cordel, como las calles de una ciudad nueva. (Las honradas 96)

Y cuestiona abiertamente las motivaciones que pudo haber tenido su hermana para casarse con ese hombre:

¿Lo amaba realmente mi hermana? He ahí algo difícil de discernir. No creo que Alicia se entregara a cálculos aritméticos sobre la fortuna de Trebijo, antes de aceptar su amor; [. . .] en Alicia no hubo más --me atrevería a jurarlo-que esa pasiva necesidad de ser amada, esa certidumbre de que están hechas para ser algún día esposas y madres que 
lleva dócilmente al matrimonio a las nueve décimas partes de las mujeres. (Las honradas 103-104)

Alicia, desde que formalizó su compromiso con Trebijo, "hacía lo que hacen todas las novias" (Las honradas 104). Cada día que venía el novio a visitarla, seguía una rutina, una especie de ritual con que el que debía cumplir. Al recordar esa conducta de su hermana, Victoria comenta:

Si en esto consistía el amor, amor era. Pero tengo para mí que no era a Trebijo sino "al novio" a quien se dirigían estas solicitudes; es decir, que cualquier otro hombre hubiera gozado de los mismos privilegios, si ese otro hombre hubiese llamado primero a las puertas de su corazón, despertando en éste el latente propósito de consagrarse a alguien que albergaba. (Las honradas 104)

Mientras es soltera obedece a la madre sin atreverse a cuestionar. Una vez casada, se somete a la voluntad del marido y se convierte en una esposa modelo, Es, a la vez, víctima de la moral imperante. Sufre una enfermedad que le ha contagiado el marido como resultado de sus aventuras con "las impuras", que podía haberle, incluso, causado la muerte. A pesar de todo, Alicia no se rebela; aun en el lecho de convaleciente, se preocupa porque su esposo esté bien atendido. Hasta en los momentos de más intimidad, Alicia adopta la posición de esposa 
abnegada y sacrificada: "En realidad mi goce consiste principalmente en ver a mi marido gozar, y en saber que soy yo quien le proporciona eso" (Las honradas 269). Con este personaje, el autor representa al tipo de mujer de su tiempo que, a consecuencia de un concepto falso de la moral y de la sexualidad femenina, se convierte en objeto sexual. Este tipo de mujer, una vez casada, vive en función de la visión masculina, prescindiendo de todo sentimiento y emoción propios.

Además de ser uno de los personajes "conciencia" que más influencia ejerce sobre Victoria, Graciela es el prototipo de la mujer "vengadora". Desde pequeña se perciben en el carácter de este personaje rasgos que la acercan a una filosofía de vida picaresca: "[ . . ] mujer precoz, de grandes y maliciosos ojos negros y una cara redonda llena de lunares y hoyuelos, hablaba mucho, voluble y locuaz [. . .]" (Las honradas 36). Graciela quedó huérfana desde pequeña, y luego más tarde, perdió a su hermano cuando éste se incorporó a la guerra. Su madre y ella quedaron en la miseria, así que no tuvieron otra alternativa que aprender a sobrevivir como pudieran. ${ }^{10}$ También, quizás debido a la situación económica de la familia, Graciela recibió una educación más liberal que sus amigas y esto la hace ver el mundo y la sociedad desde una perspectiva totalmente diferente.

Un rasgo de Graciela que Victoria señala es su aplomo para salir de situaciones difíciles. Este rasgo la sitúa dentro de la corriente picaresca, 
puesto que todo pícaro necesita de este aplomo para poder mentir y fingir cuando se encuentra en condiciones en que es necesario hacerlo. De la misma manera que le miente a la madre de Victoria cuando ésta le pregunta de qué están hablando, cuando son niñas aún; lo hace con Joaquín y todos los demás habitantes de la casa cuando cura a Victoria de la infección que le ha producido el aborto. Graciela es, a través de toda la novela, maestra en el arte del disimulo y la mentira.

A pesar de esto, el personaje es mucho más auténtico en su personalidad. Graciela es el ejemplo del pícaro que tiene que amoldarse y adaptarse, que tiene que engañar y burlar las convenciones sociales para poder medrar, pero en ella no hay dobleces, ni problemas de conciencia. No hay en ella falsos complejos de honradez y respetabilidad. Dentro de su "picarismo", hay honestidad, porque se mantiene fiel a sus principios.

Otro rasgo de la pícara que posee Graciela es su coquetería, acompañado de su carácter proteico, según lo señala Victoria: "[. . .] su coquetería inagotable se plegaba fácilmente al grave papel que las circunstancias le imponían, y sacaba partido de la seriedad y la tristeza, como antes lo sacaba del aturdimiento y la alegría" (Las honradas 52).

Una vez convertida en mujer, Graciela desarrolla una sabiduría profunda, debido a las experiencias vividas durante la guerra. Demostraba un gran conocimiento de la realidad de la vida, y, sobre todo, de los hombres. Por comentarios que les hace a sus amigas, se ve 
que no es ella una joven criada para ser esposa sumisa y fiel, sino la mujer que sabe lo que quiere y que se siente capaz de dominar al hombre. Se burla de los piropos de los hombres que la cortejan y se compadece de lo vanidosos y creídos que son algunos de ellos. A diferencia de Victoria y Alicia, que fueron novias "tradicionales" de visitas programadas y horas de sentarse en mecedoras, el compromiso de Graciela y Pedro Arturo estaba fuera de toda convención social. Esta relación está basada en el respeto mutuo, en los intereses comunes y en la confianza. Curiosamente, son ellos los únicos, a través de toda la narración, que dan la impresión de ser felices, de vivir en armonía y comprensión.

Graciela, ayudada por su personalidad proteica, juega con éxito el juego que le impone la sociedad. Se casa, pero a su manera, no solamente por amor, sino por interés y para subir en la escala social. A los ojos de la sociedad es una señora respetable, "una honrada"; pero en la intimidad se burla de las convenciones sociales que obligan a hombres y mujeres al matrimonio como único medio de convivencia legal y moral, y aclara la naturaleza del suyo: "¡Somos concubinos! Nos casamos para que las gentes no nos fastidiaran con sus escrúpulos. [. . .] Y convinimos en que si nos aburríamos uno o el otro, cada uno tomaba por su lado, y santas pascuas" (Las honradas 100). 
A pesar de su felicidad matrimonial, hay en el pasado de Graciela pasajes escondidos que reflejan su actitud picaresca en cuanto al comportamiento sexual. Se murmura que antes de casarse tuvo relaciones con varios hombres, quizás por la necesidad económica en que se encontraban ella y su madre. Ella misma le confiesa a Victoria algo de eso, cuando trata de convencerla para que calle y continúe su relación con Joaquín a pesar de las faltas cometidas: "Yo también he querido, odiado y sufrido mucho... hace años cuando casi una niña" (Las honradas 395). Graciela es el personaje femenino más equilibrado de la obra. Ella sabe que tiene que cumplir con el orden establecido, pero dentro de este orden, se mantiene siempre auténtica, libre de falsos pudores, y solamente así logra llegar a la cumbre: la felicidad que proporciona un amor verdadero y satisfecho.

Otro personaje femenino cuyo carácter entronca con la tradición picaresca es Georgina, una de las cuñadas de Victoria. Georgina proviene de un hogar que se ha visto plagado por las necesidades económicas y de una familia que la madre de Victoria califica como "¡ Una familia de alacranes [. . .]!" (Las honradas 190).

Al hablar de ella por primera vez en su confesión, Victoria comenta que le pareció que Georgina "[. . .] ocultaba picardías bajo la fingida modestia de sus grandes ojos pardos" (Las honradas 179). Y también señala "[. . . ] la vivacidad de sus ademanes y sus gracias de coqueta (que) 
atraían hacia ella las miradas de los hombres" (Las honradas 179). A esto hay que añadir la sabiduría y el conocimiento que posee la joven, aun de soltera, sobre el amor y el sexo, según el comentario de Graciela: "--No puedes imaginarte lo bien instruida que está tu cuñadita. Te aseguro que sabe más que tú, y quizás que yo de ciertas cosas... Se ha franqueado conmigo y puedes estar convencida de que es una alhaja [. . .]" (Las honradas 183).

Durante el tiempo que Georgina convive con su hermano y su cuñada en el ingenio, se revela aún más su filosofía de vida de índole picaresca. Hace numerosas amistades con la gente del ingenio y se entera de todos los chismes que circulaban en el lugar. Victoria comenta que al principio, aunque quería contarle las historias que iba averiguando, lo hacía "[. . .] en forma embozada, deseosa de seguir representando [. . .] la comedia del candor, mientras no estuviese segura [. . .]" de cómo pensaba ella (Las honradas 211 ). Sin embargo, poco a poco, se va abriendo y va demostrando su verdadera personalidad, hasta descubrirle a Victoria sus ideas con respecto a un tipo de hombre que ella juzga incapaz de inspirar verdadero amor en una mujer, y entre los que incluye a su propio hermano. De esta manera, ella siembra la duda en Victoria con respecto a su relación con el marido, y a la vez revela su filosofía del amor. 
Como toda pícara, Georgina busca un medio de acomodarse en la sociedad, burlando las convenciones de la misma. Al poco tiempo de instalarse en el ingenio, establece una relación amorosa poco convencional pero de gran conveniencia para ella. El enamorado es el sobrino del presidente de la compañía dueña del ingenio, y Georgina interesada como está en subir en la escala social, no quiere asustarlo con formalidades, más bien acepta una situación poco respetable para ella, y le permite ciertas libertades inaceptables como patrón femenino de conducta. Cuando Victoria descubre lo que ocurre y le advierte que el hombre lo que quiere es burlarse de ella, Georgina muestra una vez más su sabiduría de joven picaresca que sabe llevar el juego a su favor: "A eso viene él sin duda: a divertirse. Pero una cosa piensa el caballo y otra el jinete... Para llegar conmigo a la diversión que él pretende, es preciso antes pasar por la sacristía [. . .]" (Las honradas 227). Se observa pues, que Georgina lo que hace en realidad es utilizar el poder del cuerpo para atraer al hombre que puede ubicarla en un nivel más alto.

El carácter proteico de los pícaros aparece también en la personalidad de Georgina. Después de haberse manifestado como una joven alocada, coqueta y provocadora, ante el hombre que pretende conquistar, --propuesta del juego erótico--,cuando cree que ya lo cuenta como su víctima, adopta una pose totalmente opuesta. Después de la ausencia temporal del hombre, "[. . .] la joven afectaba [. . .] una modestia 
y un recato extraordinario, y era él quien tenía que perseguirla encarnizadamente, para conseguir que consintiera hablarle unos segundos" (Las honradas 241). Frente al hecho de tener que abandonar definitivamente el lugar donde se encuentra su enamorado, Georgina despliega, una vez más sus rasgos picarescos. Expresa su filosofía claramente: "Si es de ley irá donde yo esté; y si no lo es, ¿para qué quieres que me sirva ese posma?" (Las honradas 246).

La filiación picaresca de Georgina se hace más evidente en la comparación que establece Victoria entre ella y Graciela, después de haber convivido con la primera durante más de un año:

Georgina [. . .] calculadora, fría y egoísta, no se hubiera dado sin sólidas garantías [. . .]. Su belleza, su juventud y sus gracias eran valores que tenían de antemano señalado el precio. Se acicalaba cuidadosa y delicadamente, concretándose al exterior, lo mismo que una gata alisa su pelo, y tenía todos los mimos complacientes de estos animalitos cuando deseaba agradar. Pero también, como las gatas, escondía uñas afiladas en estuches de terciopelo [. . .]. (Las honradas 246-247)

A través del personaje de Georgina, el autor ratifica el mensaje que ya se advirtiera con Graciela: la carencia de valores éticos no es óbice para ascender en la escala social. 
Entre los personajes masculinos que aparecen en Las honradas uno de los que presenta rasgos picarescos más acusados es Fernando Sánchez del Arco. La personalidad de Fernando se perfila, desde el principio con rasgos donjuanescos, y no cabe duda que ambas filosofías, la del pícaro y la del burlador, tienen muchos elementos en común."

Si por su categoría social y por su apariencia de hombre de mundo Fernando no encaja en el prototipo del pícaro clásico, la conducta que sostiene a través de toda la relación con Victoria demuestra que el personaje posee una serie de rasgos que son típicos de una filosofía de vida picaresca. Es importante resaltar, que esta visión se ajusta y adapta a circunstancias específicas de cada personaje, o sea, que aunque el comportamiento pueda aparecer a los ojos del lector como divergentes de la psicología picaresca, en realidad la naturaleza intrínseca del personaje participa de esa filiación debido a las características de su propia personalidad.

De esta manera vemos que el personaje de Fernando, que a primera vista parecería alejado de la figura del pícaro, resulta, después de analizar con detenimiento cada una de sus acciones y los móviles que lo llevan a realizar esas acciones, tan pícaro como cualquiera de los del Siglo de Oro, solamente que en él la condición picaresca va encubierta con la apariencia de hombre respetable. 
La base de todo el comportamiento picaresco de Fernando se relaciona con el elemento sexual. Fernando acepta las leyes establecidas en cuanto al sexo dentro de los parámetros de la sociedad donde se desenvuelve. Él, como la mayoría de los personajes de Las honradas, es el producto de un código social que brinda al hombre una serie de libertades con respecto a su papel en las relaciones sexuales. Fernando se proyecta desde el principio como un seductor, "[. . .] a pesar de la corrección impecable de su máscara de sociedad" (Las honradas 284). Desde que ve a Victoria decide convertirla en su próxima presa, pero sabe que es una mujer decente y para hacerla caer tiene que recurrir a un arsenal de recursos de perfil picaresco.

Lo primero que hace es aparentar preocupación por sus empleados y dar la impresión de que es un hombre consciente de sus necesidades. Le hace patente a Victoria su intención de hacer todo lo posible porque ésta pueda reunirse con su esposo a la mayor brevedad posible y se presenta como un ser sensible que entiende las necesidades emocionales de los demás: "No me perdonaría jamás no haber contribuido a reunir a dos esposos que se quieren, pudiendo hacerlo" (Las honradas 287), cuando su propósito es mantener a la pareja alejada y así facilitar la consecución de su objetivo.

Fernando Sánchez del Arco representa su papel de amo benevolente y generoso a la vez que asume el de amigo. Se percata que 
Victoria no es sagaz y usa el subterfugio de una amistad antigua con la familia de ella para declararse su amigo. En aras de esta amistad, podrá irse acercando a ella, manipularla, seducirla, sin que se le pueda señalar ninguna acción reprochable. Aun en acciones de aparente insignificancia, Fernando despliega su psicología picaresca. Al marcharse Victoria, pone a su disposición un carruaje para que la lleve a donde ella quiera. Con esta acción amable logrará descubrir la dirección de Victoria. Y casi inocentemente, la previene de su visita: "--Tal vez tenga que contestar el informe de su esposo, por el mismo conducto. En ese caso no será necesario que se moleste: iré yo personalmente a su casa" (Las honradas 290).

Con esta escena queda planteado el juego del seductor. A partir de este momento todas y cada una de las acciones de Fernando están en función de someter a Victoria. Como todo pícaro, entiende que hay una sociedad que lo obliga a cierto comportamiento, que puede obstaculizar el éxito de su empresa, pero en lugar de luchar abiertamente, la burla. Una de las acciones más picarescas de Fernando es la treta que usa para conseguir un lugar seguro y discreto donde citarse con Victoria. El seductor se vale de una alcahueta, a quien instala en la casa vecina a Victoria.

Una vez ha logrado su objetivo--Victoria es ya su amante-Fernando muestra otras características de índole picaresca. En primer 
lugar, en un acto de falso honor rehúsa a llevarse a Victoria con él, porque no "[. . . ] sería capaz de arrostrar el escándalo de raptar a la esposa de un empleado mío" (Las honradas 363). Además hace despliegue de un acendrado pragmatismo al enfrentar la situación del embarazo de la joven. Cuando se entera, simplemente replica: "--Ésa es una complicación grave y tonta, a la que habrá que buscar remedio enseguida" (Las honradas 342). Luego busca el remedio que más le conviene para evadir la responsabilidad y el escándalo, mientras conserva a la mujer: el aborto. Fernando se muestra como un personaje antiheroico, carente de principios morales, para quien el fin justifica todos los medios. Con este personaje, Carrión ejemplifica una tipología cubana producto de una educación que inculca la superioridad del discurso social masculino.

Un análisis de los personajes de Las honradas desde una perspectiva de la picaresca, nos lleva a la conclusión de que en la mayoría de los mismos, el comportamiento picaresco está en función de la satisfacción de la sexualidad. A pesar de su título, la obra resalta la idea de que para ser verdaderamente feliz, la mujer no puede mantenerse en el grupo de "las honradas", tal y como se entiende el término dentro del contexto de la novela. Las únicas tres mujeres que llegaron a ser verdaderamente felices en sus relaciones de pareja, en algún momento de sus vidas hicieron una incursión en el mundo de "las impuras". 


\section{Las impuras.}

Con la novela Las impuras se completa el díptico novelístico de Miguel de Carrión, cuyo tema principal es el de las relaciones sexuales y la condición de la mujer en dicho contexto. Esta segunda novela, continuación de Las honradas, reproduce el mismo fenómeno que la primera, pero situada en un ambiente de clase baja. En ella el autor "[. . .] esboza un cuadro de la vida galante habanera en su tercer lustro de existencia republicana [. . .]" (Pogolotti 57), y "narra la vida prostibularia de la urbe semicolonial: el ambiente de casas de rango [. . . ], y la atmósfera crapulosa de las callejuelas baratas [. . .]" (Alvarez 18), donde se desenvuelven una amplia gama de personajes de vida picaresca, "[. . .] desde los estudiantes e hijos de terratenientes hasta los vástagos de los senadores y representantes, pasando por los comerciantes de todo pelaje, los asalariados y los elementos profesionales, los sádicos y los embrutecidos" (Alvarez 19).

Eduardo Heras considera que Las impuras es "una de las más importantes novelas cubanas de la primera mitad del siglo" (18), y concluye que ésta es "además invalorable documento sociológico para el estudio de una época [. . . ] que Carrión ataca y critica con feroz ironía, insertándose de esta manera en la larga tradición de denuncia de la novelística cubana [. . .]" que se inicia desde mediados del siglo XIX. (18) 
Como acertadamente comenta Juan J. Remos, en Las impuras Carrión hace

[. . . una pintura magistral de la vida desordenada y abominable de esas desventuradas, muchas veces verdaderas incomprendidas, como la protagonista, que no alcanzan más refugio que el lupanar inmundo, donde se corrompe la conciencia y se rompen las amarras del pudor, y a donde siempre llegan aquéllas tras una historia de burla y de escarnio de sus ilusiones [. . .]. (Historia 3: 296-297)

Como parte de esta pintura el autor presenta una variedad de personajes que, por desenvolverse en el mundo del hampa y la corrupción, se insertan en lo que podía denominarse la "tradición picaresca criolla".

Dentro de la tipología que presenta esta novela abundan los personajes que actúan y se desenvuelven en la sociedad de acuerdo con la filosofía del pícaro. Solamente resalta como excepción el personaje de Teresa Trebijo, la protagonista que, si bien al principio da la impresión de comportarse picarescamente, termina demostrando ser quien tiene más altos valores morales, y quien, debido a esto, se convierte en víctima del orden social.

Teresa Trebijo es el personaje a quien en Las honradas se alude como la hermana "perdida" de José Ignacio Trebijo, el marido de Alicia. Es una mujer que contrariamente a la "honrada" Victoria, y a pesar de que 
pertenece "[. . .] a una de las más distinguidas familias de la época colonial [. . . ]" (Las impuras 43), reniega de su educación y de su clase, para convertirse en la amante de un hombre casado.

Anteriormente a este hecho hay en la obra indicios que llevan al lector a pensar que Teresa se mueve por los caminos de la picaresca. Primero, el autor describe al personaje como "[. . .] coqueta por temperamento [. . .]" y de un "[. . .] cuerpo lleno de encantadoras promesas [. . .]" (Las impuras 46), características éstas frecuentemente halladas en el tipo de la pícara. Luego detalla la amistad que une a la joven Teresa con la viuda de Riscoso, mujer que

[. . .] había vivido muchos años sometida a la tiranía de un marido viejo y despótico, que tardó demasiado en morirse, y al recobrar su libertad, tenía, ella también, sed de placeres, de aire libre y de ruidosas expansiones. Por eso hablaba con tanto horror de los amantes como de los maridos, prefiriendo el flirt y los pasatiempos ligeros y arrullando los oídos de la vehemente Teresa con las máximas de una filosofía alegre y despreocupada. (Las impuras 51 )

Es de imaginar que esta amistad con la viuda sería la iniciación de Teresa a la filosofía picaresca, dentro de una "[. . .] moral nueva, desenvuelta, atrevida [. . . ]" (Las impuras 51). Según se solidifica la amistad entre 
Teresa y la viuda, se evidencia aún más el carácter picaresco del comportamiento de ambas:

La viuda [. . . inició a Teresa en una parte de los secretos de su vida. Ella y otras que pensaban del mismo modo habían formado un pequeño círculo de vividores discretos, que se reunían en días previamente escogidos, con todas las prácticas de una sociedad secreta. Su objetivo era divertirse un poco, sin comprometerse mucho, y los miembros eran admitidos después de un riguroso examen. (Las impuras $52)^{12}$

Es precisamente en esta especie de sociedad secreta donde conoce Teresa al que más tarde se convirtió en su amante: Rogelio Díaz. A partir de este momento se manifiesta en la personalidad de Teresa una serie de rasgos de perfil picaresco. Comienza disimulando la relación, puesto que sabe que la viuda no la aprueba. Luego, le miente a su niñera y le dice que ya se entregó a Rogelio para que le permita verlo en su casa, y finge llorar para convencerla. Por último, como todo ruego ha sido en vano, y demostrando su sentido pragmático, "Teresa inventó una serie de mentiras, y acabó asegurando muy formalmente que antes de seis meses estaría casada [. . .]" (Las impuras 58), para poder vencer los escrúpulos de Dominga. 
A pesar de todo esto, una vez convertida en querida de Rogelio y expulsada de su casa por su propio hermano, la conducta de Teresa sufre una metamorfosis que la sitúa fuera de la tradición picaresca. Al marcharse de la casa de sus padres definitivamente, en una demostración de orgullo y dignidad, no se lleva ningún artículo de valor; ni siquiera sus propias joyas. A pesar del amor que siente por Rogelio y de la necesidad económica en que se encuentran ella y sus dos hijos, nunca accede a los ruegos del amante de que reclame el patrimonio que heredó de su familia y que se halla en manos de José Ignacio. El orgullo de Teresa es más fuerte que el deseo de llevar una vida muelle.

Esa actitud recta de Teresa continúa a través de toda la obra, y se manifiesta de manera evidente en la forma en que enfrenta la relación con Rogelio. Teresa se propone impedir que Rogelio abandone definitivamente a su esposa y a su hija, y mientras es su querida lo consigue, demostrando con este comportamiento su falta de egoísmo y su capacidad de sacrificio. Por otra parte, se muestra como una persona sincera, que no admite dobleces ni fingimientos y así se lo hace saber a Rogelio desde el principio:

En lo único que deseo que nuestro cariño se diferencie de los demás es en que creo que debemos decirnos mutuamente todo lo que sintamos, hasta el deseo de separarnos, si algún 
día llegamos a ese extremo. Con las mujeres que piensan como yo no es preciso ser hipócritas... (Las impuras 64)

Otro aspecto de la personalidad de Teresa que la aparta de la filosofía picaresca, y la convierte en una "impura-honrada" es su fidelidad al amante y su recato y decencia, aun cuando se ve forzada a vivir en un cuarto en un edificio habitado por gente de la peor calaña. Aunque la disgusta el ambiente donde vive, cree que "no se contagia moralmente más que la que quiere contagiarse" (Las impuras 119). Aunque viva rodeada de gente de vida picaresca, ella no es y no será una de ellos.

El orgullo de Teresa, su dignidad, su fidelidad a un amante que no la valora y su solidaridad con la otra familia de Rogelio, la llevan finalmente a prostituirse. Sin embargo, en esta acción hay un elemento positivo: se prostituye por altruismo, por conseguir dinero para costear el último recurso que podría salvar la vida a la hija de Rogelio.

Con el personaje de Teresa Trebijo Carrión demuestra cuán equivocada estaba la sociedad de su época cuando se trataba de juzgar el honor y la respetabilidad de la mujer. Su sentido del deber y su espíritu de sacrificio la llevan a aceptar las más terribles condiciones de vida sin caer en la marginalidad, en la vida pícara. Sin embargo, el autor es pesimista: ese espíritu noble, puro, termina siendo víctima de una sociedad que la obliga a prostituirse. 
En contraposición a Teresa Trebijo, y como rival de ésta, aparece en Las impuras Carmela La Aviadora, a quien el autor dedica un capítulo completo de la novela. Este personaje se perfila desde su presentación como descendiente de las pícaras barrocas. Carmela, después de casarse, tuvo una experiencia que la inicia en la vida picaresca:

La sedujo un primo de su marido, [. . .] que la incitó luego a fugarse del hogar y reunirse con él en La Habana [. . . . El amante estimuló todos sus deseos de placeres y de lujo, y la dirigió en sus primeros pasos por el camino del vicio, ayudándola a gastar el dinero ganado. Cuando se recibió de doctor, contrajo matrimonio con una joven rica y la dejó plantada en la mitad del arroyo. Carmela sólo tuvo que agradecerle [. . .] la refinada educación que le diera en pocos meses, preparándola para ejercer sabiamente su nueva profesión. (Las impuras 145-146)

De esta manera, entra de lleno en la vida picaresca.

La primera característica que se destaca en Carmela es su belleza corporal y su sensibilidad:

Estaba medio desnuda en el lecho, cubierta apenas, con una camisa que no le llegaba a las rodillas y por cuyos numerosos calados asomaba la carne. Sus lindas piernas, un poco gruesas, pero torneadas y finas en los tobillos, 
aparecían completamente descubiertas, cruzadas una sobre la otra y calzadas con medias negras y ligas azules, como si hubiese estado preparada para una exhibición. (Las impuras 140)

Carmela se dedica a la prostitución, poniéndole un alto precio a su cuerpo, pero no tiene amos, no vive en un prostíbulo. Es dueña de su propia casa, posee un auto y tiene una criada y numerosos servidores. Según Carrión, "pertenecía [. . .] a la aristocracia del hetairismo habanero, y se le tributaban homenajes y envidias por las infelices que no habían podido llegar a tal altura" (Las impuras 147).

A pesar de que La Aviadora se sirve de un grupo selecto de clientes para poder mantenerse en una buena posición económica, hace todo lo que puede por conquistar a Rogelio con quien se ha encaprichado. Para lograrlo pone en práctica todos sus recursos picarescos: el primero, vigilar todos los movimientos de Teresa; luego, manipular a Rogelio que comienza a perder las esperanzas de que Teresa reclame su herencia. La Aviadora se da cuenta de que Rogelio es débil de carácter y lo amenaza constantemente con no tratarlo más si no accede a todo lo que ella quiere. La dinámica de la relación cambia después del primer encuentro amoroso de Rogelio y La Aviadora. Ella confiesa sentirse defraudada por las capacidades amatorias del hombre y afirma: "Si me decido a seguir adelante el juego, no es sino por quitárselo a esa pretenciosa" (Las 
impuras 145). Una vez más demuestra el personaje un rasgo de su carácter picaresco: la crueldad.

La mentira es otro de los recursos de La Aviadora para poder sobrevivir en el mundo en que se desenvuelve. A pesar de que está sutilmente sugerido, el personaje sostiene una relación homoerótica con una tal Margot, mujer celosa y peligrosa. Para mantenerla tranquila y de su parte, Carmela le miente descaradamente. Estando en compañía de Anita, le dice por teléfono: "¿Que si estoy sola ahora? Sí, sola, santona, solita. ¿Y tú...? ¡No, no, no! ¡Te lo juro por los huesos de mi madre! ¡No te engaño!" (Las impuras 149).

Las acciones de Carmela están guiadas hacia la obtención de dos objetivos: el bienestar económico y la satisfacción de su capricho amoroso. Carmela usa a todos los seres que la adulan y la respetan, y se vale de la mentira, el subterfugio y la trampa para conseguir lo que quiere. A diferencia de Teresa, logra lo que quiere: llevarse a Rogelio. Entre los personajes masculinos de Las impuras, destacan por su carácter picaresco Rogelio, Paco y Rigoletto. Rogelio representa al pícaro que aun perteneciendo a una familia de posición económica desahogada, utiliza todo tipo de tretas, trampas y engaños para llevar una vida de parásito y vividor. Advierte Carrión que el joven "no tenía ni seriedad ni constancia. Había sido sucesivamente estudiante de derecho, de medicina y de agronomía, para declararle luego a su padre que su verdadera 
vocación consistía en ser militar" (Las impuras 55). Se perfila como malcriado, inconsciente, irresponsable. Muy joven se involucra sentimentalmente con una muchacha enfermiza y de baja clase social, con quien tiene una hija. Termina casándose con ella porque su propia madre lo obliga.

Al encapricharse con Teresa, el comportamiento de Rogelio está todavía más en consonancia con la filosofía de vida picaresca. Se presenta ante la joven como un hombre emprendedor que quiere iniciar un negocio que lo haría millonario. Tomando esos supuestos negocios como pretexto, le saca dinero a su madre y se escapa con Teresa a los Estados Unidos. A base de numerosos engaños extiende el "viaje de negocios" hasta que la madre está casi arruinada.

De regreso en Cuba, continúa la trayectoria picaresca del personaje. Su carácter acomodaticio y pragmático lo lleva a aceptar la situación de tener una doble vida, dejándose querer por sus dos familias, sin preocuparse de buscar la manera de ganar el dinero necesario para su propia subsistencia y la de ambas familias. Vive una vida de indolencia y pereza: "[. . . ] montaba excelentes caballos, criaba perros de caza y gallos de pelea, se tumbaba a dormir largas horas en una hamaca, bajo el cobertizo de su casa de campo, y tenía abandonado el cultivo a pequeños colonos y empleados que le robaban" (Las impuras 66). 
También señala el autor cierta veta proteica en el carácter de Rogelio al comentar: "[. . .] continuó luciendo sus flamantes polainas de cuero amarillo, cuando se disfrazaba de campesino, y sus elegantes trajes de población, las veces que se cansaba de representar consigo mismo esta comedia" (Las impuras 67), ${ }^{13}$ a la vez que advierte en él el comportamiento del personaje que se aprovecha de los defectos de la sociedad en la que se desenvuelve para lograr sus propósitos cuando dice: "se dispuso a emprender su gran obra política, con la esperanza de recuperar en poco tiempo cuanto había perdido" (Las impuras 68).

Al igual que otros pícaros, Rogelio es un ser internamente inestable y cambiante, y esto se demuestra en el campo de las relaciones amorosas. La relación de Rogelio con Teresa carece de toda estabilidad. A pesar de que a veces da la impresión de que están unidos por amor, la actitud del hombre lleva al lector a pensar lo contrario. Más bien, y casi de forma constante, puede inferirse que lo único que mantiene a Rogelio cerca de Teresa es la esperanza de que ella reclame su fortuna y poder disfrutar de ella. Todos sus códigos expresivos están encaminados a lograr este propósito, y cuando advierte que nunca lo logrará, comienza a engañarla con La Aviadora, que representa una alternativa para su afán de medro.

Por su parte, el personaje de Paco ejemplifica al típico vividor, al pícaro que ya ha conseguido un puesto en la escala social valiéndose de 
todos los ardides de la filosofía picaresca. Cuando este personaje se presenta en la obra, es ya

[. . . el secretario de un político influyente [. . .]. Gastaba dinero sin contarlo, se proclamaba a sí mismo árbitro de la galantería y de la elegancia, se le veía casi siempre en compañía de su ilustre jefe, y como tenía audacia y aplomo y hablaba de todo en voz muy alta se le recibía en todas partes con grandes agasajos. [. . .] Paco subía como la espuma, se vestía como un millonario y se hacía desear por las impuras, a quienes hacía alarde de despreciar públicamente, con groserías y brutalidades de antiguo chulo. (Las impuras 95) A pesar de todo lo que ya había logrado, "[. . .] quería encontrar una mujer rica para casarse [. . .]", y así subir aún más en la escala social (Las impuras 100).

Sin embargo, se sabe que el personaje proviene de una clase baja y que tuvo una vida de pobreza y miseria, por los comentarios que hace Carmela quien, refiriéndose a Paco, afirma: "Lo cierto es que le maté mucho el hambre y que cuando lo conocí no tenía ni calzoncillos que ponerse" (Las impuras 153). De esta manera, Carrión demuestra a sus lectores, como en los primeros años de República existían en la sociedad tipos que, teniendo un origen humilde y mísero, llegaron a enriquecerse y a convertirse en personajes importantes siguiendo una conducta 
marginal y adoptando una idiosincrasia de perfil picaresco, que los relaciona claramente con los pícaros del Siglo de Oro.

Por último, Rigoletto es un personaje de perfil híbrido entre el pícaro y el gracioso, aunque si bien es cierto que el último presenta, generalmente, rasgos en común con el primero. ${ }^{14} \mathrm{~A}$ nuestro juicio, es de los personajes que presenta Miguel de Carrión, el que mejor entronca con la tradición picaresca española iniciada con Lazarillo de Tormes.

En el capítulo titulado "El corazón de Rigoletto", se presenta al personaje desde una perspectiva que lo saca del ámbito de la corrupción política y social en el que se desenvuelve, para descubrirnos su sensibilidad frente a la realidad del personaje. En este capítulo, Rigoletto se quita el disfraz de pícaro ante Teresa y le confía sus secretos. Las semejanzas con el pícaro tradicional son innegables:

[. . .] vivía con su abuela, anciana señora de cerca de noventa años, siempre achacosa, con quien gastaba cuanto dinero podía conseguir. Se llamaba Emilio, sin otro apellido, pues su padre lo había tenido con una corista del teatro Cervantes, a quien se lo quitó más tarde para llevárselo al hogar materno y confiarlo a los cuidados de la buena anciana, que había sido su único sostén en la infancia. A los tres años el mal de Pott desatendido lo dejó contrahecho para el resto de su vida. Su padre emigró a Brasil, de donde mandó dinero al 
principio, y murió algún tiempo después en la pampa

argentina. Él, Rigoletto, había aprendido a ser desvergonzado

e insolente en la dura escuela de la vida. (Las impuras 219)

Por esta confesión nos damos cuenta de que él, al igual que Lázaro, no tuvo otro remedio que convertirse en pícaro. Aún así le quedan sentimientos puros y se los ofrece a quien considera digna de ellos, a Teresa, como hizo Lázaro con el escudero.

Rigoletto es quizás el más proteico de los personajes picarescos de Carrión. Al principio se presenta como un "[. . .] parásito eterno, famoso muñidor electoral, hilvanador admirable de despropósitos, comensal de todas las mesas donde reinase la alegría y amigo sincero de todas las pecadoras a quienes hacía reír o consolaba en sus pequeñas penas, haciéndose pagar con besos sus chistes y sus delicadas ternezas [. . .]" (Las impuras 126).

Sin embargo, como bien señala Eduardo Heras "[. . .] tiene nombre de payaso [. . . ] y lo es como todo payaso, sale a la escena para hacer reír, a ser motivo de burla, a hacer travesuras, aunque por dentro [. . .] sea capaz de sentir el amor como un ser humano corriente [. . .]" (17). Así es Rigoletto un personaje picaresco por su origen, por su forma de comportamiento social marginal, por su eminente carácter proteico que lo lleva a adoptar, casi forzosamente por su defecto físico, el papel de payaso. En consonancia con el payaso que esconde bajo una máscara sus 
verdaderos sentimientos también está un rasgo del pícaro renacentista, que a pesar de su forma de vida picaresca conserva rasgos nobles para con los desafortunados.

\section{Conclusión.}

Al realizar una lectura picaresca de la tipología presente en el díptico narrativo de Miguel de Carrión se llega a la conclusión de que muchos de sus personajes, tanto femeninos como masculinos, y pertenecientes a las más variadas clases sociales, participan en un comportamiento de índole picaresca. En algunos de ellos, como en Victoria, de Las honradas, el proceso es gradual y casi inconsciente; en otros como en Rigoletto, es producto de circunstancias de nacimiento y vida; en otros es el recurso que utilizan para lograr un objetivo en la vida, como en el caso de Graciela, Georgina o Paco. La mayoría de los personajes que siguen una filosofía de vida picaresca logran conseguir su meta; sin embargo, aquéllos que mantienen una línea de conducta recta y se mantienen fieles a sus principios, generalmente fracasan. De este último el caso más evidente es Teresa, de Las impuras. Con esto se evidencia, de manera definitiva, el pesimismo de Carrión, que lleva al lector a inferir que en la Cuba de principios del siglo XX solamente se conseguía el éxito con una conducta marginal, opuesta a los cánones de la decencia y la honradez. Es interesante destacar que a diferencia de los 
pícaros renacentistas y barrocos, cuyo objetivo principal es el "medro" desde el punto de vista económico y social, en las novelas de Carrión el objetivo a conseguir está casi permanentemente relacionado con el amor y el sexo.

Por último, hay que agregar que según la visión que se percibe en las novelas estudiadas, Carrión señala como causante principal del comportamiento picaresco de los individuos a la educación que con respecto a las relaciones entre los sexos se les daba a éstos. Este hecho se observa más claramente en Las honradas, con el personaje de Victoria, a quien su visión distorsionada de las relaciones sexuales y del papel de la mujer dentro de estas relaciones le hace caer en el adulterio, $y$, paradójicamente, es solamente después de este episodio que establece una fructífera relación con su pareja. En el caso de Las impuras, aunque de forma velada, también se observa esta idea, cuando el autor enjuicia la moral sexual de algunos de los personajes; sin embargo, se evidencia también ampliamente la influencia que ejercen la corrupción política y social en el individuo que busca subir de categoría utilizando cauces no convencionales, es decir, siguiendo un proceder picaresco. 
Notas

' Esta novela quedó inconclusa y fue publicada póstumamente con prólogo de Mario Parajón. Según la fecha que aparece en el manuscrito, debe haber sido escrita alrededor de 1919.

${ }^{2}$ Esta cita aparece en el artículo titulado "Aproximaciones críticas a Miguel de Carrión" de Salvador Bueno, publicado en Cuba en la Unesco, y proviene de una carta de Enrique José Varona que publicó la revista EI Fígaro de la Habana en 1917.

${ }^{3}$ Mirza González afirma que "en la producción literaria de Carrión se observan tres categorías de individuos: los principales, que interesan esencialmente por su evolución psicológica; los personajes 'conciencia' cuya función va a ser la de maestros, consejeros o perturbadores de la personalidad mental del protagonista y son los más próximos a él; y los personajes 'masas' o ambientales que representan a un tipo genérico de la sociedad, los cuales el autor utiliza para hacer destacar más un vicio social, y contribuyen con su presencia a dar una pintura más real, exacta y vívida del medio ambiente" (La novela 50).

${ }^{4}$ También estos personajes son, a veces personajes "conciencia", e influyen directamente a otros personajes en el proceso de convertirse en pícaros, mientras burlan el orden de la moralidad sexual establecida.

${ }^{5}$ Según Arturo Montori, el tema favorito de las novelas de Carrión es "la caída de la mujer" (La obra literaria 345).

${ }^{6}$ Como las novelas picarescas, Las honradas puede considerarse como Bildungsroman, puesto que es a través de las diferentes experiencias vividas que Victoria aprende lo que es la vida, y son estas mismas experiencias las que la hacen cambiar su forma de ser y de pensar. También la propia protagonista considera su experiencia vital como un viaje que divide en tres jornadas. De la misma manera, es interesante notar que la vida de Victoria, como la de los pícaros, sigue una trayectoria itinerante.

7 Este momento es comparable a la pérdida de la inocencia de Lazarillo cuando el ciego le da el golpe contra el toro en Salamanca.

${ }^{8}$ Al principio de la narración Victoria comenta "[...] he tenido la manía de saberlo todo, de querer explicarme el porqué y el cómo de cada cosa, de 
no aceptar como verdad nada que no me pareciera explicable" (Las honradas 31 ).

${ }^{9}$ La participación de Victoria y su hermana en "una hermandad", es un detalle que remite al lector al ambiente picaresco del Barroco, especialmente al de "Rinconete y Cortadillo".

10 Esta situación de la vida de Graciela, que la relaciona con los pícaros clásicos, es además una de las causas para que la muchacha desarrolle su ya quizás innata, condición picaresca.

1 Ambos tipos tienen como base de su comportamiento el fingimiento, el disimulo y la mentira; y ambos también hacen uso de su capacidad proteica para adecuar su comportamiento a cada una de las circunstancias que tienen que afrontar. El don Juan es, en la mayoría de los casos, un pícaro de alta categoría social, que no tiene como objetivo de su filosofía de vida la obtención de un puesto más alto en la sociedad, sino la satisfacción de su orgullo de conquistador.

12 Este grupo de vividores trae a la mente la hermandad a la que pertenecían Rinconete y Cortadillo.

${ }_{13}$ No debemos olvidar que una de las características que se le señala al tipo del pícaro es el de ser un hombre de apariencias y disfraces, factor que contribuye a su conducta proteica. En este caso es significativo que el autor se refiera a la indumentaria de Rogelio como "disfraz", señalando así la falsedad de la situación y llevando al lector a inferir que todo esto no es otra cosa sino una representación, hecho éste que se refuerza al usar el término comedia para referirse a la misma.

${ }^{14}$ Hay que recordar que este personaje originado en el teatro del Siglo de Oro, es la contrafigura del galán y es por lo tanto de naturaleza antiheroica, cobarde, materialista, muchas veces. Ayuda a su amo a lograr objetivos, a veces de naturaleza poco respetable, mediante la burla o la trampa, como ocurre en El caballero de Olmedo. Estas características entroncan de modo definitivo con el pícaro. 
Capítulo Sexto. Personajes picarescos en la narrativa de Carlos Loveira.

Carlos Loveira y Chirino (1882-1928) está considerado por la crítica como "[. . . el el más fecundo de los novelistas sociales [. . .]" (Remos, Proceso histórico 268). A juicio de Salvador Bueno,

la producción novelesca de este escritor cubano representa un aporte de extraordinario valor para el conocimiento de nuestra sociedad republicana, un intento vigoroso de examinar la misma entraña de personajes cubanos sumidos en circunstancias muy propias de nuestro país, el afán de mostrar, a través de una técnica naturalista ya superada en su época, la interpretación de una Nación en trances de derrota, abatimiento y desengaño. (364)

El mismo escepticismo y sentimiento de frustración nacional que se observan en la mayoría de los escritores cubanos de esta época, se hacen presentes en la obra narrativa de Carlos Loveira. En este sentido, "la actitud de Loveira coincidiría en lo fundamental con los narradores del período, pero en él encontramos algunas peculiaridades específicas, como son el carácter picaresco de no pocos de sus personajes (y) sus ideas sociales [. . .]" (Alvarez 20).

Como muy bien ha señalado Berardo Valdés, en general, las novelas de Loveira "[. . . ] se caracterizan por plantear problemas de índole social en que expone su tesis personal, satirizando los tipos y 
costumbres cubanas; con propósito de emancipación ideológica, denuncia las injusticias económicas y sociales y la corrupción política" (39).

La obra narrativa de Loveira la constituyen, principalmente, cinco novelas: Los inmorales (1919), Generales y doctores (1920), Los ciegos (1923), La última lección (1924) y Juan Criollo (1928). Escribió unos relatos breves que se publicaron en revistas y periódicos de la época. Los inmorales es una novela donde se plantean conflictos de índole social, principalmente el tema del divorcio. En la misma se señala que en realidad los inmorales "no son los que se burlan de las leyes para oficiar en el altar del amor, sino los que ocultan sus deseos bajo el antifaz de la hipocresía [. . .]" (Remos, Proceso histórico 268). En su segunda novela, Generales y doctores, Loveira mezcla la novela histórica y la crítica social. La misma es un

animado [. . . ] cuadro de la vida colonial y de la manigua insurrecta, es una aguda sátira contra la tendencia de conceder prerrogativas a los que ostentan los grados que dan título a la novela, y que fue costumbre muy practicada en el ambiente cubano del primer cuarto de siglo. (Remos, Proceso histórico 268)

Salvador Bueno la caracteriza como "un cuadro sombrío, turbio, de los inicios de la República, con sus chanchullos políticos, con sus "generales 
y doctores" dispuestos a todas las componendas para lograr el poder político" (361). Los ciegos, por su parte,

[. . .] es un alegato contra el oscurantismo clerical y una proclamación amplia y sensata de las nuevas tendencias sociales, cada vez más avanzadas hacia la liberación individual y colectiva. El autor llama ciegos a los que no ven la verdad que invade al mundo, los que no comprenden el derrumbe de la tradición cuando es intransigente, demolida por la piqueta destructora del progreso que es milagrosamente constructiva a la vez. (Remos, Historia 3: 304-305)

Juan Criollo es, en opinión de Max Henríquez Ureña, " [. . . la más descarnadamente naturalista [. . .]" (2: 342) de las novelas de Loveira. Según la opinión de Marcelo Pogolotti, "su interés principal reside en el panorama de la vida colonial y de los primeros años de la República" (27). En ella, el autor "[. . .] extiende su mirada por todo el contorno social y político del país" (Bueno 363).

\section{Generales y doctores.}

En Generales y doctores, "Loveira recoge [. . .] la realidad cubana durante la primera generación republicana, representada principalmente por la lucha entre los veteranos de la guerra de 
independencia y los profesionales que se disputan entre sí el mando de la Isla" (Marqués 111-112). Es ésta "[. . .] la novela de esa vida pública, a la que es preciso ir con un título académico, que no se explota científicamente, o con un grado militar que sí se explota" (Gay Galbó 184).

La obra está narrada en primera persona por el protagonista, Ignacio García, "[. . .] que escribe su biografía íntimamente relacionada con el devenir histórico de Cuba entre 1875 y 1918" (Artalejo 101), y presenta una tipología representativa de dicha época en la que abundaban, según se percibe en la novela, los personajes de filiación picaresca. Estos personajes aparecen relacionados con el protagonista desde su niñez y continúan vinculados con él hasta la edad adulta. De esta manera, a través de Ignacio, que a nuestro juicio es como una especie de conciencia, Loveira desarrolla estos personajes que en su mayoría llegan a ser o generales o doctores.

En la primera parte de la novela, titulada "En días de tristeza y duda",

[. . . Ignacio descubre sus primeras vivencias y su adolescencia en Placeres y Matanzas, presentando un cuadro de las costumbres que caracterizan la vida cubana durante la colonia. Este cuadro está integrado por una amplia variedad 
de personalidades con quien Ignacio se tropieza a lo largo de esos años [...]. (Artalejo 102)

El ambiente propicio para la proliferación de personajes picarescos se percibe desde el comienzo de la narración que Ignacio sitúa en un momento anterior a su nacimiento, cuando su padre llega a la Isla:

En el año de 1875 hubo en La Habana una gran arribazón de sardinas gallegas; mote con el cual, en aquella época de hondos rencores entre criollos y "peninsulares", los primeros bautizaban a los segundos que, nuevos argonautas en las terceras de los trasatlánticos, cruzaban el charco inmenso para venir, en busca de fortuna, a la barraganía de burócratas corrompidos y factoría de mercaderes trashumantes que según el más frondoso de nuestros oradores revolucionarios, era la Gran Antilla Colonial, la siempre fiel Isla de Cuba. (Generales 3)

Entre estas "sardinas gallegas" Ilegan Manuel y Pepe García, padre y tío de Ignacio respectivamente. Ignacio establece inmediatamente las diferencias entre ambos: su padre, un hombre de bien que "[. . .] llevaba con dignidad su traje de americana [. . .] y al firmar ponía todo su nombre, Manuel de Jesús García y Pereira, en fina letra inglesa y sobre una rúbrica extensa, complicada y elegante" (Generales 4); su tío, que 
"[. . .] se conformaba con ser llamado 'Pepe' García, escasamente"

(Generales 4). Este Pepe García es uno de los personajes que más marcadamente manifiesta una filosofía de vida picaresca a través de toda la narración.

Uno de los rasgos picarescos que enseguida se hace patente en la personalidad de Pepe García es su afán de ascenso social: "[. . .] mi tío vino a América con el firmísimo designio de hacer dinero por todos los medios compatibles con la honradez al uso [. . .]" (Generales 25)'. Y, como señala Ignacio, su tío aprovechó muy bien el tiempo, "a los dos años de Cuba, 'Pepe', ascendido a 'Don Pepe', tenía su 'bodeguita', allá por el Matadero, barriada orillera de la ciudad de Matanzas, [ . . ]" (Generales 4). Éste sería solamente el primer paso en su escalada. Casi a los veinte años de su llegada a la Isla, tenía "además de su bodega-filón, media docena de casuchas de alquiler y una taleguita, allá por la calle del Río, por la Sucursal del Banco Español de la Isla de Cuba" (Generales 33). Ya en los inicios de la era republicana, lo encontramos convertido en el dueño del Ingenio Iberia y en "[. . .] un personaje de fama nacional, (en) el creso más poderoso de la República [. . .]" (Generales 201), cuyo solo nombre y presencia desencadenan reacciones que evidencian el poder y la fama de que goza el personaje entre las diferentes clases sociales:

[. . .] las señoras toman un aire atento y sonriente; los políticos de altura enmudecen y adquieren cortesana 
circunspección; el taco provinciano adopta una pose gravísima; los "gallegos" aburguesados se revuelven inquietos y abren tamaños ojos, y el obispo y su amigo el congresista liberal se ponen de pie, extendiendo sus manos al todopoderoso [. . . ]. (Cenerales 201)

Este fuerte deseo de ascender en la sociedad viene unido a otras características de corte picaresco. En primer lugar, para poder llegar donde llegó, don Pepe se vale de un arsenal de trampas, burlas y engaños, lo que demuestra su carencia de principios morales. Al referirse a su tío y al tipo de negocio que tenía, Ignacio se expresa con calificativos despectivos que hacen inferir al lector la despreciable categoría de ambos:

Mi tío era el prototipo de ese engendro adecuado de la Colonia factoría que se llama el bodeguero. Y prototipo de la bodega de la Colonia, que hoy subsiste en la República, aunque superficialmente modernizada y con ribetes de higiene americana, era la bodega de mi tío. [. . .] La bodega rastro, cantina, lugar de hamponesca tertulia, escuela de malacrianzas, fuente inagotable de los más negros fraudes alimenticios. (Generales 20)

Más adelante, al describir su trabajo, Ignacio hace referencia explícita a los manejos fraudulentos que realiza el personaje: "[. . .] realizaba yo el 
difícil y cotidiano trabajo de ordenar la asimétrica contabilidad que mi tío llevaba en sus libros, y él maquinaba con los resortes de aquella balanza de libras de trece onzas [...]" (Generales 21). A estas trampas que le facilitaba al personaje el comercio de la bodega, hay que añadir el intento frustrado de involucrarse en la fabricación de monedas falsas. Aunque en este suceso el pícaro termina sufriendo las burlas de otro personaje más pícaro que él, el modus operandi picaresco del personaje se manifiesta, una vez más, de manera evidente.

Don Pepe García exhibe también, como parte de su psicología picaresca, un acendrado pragmatismo evidenciado en uno de muchos momentos, al enterarse de la noticia de la muerte de su hermano, a quien siempre criticaba por no seguir su mismo patrón de comportamiento:

[. . .] hizo visible cierta rara, chocante complacencia, al ver que los hechos habían venido a corroborar su bodegueril criterio de que mi padre nunca hubiera podido abrirse paso en la vida, porque no la entendía, y, en vez de haber venido a Cuba a trabajar en el comercio, a ganar dinero, púsose a perder tiempo. Primero, formando hogar con inconveniente premura; luego con sus extrañas opiniones políticas, que le llevaban a disculpar [. . . el separatismo de los cubanos, y, para colmo de disparates, aquel de haberse ido al Norte en busca de una carrera. [. . .] ¿Qué más carrera que la del 
productivo comercio a la española, con géneros españoles, en lo que de tierras españolas quedaba en América? Allí le tenían a él de ejemplo. Poco lujo en la ropa, poquísimo en el comer y ninguno en el dormir. ¿Diversiones?, la del "negocio", y para mujer, la negrita o mulatica barata, sumisa y exenta de enojosas complicaciones pasionales. (Generales 33)

Es evidente que estamos en presencia de un personaje utilitario, cuyo comportamiento está guiado únicamente hacia la obtención de su meta: el enriquecimiento económico.

Ese personaje, que reaparece en la vida de Ignacio veintidós años más tarde, ejemplifica al tipo del "doctor" aludido en el título de la obra. A pesar de que Loveira no hace referencia directa al móvil que llevó a don Pepe a "convertirse" en doctor, se infiere que fue su filosofía picaresca quien lo empujó por ese camino. El pícaro siempre quiere sacar provecho de las condiciones sociales imperantes, acepta el status quo y busca su acomodo dentro del mismo. En la sociedad donde don Pepe se desenvuelve, solamente se logra una posición social o política importante si se posee un grado de general o un título de doctor. La primera opción para él es imposible; por lo tanto, opta por la segunda. Esa filosofía se evidencia en la siguiente cita: 
Pues, tantos libros te han chiflado. Vas mal; te lo juro que vas mal, sobrino. Yo no le leído tanto (por más que estudié duro, cuando lo del título; pégale el cuño) y ya me ves. [. . .] Y yo, que al verte rumbo a La Habana, me dije, digo: Vamos, al fin el sobrino ha entendido la vida, y va a La Habana a sacarle producto a los estudios y al veteranismo. (Generales 207)

Otro de los personajes de filiación picaresca que aparece íntimamente relacionado con Ignacio es el Nene. Es éste el personaje que le propone al tío Pepe el ya mencionado negocio de la falsificación de monedas. Uno de los aspectos de la personalidad picaresca que se muestra en este personaje con su actuación en este suceso es su carácter proteico. El Nene se manifiesta como un actor consumado en todas las acciones que realiza con vistas a "timar" a Pepe García. Primero representa el papel de un simple obrero que todos los días antes de irse a trabajar se bebe una ginebra. Todo lleva a pensar en un comportamiento normal, más bien rutinario, sin ninguna relevancia. Cuando el bodeguero lo confronta por pagarle todos los días con una moneda que él cree que es falsa, el otro aparenta que ni siquiera se da cuenta de que paga con el mismo tipo de moneda, cuando en realidad lo hace a propósito. Así manipula la situación y la lleva al punto que quiere. Una vez conseguido el resultado --la confrontación por parte del 
bodeguero--, adopta el papel de un verdadero falsificador de monedas que necesita un socio para el negocio y tienta al bodeguero de manera sutil:

[. . .] yo hago unos pesos, que se los traga el pinto de la paloma. [. . .] Pero, amigo, carezco del pico que se necesita para comprar los materiales en gran escala y hacer dinero en poco tiempo, y tengo que conformarme con ir tirando. iAh; si yo tuviera cien centenes! ¡Si yo encontrara una persona que quisiera "salvarse", sin peligro alguno, y que no tuviera miedo de meter cien centenes! (Generales 25)

Cuando se da cuenta de que don Pepe ha caído en la trampa, se hace acreedor de su confianza al pedirle que lo acompañe a buscar los materiales que necesitan para la falsificación de las monedas. Al llegar a la casa del supuesto estibador, continúa la representación:

--Hola, Seisdedos. Aquí tienes al señor de quien te hablé. Aire de fingida desconfianza en el mulato, $y$ --Oye, chico: no me acuerdo de que me hayas hablado de nadie.

--¿Cómo no, compadre? ¿Ahora vas a salirme con boberías? Déjate de eso; que cuando yo presento a un hombre para un negocio, es porque lo conozco. El señor es un hombre emprendedor, entero, honrado [. . .] 
--Tú sabes que ésta es cosa de peligro.

--Es claro, chico; pero cuando yo vengo con el señor...

¡Vamos!... comprenderás que... [. . .]. (Generales 26-27)

Al reaparecer unos años después como el novio de Mercedes Rubio, el personaje manifiesta otros rasgos picarescos. Se sabe que su comportamiento en la relación amorosa no está en concordancia con los códigos de la decencia y el respeto establecidos por la sociedad de la época; y además tiene una querida que es prostituta, a quien maltrata física y verbalmente. Por otra parte, en un acto político que se celebra en Placeres, ataca por sorpresa a Ignacio con un puñal, hiriéndolo sin que éste pudiera hacer nada por defenderse. Este comportamiento criminal lo relaciona con algunos pícaros, como el Buscón de Quevedo.

Este personaje ejemplifica a los "generales" a que se refiere el título de la novela. Después de la agresión a Ignacio huye a la manigua para evadir el castigo --otra acción picaresca--, y se convierte en insurrecto. Cuando termina la guerra ha alcanzado el grado de general. Se casa con la hija de un tabacalero "[ . . ] por el brillo de sus centenes [. . .]", y [. . .] vive públicamente con [. . .] (la) [. . .] mulata que era su querida antes de la Revolución [. . .]" (Generales 205).

El carácter picaresco del Nene lo resume Ignacio al comentar: "Antes de la guerra, timador, pendenciero, chulo, jugador. Después de la guerra, [. . .] se ha enriquecido con el sólo anhelo de satisfacer deseos 
innobles, y para hacerlo no he tenido escrúpulos en contribuir a la corrupción del medio en que vive" (Generales 204). Más tarde, hace un recuento de las acciones del personaje, la mayoría representativas del comportamiento picaresco:

¿Quién es el Nene [. . .]? Y a la mente me vienen, como una réplica terminante, las páginas más notables de la historia de este hoy digno miembro del Congreso: aquel magistral timo de la guitarra a mi tío; aquella típica pendencia en el juego de pelota; aquellas indignidades contra la pobre Mercedes; aquellos escándalos con la mulata; aquella gloria de irse a la manigua después de darme una puñalada placera y luego su gran hoja de servicios en la paz: caciquismo, poligamia multicolor, fomento de la vagancia política, corrupción del sufragio, convulsionismo profesional. (Generales 234)

También aparece como personaje de perfil picaresco Carlos Manuel Amézaga, compañero de escuela de Ignacio García. Este personaje está presente en la narración en dos momentos de la vida de Ignacio, y a pesar de no ser un personaje muy desarrollado, su carácter picaresco se evidencia desde los inicios, y así lo anuncia el autor: "[. . .] es de los que irán lejos" (Generales 12). ${ }^{2}$

Carlos Manuel Amézaga es hijo de español y un anticubano empedernido, cualidad que se hace patente con una expresión que gusta 
decir: "Para el cubano, un gallo y una baraja, y listo" (Cenerales 8). Debido a su ideología, desde que conoce a Ignacio, lo hace víctima de todas sus mañas de pícaro, una de las cuales es el fingimiento. Inicia un conflicto con Ignacio por un chiste que el otro no celebra, solamente porque necesita un motivo para pelear e imponerse; sin embargo, después demuestra ser un cobarde, como muchos de los pícaros. Como piensa que Ignacio le tiene miedo, lo provoca; pero cuando éste le pegó a su amigo, "[. . .] emprende vergonzosa carrera" (Generales 11).

A partir de ese momento, la dinámica de la relación entre ambos personajes cambia. A Carlos Manuel no le conviene que se sepa el incidente y se reconcilia con Ignacio, pero solamente en apariencias, pues como comenta este último:

Maquiavélicas [. . .] fueron aquellas paces. Desde entonces, loyolesco fue el proceder de Amézaga, cuya oculta mano veía yo en una serie de cosas rara que me pasaban en aquellos días en que más me prodigaba él sus lisonjas. A cada rato encontraba yo en mi pupitre, o en mis bolsillos, comprometedoras décimas y canciones de letra separatista. Cierta vez, al ponerme la gorra, hallé prendida al forro de aquélla un retrato de Maceo. $Y$ una tarde al pasar por la ferretería del padre de Carlos Manuel, un dependiente que hablaba con éste, me dijo con frase del más intencionado 
sarcasmo: --¡Ah! ¿Este es el que presume de ser tocayo del cabecilla Agramonte? (Generales 11)

Todas estas trampas estaban encaminadas a perjudicar la reputación de Ignacio.

En otra ocasión, Amézaga aprovecha una acción casi inocente de Ignacio para hacer serias acusaciones en contra de él: "Primero le tiró una trompetilla al dependiente, y luego le hizo muecas al maestro. Es muy enemigo de los españoles, y eso que es hijo de gallego. ¿A que trae en los bolsillos láminas o versitos insurrectos?" (Generales 17). Ante esta acusación, Ignacio descubre las trampas de Carlos Manuel con respecto al pedazo de bandera española que le encuentran en uno de sus bolsillos: "Eres un sinvergüenza, que mientes descaradamente al amparo de tu padre. [. . .] el pedazo de bandera me lo has echado tú encima, como lo has hecho otras veces con varias cosas para hacerme daño" (Generales 18).

La relación entre estos dos personajes queda interrumpida después de estos hechos y no se reanuda hasta varios años después cuando Amézaga visita Placeres como parte de la campaña política del partido autonomista. Es ahora un gran orador y de él, así como de José Inés Oña, se dice que "[. . .] son dos sinsontes; ${ }^{3}$ dos esperanzas del partido y de Cuba" (Generales 72). ${ }^{4}$ 
Amézaga es un futuro doctor, pero ya casi lo es "[. . .] por la figura severísima, el andar tambaleante y la pose académica [. . .]" (Generales 92) que adopta cuando tiene que pronunciar su discurso en el mitin de Placeres. En su biografía, Ignacio señala la calidad del discurso que sugiere un fuerte carácter teatral:

Bien, bien trabajadito [. . .]. Cualquier malicioso diría que no es improvisado, por lo magistral de la declamación y la facilidad de palabra: períodos redondos, empezados con voz grave, campanuda, que va en crescendo artístico hasta coronar una frase efectista, en carusiano agudo, de resultados magníficos. (Cenerales 92)

$Y$ transcribe fragmentos del contenido con la intención de desenmascarar al farsante: "Los autonomistas cumplimos honrada y virilmente nuestro deber, siendo firmes con nuestra divisa de Orden y Libertad, y denunciando a los conspiradores que en el extranjero fraguan nuestra ruina y nos señalan caminos de lágrimas y sangre" (Generales 92). Con esta conducta se ilustra el carácter proteico de Amézaga que adopta una posición que está lejos de sentir, solamente porque le conviene para lograr un lugar importante en la sociedad.

El doctor Cañizo es otro personaje de Generales y doctores que se comporta de forma picaresca. Es el médico de cabecera de Ignacio, quien lo describe: "[. . .] cubano, treinta y cinco años, alto, vientre adiposo, 
chaquet, bombín y bigote negrísimo, brillante de pomada; emplea mucho su latín macarrónico, en la conversación y en las recetas; es autonomista a macha martillo [. . .]" (Generales 101). Esta descripción contrasta con la que hace Ignacio, acto seguido, del doctor Pons, que aparece caracterizado de la siguiente forma: "[. . .] español, cincuenta años, figura donquijotesca, terno blanco, pajilla, pera y bigote grises; es el ateo oficial del pueblo, y con respecto a la política cubana se adelanta a Pi y Margall" (Generales 101). ${ }^{5}$

Este recurso de describir a dos personajes tan dispares, uno a continuación del otro, le sirve al autor para resaltar el carácter picaresco de Cañizo que se hace manifiesto durante el transcurso de la narración, especialmente en el campo de los ideales políticos. Al señalar Ignacio la postura autonomista de Cañizo, se sientan las bases para demostrar cómo el personaje, siguiendo un proceder proteico y oportunista, logra un lugar importante en la sociedad de la época sirviendo a la causa independentista, es decir, tomando como trampolín la gesta patriótica para beneficiarse sin haber hecho ningún sacrificio.

Cañizo se convierte en insurrecto, actitud reñida con su posición autonomista inicial, y desde el principio presenta rasgos picarescos: "[. . . es un majá [. . .]" (Generales 107)6 , capaz de cualquier traición y por eso hay que vigilarlo. Sin embargo, cuando Ignacio se incorpora al ejército libertador y tiene que ir a un hospital en la manigua por hallarse 
enfermo, allí encuentra a Cañizo, luciendo ya el grado de comandante y viviendo "[. . .] todo lo bien que se puede vivir en la manigua" (Generales 181). El propio personaje comenta los privilegios de que disfruta mientras que otros hombres arriesgan su vida por la libertad de Cuba: Aquí no tenemos jefes, trabajamos poco, tenemos segura la comida y algunas cosas más; porque el hospital tiene sus comisiones, que recogen por las prefecturas y los campamentos, velas de cera, raspadura, tasajo de vaca, viandas, tabaco. Además, aquí se siembra algo, y tenemos cuarenta vacas intocables. Tenemos opción al amor, con sólo un viajecito a la prefectura [. . .]. Aquí no hemos tenido nunca los peligros de los hospitales de sangre en Las Villas y la Vuelta Abajo; de ésos que a cada rato pasan a cuchillo los españoles. [. . .] Esto está muy resguardado. (Generales 184)

En una carta a su madre, Ignacio critica a los cubanos que lograron alcanzar el rango de general sin hacer grandes sacrificios por la patria y pone de ejemplo a Cañizo:

Después de cansarse de decir que la República sería un Haití, una merienda de negros y qué sé yo cuántas cosas más, [ . . .] ahora es más ultramontano que el Papa. No hace más que limpiar las estrellas, escribir sus fabulosas hazañas en un gran diario de campaña e inflar discursos de suicida 
espartano. Con el grado último, Cañizo será teniente coronel, y creo que con menos derecho que el que tengo yo para ser capitán. Porque, siquiera, yo vine al monte desde un lugar en que era perfectamente inmune a las balas y a los odios de los españoles; en cambio él, [. . .] ha sido libertador muy a pesar suyo. (Cenerales 193)

Después de terminada la guerra y cuando Ignacio viaja a La Habana, vuelve a encontrarse con Cañizo, convertido en un pícaro que ha logrado el éxito:

Doctor y general. [. . .] Otra gran fiera. [. . .] Tiene entrada en todas partes. Con la gente de sociedad, los masones, la iglesia, los espiritistas, los obreros. [. . .] Es el gran socialista. Por más que en su vida va a un centro obrero, y que vive en el Prado. Tiene sus debilidades: le gustan las pollitas, muy pollitas; cosa que le cuesta algunos escándalos. Pero él es Cañizo, General y Doctor. ¡Inexpugnable! (Generales 210) Hace público su actuar picaresco:

Me ha contado, descaradamente, cómo ha llegado a General, desde Comandante, en tiempos de paz. Cuando se acabó la insurrección le dieron un grado: Teniente Coronel. Poco a poco fue suprimiendo lo de Teniente, y quedándose en 
Coronel solo. Después vino la de Agosto, se escondió allá por los manantiales del Sagua, y salió General. (Generales 210$)^{7}$ Y predica la filosofía picaresca, haciendo, a la vez, evidente su pragmatismo:

Por fin vienes a hacer valer tus méritos en La Habana. [. . .] con estar en un pueblo hablando en veladitas patrióticas, despidiendo duelos de lumbreras aldeanas y publicando versitos y editoriales en periódicos efímeros que nadie lee, no se va a ninguna parte. [. . .] Eres joven, y el momento es propicio. Tírate un salvavidas al Partido Nacionalista. Yo haré que te suelten una cuerda. Te agarras bien. Hablas mucho por ahí, de tus hazañas en la guerra; procura que te cojan miedo; suéltate un disco en cuanto mitin se te presente. Ya sabes: cuatro lugares comunes de barniz patriótico, unos pujos moralistas [. . .] diciéndole a la gente que hay que renovar la empleomanía, y vas para arriba como la espuma. (Generales 214-215)

Después de realizar el análisis de los personajes de Cenerales y doctores, se llega a la conclusión de que la mayoría de ellos son, más que personajes, tipos, "[. . .] caracteres de sólo dos dimensiones, sin honduras, sin relieve, sin perspectiva" (Martínez 1030). Estos personajes los utiliza Loveira para ilustrar la conducta de algunos ciudadanos de la 
época, especialmente los oportunistas que se valían de un título de doctor --quizás suciamente adquirido--, o de un rango de general inmerecido, para hacerse acreedores del derecho al poder político, económico y social. Así, "Amézaga representa al pedante de malas intenciones [. . ], al hipócrita acomodaticio que cambia de opinión política como de chaqueta y se adapta a todo con tal de triunfar [. . .]. Nada lo hunde; es lo que en Cuba se llama el 'hombre de corcho"' (Martínez 1031). Por su parte, don Pepe encarna a otro tipo de la sociedad colonial: el bodeguero "[. . .] inevitablemente español, siempre ignorante y nunca limpio de cuerpo ni de alma" (Martínez 1034). Este personaje cumple en la novela una doble función pues al final de la novela representa al "[. . .] español convertido en potentado en los primeros tiempos de la República" (Martínez 1034). al Nene lo utiliza Loveira para ejemplificar al "[. . .] prototipo del político criollo [. . .], hombre de acción corrompido y depravado, verdadero ejemplo del perdido que precisamente por serlo triunfa en la política republicana" (Martínez 1035). Por último, el doctor Cañizo encarna el binomio doctorgeneral, tipo abundante durante los primeros años de Cuba republicana. Este personaje es el que exhibe una postura más antiheroica, más acorde con el comportamiento picaresco, ya que utiliza su título para beneficio propio. Por añadidura, esta conducta inmoral se le premia, otorgándole un rango militar máximo, sin siquiera haber expuesto su vida por la 
patria o por sus compatriotas, lo que le facilita la escalada política y social.

Se hace evidente que el comportamiento picaresco está en absoluta consonancia con la psicología de los personajes creados por Loveira, cuya intención es la de criticar a ciertos tipos de la sociedad cubana de su época a quienes él consideraba negativos por su forma de actuar carente de principios e ideales nobles.

\section{Juan Criollo.}

Esta novela es la última y la mejor de Carlos Loveira, y, a juicio de Marcelo Pogolotti "[. . .] una de las novelas cubanas más valiosas" (27). Es ésta una obra de un

[. . . ] amplio planteamiento social, [. . .] cuyo protagonista, a través de las más variadas peripecias de su vida, ofrece a la vez el retrato de un tipo tan frecuente como negativo, de abulia, sensualismo y acomodamiento egoísta, y una serie de visiones del proceso de las diferentes clases sociales cubanas del final de la colonia y los primeros tiempos de la República. (Lazo 233)

Por su parte, Lucrecia Artalejo considera que esta obra es una "[. . .] reescritura de Generales y doctores [. . .]" ya que "[. . . el tema central de 
ambas novelas es el mismo: la vigencia del disimulo tanto en la sociedad colonial cubana como la republicana" (126). ${ }^{8}$

Como acertadamente comenta Juan J. Remos, esta novela es "[. . . ] la historia del cubano trepador y aventurero, que recorre muchos peldaños de la escala social desde la condición de sirviente, hasta la empinada de Representante a la Cámara" (Historia 3: 307). El personaje a quien se refiere Remos es Juan Cabrera, quien "[. . .] protagoniza un tipo picaresco en guerra perpetua con el medio, [. . . q que finalmente se decide a ser Juan Criollo, a entrar en la bachata, en la orgía de los pillos nacionales [. . .]" (Alvarez 23).

Aunque la narración se lleva a cabo desde una perspectiva omnisciente, detalle que la aparta de la picaresca tradicional, la misma se inicia a partir de la infancia del protagonista y concluye en su edad adulta, cuando después de llevar una vida itinerante de aprendizaje, ha alcanzado "la cumbre de toda fortuna". Desde el inicio de la novela se percibe claramente que las circunstancias de vida y el comportamiento de Juan Cabrera guardan una estrecha semejanza con las de algunos pícaros clásicos, especialmente con Lázaro de Tormes.

Cuando se inicia la narración Juan es un niño de seis años, huérfano de padre. Enseguida el narrador informa al lector sobre el origen de este niño que, como es común en muchos pícaros, es de baja extracción social: "[. . .] era hijo único de Manuel Cabrera, barbero 
español, muerto [. . . thes años antes [. . .]" (Juan Criollo 1) y de Josefa Valdés, lavandera que "[. . .] luchaba por la vida, aferrándose al empeño de ser 'honrada y trabajadora', de sostener sólo a fuerza de batea y plancha un hogar propio e independiente [. . .]" (Juan Criollo 2). Sin embargo, a pesar de los esfuerzos de la madre, Juan pasa hambre, otra condición recurrente en numerosos pícaros clásicos, y ésta termina prostituyéndose. $^{9}$

A pesar de su corta edad, el personaje anda en casi continuo vagabundeo por las calles de su barrio, donde se reúne con un grupo de pillos que lo inician en las artes y mañas picarescas. Muchas veces "Juan [. . .] atravesaba un vecino solar yermo [. . . para traer los mandados de la bodega, donde aprendía un escogido lenguaje, la virtud del matonismo, la alta nota cívica que es el insulto a la madre ajena [. . .]" (Juan Criollo 2). Una vez terminados los encargos, cargado con las compras, [. . .] emprendía Juan su regreso. Regreso de dos horas para dos cuadras; porque faltábale todavía algún aprendizaje antes de almorzar: el recién importado base ball en un one-two-three de 'placer' con la más revuelta y mal hablada golfería del barrio; el 'siló', los 'botones' y 'las tres cartas'10, en cualquier callejero grupo de fulleros y viciosos del más bajo linaje [. . .]. (Juan Criollo 18) 
Por las tardes, después de almorzar, "[. . . ] Juan andaba nuevamente en la calle [. . . ] con una semidesnuda y policroma pandilla de granujas de su edad y de su barrio. La pandilla realizaba toda clase de maldades visibles y ocultas, lícitas y peligrosas [. . .]" (Juan Criollo 19). De esta manera se va adiestrando y adentrando el niño en la vida picaresca.

La trayectoria vital del pícaro clásico se inicia, casi siempre, con un estado de inocencia primaria, de ingenuidad y nobleza que va perdiendo a medida que tiene que enfrentarse con un medio que le es hostil y lo condiciona irremediablemente. Poco a poco, debido a su encuentro con la realidad, el pícaro va aprendiendo y se va degenerando, llevándose a cabo un doble proceso inverso: mientras adquiere experiencia, pierde inocencia. El inicio de esta metamorfosis se advierte claramente en el personaje de Juan Criollo. Al narrar las trampas que la pandilla a la que pertenecía Juan le hacía al chino vendedor de dulces, el narrador comenta la actitud compasiva del niño hacia éste: "[. . . ] sólo Juan, instantáneamente, solía tocar la sensible fibra de la piedad en aquellos sus compañeros, [. . .] al exclamar [. . .] en hondo, sincero, remordedor suspiro: --¡Pobre chino!" (Juan Criollo 21).

Con la muerte de la madre de Juan se inicia otra etapa en la vida del personaje. Debido a la hospitalización de ésta, Juan fue llevado a vivir, de forma provisional, al hogar de la familia Ruiz y Fontanills, y después de su fallecimiento se quedó allí en calidad de recogido y criado. 
A partir de este momento, y con sólo diez años de edad, comienza para él una vida itinerante, con diferentes familias o amos, equivalente a la de varios pícaros del Siglo de Oro.

Es curioso observar que muy pronto, Juan tiene una experiencia que remite al lector inmediatamente a la vida de Lazarillo de Tormes. A los pocos días de su instalación en la casa de Roberto Ruiz, el niño comete una de sus travesuras y una vez la familia descubre el acto picaresco, lo castiga obligándolo a escribir mil quinientas veces la frase: "Debo portarme bien, porque no tengo padre ni madre" (Juan Criollo 73). Es éste un momento de iniciación para Juan que lo hace meditar en su orfandad y darse cuenta de que él no tiene nadie que vele por él. Al igual que lo hizo Lázaro al recibir el golpetazo contra el toro de Salamanca y decir: "Parescióme que en aquel instante desperté de la simpleza en que, como niño dormido estaba. Dije entre mí: 'Verdad dice éste, que me cumple avivar el ojo y avisar, pues solo soy, y pensar cómo me sepa valer"' (Lazarillo de Tormes 23), Juan despierta de su inocencia y comienza a absorber "[. . .] las lecciones de aquel medio que el juego de la vida le deparaba" (Juan Criollo 74).

Se observa tempranamente en Juan Cabrera un rasgo que está ausente de la caracterización clásica del pícaro y que, sin embargo, en este personaje está íntimamente relacionado, en numerosas ocasiones, con su comportamiento picaresco. Este rasgo es el erotismo. Desde 
tempana edad Juan comienza a aventurarse en el ámbito erótico y su primera aventura de esta índole es la causa de su traslado fuera de La Habana a la finca Los Mameyes. El episodio del supuesto noviazgo entre Juan y Nena, una de las nietas de Roberto Ruiz, y el posterior descubrimiento de la relación por parte de un tío de la joven, llevan a don Roberto a tomar la decisión de separar a los jóvenes definitivamente, mandando a Juan lejos. De esta manera culmina una etapa en la vida de éste y se inicia otra, donde el joven continúa su trayectoria picaresca. Una vez instalado en la finca Los Mameyes, "Juan viose empujado a pillear nuevamente por los escondites del arroyo, de caminos, guardarrayas y arboledas" (Juan Criollo 167). Sin embargo, esta vida duró solamente hasta el inicio de la zafra, ya que Juan tiene que trabajar como pesador de caña. Es en este entorno campestre donde se manifiesta por segunda vez el erotismo del personaje personalizado en Petra, la cuñada del mayoral. Aunque el romance se inicia de manera casi inocente, Juan exhibe una conducta picaresca con respecto al mismo en varias instancias, como cuando se acercaba "[. . .] en puntillas [. . .] para ir a avizorar, al través de las rendijas de las puertas, a la mulatica desnuda, en casero baño de batea [. . .]" (Juan Criollo 179-180). Después de numerosos encuentros a escondidas en que los jóvenes burlaban la vigilancia del mayoral y su mujer, Petra, en un arranque de compasión, se entrega a Juan, y a partir de este momento mantienen la convivencia, 
oculta por cierto tiempo, mediante burlas y subterfugios. Una vez descubiertos por Caridad, Juan huye cobardemente, abandonando a su amante embarazada. Esta actitud pone de relieve el comportamiento picaresco del personaje que demuestra su cobardía al no luchar y defender a la amante de la furia del mayoral así como su pragmatismo y falta de escrúpulos al abandonar, no solamente a la joven que se había enamorado de él, sino al hijo fruto de esos amores, con tal de librarse él de las consecuencias que podía traerle esta situación.

De regreso en La Habana, Juan reinicia su relación con la familia Ruiz y Fontanills, al convertirse en el "empleado" de Adolfo. Pronto descubre una posibilidad de acomodo y se dedica a utilizar sus mañas de pícaro para alcanzarla. Surge la posibilidad de abandonar la isla con destino a Yucatán, tierra de donde es originaria la novia de Adolfo y destino de la pareja después del matrimonio. Juan se dedica a engatuzar y a hacerse querer de Carmen con el objetivo de que no lo dejen en La Habana: "Juan estuvo todo el día en casa de las yucatecas, trajinando, afanoso, formalísimo, atentísimo; atándolas a su suerte por el afecto, por la comparticipación de la felicidad, por el halago en el elogio de cuanto salía de la habitación" (Juan Criollo 255).

La metamorfosis picaresca de Juan se hace más evidente aún después de su llegada a Yucatán. Apenas llegado a esa tierra, y aprovechando que Nena ha viajado con ellos, trata de sacarle provecho a 
unos papelitos que ella le había escrito durante su "presunto noviazgo", y que él aún conserva. Cuando la joven manifiesta interés por saber el paradero de los, para ella, comprometedores documentos, Juan decide llevarla a su cuarto con el pretexto de entregárselos cuando en realidad quiere propasarse con ella.

Una vez más, el erotismo de este pícaro criollo es la causa de otro conflicto. Como consecuencia de su comportamiento con Nena, Juan es enviado lejos de Mérida, a un poblado llamado Peto, para trabajar en una finca henequenera. Es ésta otra etapa en la vida del pícaro, ahora con más independencia. Tiene trabajo y siente que está progresando en la escala social. Sin embargo, pronto su erotismo lo lleva a otra acción equivocada: el matrimonio. Juan Cabrera siente una atracción física por Marta, una joven mestiza, con la cual sabe que no puede tener relaciones sexuales fuera del matrimonio, por eso se casa con ella. Aunque a simple vista esta acción no conlleva una actitud picaresca, lo cierto es que en realidad, sí lo es. Juan no se casa por amor; para él el matrimonio es la única posibilidad de lograr la posesión de la joven. Hay en la acción un pragmatismo y una falta de escrúpulos evidente, como se infiere de los razonamientos del personaje antes de decidirse a proponerle matrimonio a la joven:

¿Y si se casase? [. . .] ¿qué cosa más fácil para tener mujer, libre, cómoda, desahogadamente; a la vista de todos y para 
todas las noches? ¿Qué problema era ese? El tenía ya unos ahorros. Si se los gastaba ¿qué? Siempre le saldrían baratísimas las 'veces', iy con una doncellita! [. . .] El no era de Peto, ni de Yucatán, y la guerra en Cuba no iba a durar toda la vida. (Juan Criollo 297-298)

Estos pensamientos de Juan no solamente revelan que se casa solamente para tener una relación sexual moralmente aceptable a la vez que barata, sino que en sus planes no figura la permanencia de ese matrimonio. Para él esta relación será algo temporal, una forma de acomodarse mientras termine la guerra y pueda regresar a Cuba.

Otro factor que contribuye al aprendizaje de Juan y a su tendencia a adoptar una actitud picaresca ante la vida es su amistad con Cirilo, el barbero cubano, autodidacta, que Juan conoce en Peto. Si bien es cierto que es con este hombre con quien Juan se va educando y se adentra en diferentes campos del conocimiento, los consejos de Cirilo influyen de manera determinante en la conducta posterior de Juan. Conocedor de casi todos los pormenores de la vida de Juan y con un falso concepto del evolucionismo, le aconseja a Juan "[. . .] vivir la vida del mejor modo posible [. . .]" (Juan Criollo 310 ), y para eso, según el barbero, Juan tenía que vivir "[. . .] más allá del Bien y del Mal" (Juan Criollo 310$)$. La filosofía de Cirilo al aconsejar a Juan sobre el camino a seguir está en total consonancia con la picaresca, como lo ilustra la siguiente cita: 
No abandonar totalmente, no perder de vista [. . . a la familia que le trajera a Yucatán. [. . .] Alargar, alargar hasta todo posible límite una amistad así, falsa pero explotable. $Y$ en cualquier momento hacer algo parecido con la muchacha de Mérida, sin cursis sentimentalismos ni tontas preocupaciones morales. ¡Bah! No querer acostarse con la misma mujer que se acostase con diez hombres más cada día. ¿Por qué? La hembra humana sólo era . . . eso; una hembra de tantas. [. . .] En todo caso, Juan iba también a dar lo suyo. Por fortuna tenía bastante que dar: estaba en condiciones de dedicarse al donjuanismo profesional. Profesión como otra cualquiera. [. . .] Y en cuanto a que el matrimonio con aquella mesticita [. . . pudiera ser una traba. .. ¡Uh! [. . .] No era preciso mirar mucho para ver, franca y netamente, el porqué de aquel matrimonio. El joven [. . . tenía imperiosa necesidad de mujer. [. . .] El se inclinó a la muchacha que más a mano tenía y que 'mejorcita' estaba entre todas las asequibles. [. . . ¿ ¿O pensaba Juan, un joven blanco, de buena presencia, inteligente, con acaso cuáles grandes posibilidades en la vida, quedarse allí, entre aquellas gentes semicivilizadas, aun después de terminada la guerra 
en Cuba [. . .]? ¡No, hombre! Aquello estaba bien para ir pasando [. . .] el mal tiempo [...]. (Juan Criollo (310-311)

De esta manera, Juan se va convirtiendo en un ser más pragmático, carente de escrúpulos, que aprovecha lo que le conviene de una situación sin tomar en cuenta los motivos y sentimientos de las personas que lo rodean. Estas enseñanzas y su erotomanía lo llevan a abandonar a su mujer con seis meses de embarazo y regresar a Mérida en busca de una mejor vida al lado de Julia, la prostituta que conociera un tiempo antes y que le escribiera prometiéndole "[. . .] goces intensos, [. . .] entregas totales, [. . .] servil rendimiento de bestezuela enamorada, [. . . ] felicidad, única e inacabable, [. . .]" (Juan Criollo 31 5). Sin embargo, para dejarse la puerta abierta por si acaso tiene que volver, le miente a su mujer con respecto a los motivos que lo llevan a la ciudad: "Don Adolfo me manda a buscar. [. . .] si es para quedarme por allá, en cuanto pueda te vendré a buscar" (Juan Criollo 314).

Con su regreso a Mérida, la vida de Juan da un nuevo giro donde el carácter picaresco se agudiza. Su amigo Julián le consigue un trabajo como lector en la tabaquería donde trabaja, pero eso no es suficiente para vivir, y Juan decide sacarle dinero a Julia. Poco a poco, va adquiriendo la imagen típica del chulo. Le pone "[. . .] empuñadura de plata a un grueso bastón de yaya, [. . .]. Después comienza a usar ropa interior de colorines, una moneda de oro, como dije, y media melenita de 
corte alto y recto en la nuca" (Juan Criollo 321). Además, la amistad con los tabaqueros lo inicia en varios vicios: "[. . . fuma, juega y pierde horas enteras en hablar y discutir gritonamente, en torno de las tesis más triviales, menos edificantes, plenas de lamentables apasionamientos de solar y barracón" (Juan Criollo 321). Lleva esa vida libertina y picaresca hasta que se ve involucrado en un caso judicial por la agresión al dueño del burdel donde trabaja su mujer y lo meten en la cárcel.

Una vez lograda la independencia de Cuba, Juan es liberado, gracias a las influencias de Julia, y regresa a La Habana. En esta nueva etapa de su vida, Juan tiene que enfrentarse con una sociedad en estado de transición donde su actitud picaresca se recrudece. Su situación es la de muchos emigrados que regresaron al país sin nada. Necesitaba trabajar para ganarse la vida, pero su poca educación y su carencia de grados militares eran un obstáculo para conseguir un empleo decente y no le queda más remedio que emplearse en lo que sea. En medio de esta miseria, la actitud picaresca lo va sacando a flote. La misma se manifiesta en numerosas instancias donde Juan, haciendo despliegue de su carácter proteico, adopta diferentes papeles, entre ellos el de poeta e intelectual, con el fin de ganarse a gente que pudiera ayudarlo, aunque fuera a matar su hambre. Esto se hace patente en la relación que Juan establece con un dependiente de una fonda de chino que estaba muy enamorado de una joven culta, al cual Juan 
[. . .] le hizo creer que era poeta y escritor en desgracia, y le redactaba los borradores de las cartas para la novia, y de algunos versos, que exaltaban la generosidad del dependiente, al exaltarle la admiración por el poeta. Las cartas eran adaptaciones de un tomo de Jorge Sand, que Juan había traído de Mérida junto con otro de Campoamor, de donde textualmente copiaba una o dos "Doloras", diarias con destino a su hombre. (Juan Criollo 365-366)

A cambio de las cartas y los versos plagiados, el dependiente le daba a Juan comida gratis para él y su compañero de cuarto.

Entre los personajes que ejercen influencia en el comportamiento de Juan y lo guían hacia el modo de vivir picaresco en esta etapa de su vida está Julián, su amigo de la infancia. Julián ha logrado el acomodo en la nueva sociedad cubana y le aconseja a su amigo que proceda con disimulo y fingimiento: "No cree uno en la misma moral. En nada. Pero se lo calla; dice lo contrario, y hace idem. Así, más nietzchano que yo nadie. Así son todos los que triunfan; los que le dan la razón a Nietzche. Tu, di que crees en todo; pero echa hacia adelante, por todos los caminos y a toda costa" (Juan Criollo 373)." Julián se ha dado cuenta de que en la sociedad republicana la política ofrece un filón para progresar y obtener un puesto importante y ya anda involucrado con el partido ganador, y le recomienda a Juan que haga lo mismo. Es este personaje quien lo 
convierte en orador de mítines populares; pero al final "[. . .] el cubano Juan Cabrera cayó en un renglón de las nóminas del Estado" (Juan Criollo 390), y abandona la oratoria y las reuniones políticas porque a él "[. . .] no le tiraba la política que necesitaba comenzar por abajo, con intrigas y oratorias comprapleitos" (Juan Criollo 390). Su pragmatismo lo llevaba a asegurarse un sueldo que le permitiera comer y vivir decentemente, mientras proseguía su escalada en el esquema social; y su erotismo a buscar acomodo en el terreno afectivo, y para esto recurre nuevamente a sus mañas picarescas. La joven a quien pretende es Julita, una compañera de trabajo. La joven es víctima de las mentiras de Juan que, con intención de conquistarla, no solamente le ha escondido su condición de huérfano recogido, contándole mentiras "[. . .] sobre su pasado de muchacho con familia, con casa, [. . .] para dignificarse ante los ojos de ella" (Juan Criollo 393), sino también ocultado todos los detalles de su vida sentimental, incluido el matrimonio en Peto.

Sin embargo, Julián lo anima de nuevo a meterse en la política que según él, es el único camino para triunfar en Cuba: "Para asegurarte tienes que hacer política. Dicen que en España el hombre pobre y emprendedor no tiene más camino que el teatro o los toros. Pues en Cuba, la política" (Juan Criollo 393), y Juan, decide desempeñar el papel de político una vez más: "Discurseó, redactó manifiestos, e hizo de tripas corazón, con un cuarenta y cinco en la cintura, en un colegio electoral 
[. . .]" (Juan Criollo 394). ${ }^{12}$ Con esta nueva actividad se le empiezan a abrir las puertas del éxito. Primero vino otro nombramiento que traía un aumento de sueldo, y de encargado de revisar los periódicos con noticias de la Secretaría en que trabajaba, pronto pasó a ser él el redactor, demostrando ciertas destrezas para escribir.

Poco a poco, Juan se va afianzando en una posición de poder. Su atracción hacia Julita lo lleva a considerar la posibilidad del matrimonio, a pesar de los problemas legales que le puede traer, y decide hacerse periodista como un medio para evitar que los hermanos Ruiz puedan hacer algo contra él, pues ha "[. . .] observado que el periodista era hombre poseedor del respeto ajeno, porque era hombre temido" (Juan Criollo 397). Para lograr este propósito utiliza las influencias de sus amigos periodistas y una recomendación de Julián.

Cuando inicia sus planes de matrimonio, ya queda muy poco del Juan pobre, muerto de hambre que regresó de Mérida. Tiene suficiente dinero en el banco para comprar una casa y para que su futura esposa no tenga que trabajar más. Pronto llega Juan a "[. . .] Oficial Quinto y rápidamente a Jefe de Negociado [. . .]" (Juan Criollo 404), pero el aumento de la familia con un par de hijos provoca estrecheces económicas en el hogar, y Juan se empeña "[. . .] en continuar ascendiendo en la escala burocrática, y en algún día abrirse paso, en un periódico, con su pluma" (Juan Criollo 405). El tedio del hogar lo lleva a 
refugiarse en la lectura y la escritura y así comienza a escribir, también con la intención de ascender un peldaño más en la escala social. Creía que con "[. . .] trescientas páginas saturadas de estilo, de ideas, y de sentimientos fuertes podría subir hasta un alto renglón sinecural, desde donde poder servir a la patria y servirse a sí mismo [. . .]"; pero no fue así, "[. . .] con literatura no se le podía entrar a los padres de la patria [. . .]" (Juan Criollo 409). Después de este último desengaño, presionado una vez más por Julián, que sí ha sabido aprovechar las oportunidades que la política republicana le había ofrecido, y humillado por los hermanos Ruiz y Fontanills, Juan, cediendo a su filosofía acomodaticia y picaresca decide entrar en la política ya en sus años de madurez.

En esta época el personaje se presenta más como el pícaro barroco, con una gran dosis de desengaño que lo lleva a aceptar la idea de que "[. . .] es condición de vida la de adaptarse al medio" (Juan Criollo 431) si se quiere lograr un lugar importante en la estructura social. Este desengaño se hace aún más patente en el personaje cuando le recomienda a su mujer que, si él llegara a faltar, le enseñe a su hijo la que, según él, es

[. . .] la más profunda máxima de todos los tiempos: "Si puedes, haz dinero honradamente. Si no, haz dinero". Con dinero, mal o bien habido, nos tratan los más austeros y descollantes sujetos; [. . . . Con dinero se consiguen 
diplomas, presidencias, condecoraciones. [. . .] Con dinero, únicamente se es libre de veras, digno de veras, hombre de veras. (Juan Criollo 432)

Como parte de ese adaptarse al medio, toma dos decisiones. La primera, meterse "[. . . en la única y rápida carrera de la política [. . . ]" (Juan Criollo 433), la segunda, optar por el pseudónimo de "Juan Criollo" para darse a conocer como escritor de panfleto, al servicio de unos ideales que no son los suyos. Fueron esas dos decisiones de perfil picaresco las que al final llevaron a Juan a la cima del éxito:

Cinco años después, Juan Cabrera lleva cuatro de Representante, y comienza a meter un pie en el Senado. Tiene tranquila la conciencia, porque manda media colecturía a Peto; le paga una casita a Petra y tiene al [. . . hijo pardito en un Negociado de Obras Públicas. Tiene a Julita, con cuenta abierta en El Encanto, [. . .]. Al Nene, finalizando el bachillerato [. . .]. A la Nena, con profesora de francés e inglés, y profesor de canto y violín. Tiene una rubita de cutis de rosa [. . . ] en casa de dos pisos, con piano y criados, [. . .]. Tiene acciones, colonias, tiempo para hacer literatura y diez casas propias, [. . .]. Tiene un solitario de mil pesos, dos máquinas, [. . . ] y cincuenta "fluses" de dril número cien. (Juan Criollo 436) 
Además del protagonista, en la obra aparecen otros personajes que presentan un perfil picaresco. Uno de los más interesantes es Julián, especialmente por la visión que manifiesta con respecto al papel que desempeña la política en la vida del país y que la enlaza con Generales $y$ doctores. Este personaje lleva una vida muy parecida a la de Juan Cabrera desde la infancia hasta su estancia en Mérida; sin embargo, al regresar a Cuba, inmediatamente se da cuenta de las posibilidades que encierra la participación en la política para un hombre como él, pobre, de pocas letras y que ni siquiera ostenta un rango militar, y no vacila en meterse de lleno en ella. Su carácter picaresco se pone de manifiesto cuando admite abiertamente el tipo de vida que llevan los políticos, disfrutando del tesoro público con impunidad, sin que nadie se atreva a cuestionar su comportamiento debido a su gran influencia.

Por último se debe mencionar como personajes de corte picaresco, pertenecientes a la clase social elevada a algunos de los miembros de la familia Ruiz y Fontanills. El viejo Roberto, es un ejemplo del hombre, erotómano que no tiene escrúpulos de ningún tipo cuando se trata de conseguir una mujer, como tampoco los tiene cuando va dejando hijos abandonados por el mundo. Es hipócrita y pragmático. Toda su moral es de puertas para adentro, con su familia. Sus hijos, siguiendo el ejemplo del padre, tenían varios amoríos a la vez, mientras se hacían pasar por hombres intachables y de gran moralidad en el seno de su familia. 
Adolfo, por ejemplo, a pesar de sus buenos sentimientos para con Juan, no vacila en aprovechar la oportunidad que se le presenta, cuando estando casi totalmente en la ruina, conoce a la rica yucateca en condición de cliente que necesita un abogado:

Con ojos de águila y bolsillo necesitado, [. . . le hizo la corte a la meridana, rápidamente, vorazmente, y el matrimonio se preparó a toda marcha, para darle al hombre [. . .] estos [. . .] dones: [. . .] una salvadora inyección de oro mexicano, [. . .] el inmejorable pretexto de aquel matrimonio con extranjera, para abandonar la Isla, sobre firme base económica [. . .].

(Juan Criollo 236-237)

Por último, todos los miembros varones de la familia, incluyendo los nietos, logran colocarse en posiciones favorables dentro de la política nacional y en el comercio, utilizando el recurso de tener un hermano, teniente coronel y mártir de la Guerra de Independencia, y de ser hijos y nietos de un veterano de la Guerra de los Diez Años, hecho éste que los coloca en la misma categoría de algunos de los personajes de Generales $y$ doctores.

\section{Conclusión.}

El estudio de la tipología que presenta la novelística de Carlos Loveira, a partir de una visión picaresca, revela que muchos de los 
personajes que manifiestan ese perfil son tipos tomados de la realidad social de la época. La mayoría de ellos tienen como objetivo fundamental lograr un lugar importante en la estructura social imperante, por medios no convencionales, independientemente de la clase social a la que pertenecen por su origen. De esta manera, en Generales y doctores, los personajes picarescos le sirven al escritor para ejemplificar a dos tipos que en los primeros años de la república, lograron acceder a puestos cimeros de la sociedad, utilizando bien un rango ganado inmerecidamente durante la guerra, o un título de doctor que raramente se ejercía. Estos personajes son representativos de diferentes orígenes étnicos: cubanos y españoles; de diferentes razas: negros y blancos, y de diferentes posiciones sociales: ricos y pobres.

En Juan Criollo, el personaje protagónico puede llamarse el "hermano cubano" de Lázaro de Tormes. Este personaje no es solamente pícaro por su comportamiento acomodaticio y pragmático después de adulto, sino por todas su condiciones de origen y vida. Al analizar la novela se advierte que la trayectoria vital de Juan Cabrera y la de Lazarillo tienen numerosos puntos de convergencia, a pesar de las diferencias de tiempo y espacio existentes entre ambas, entre ellos, su baja extracción social, su temprana orfandad, su vida itinerante y su arribo a una posición exitosa en la edad adulta. 
Según la visión que se desprende de las novelas estudiadas, para Carlos Loveira, el comportamiento picaresco es la consecuencia de una serie de condiciones económicas, políticas y sociales que no ofrecen al individuo posibilidades de éxito y lo fuerzan a buscar alternativas de vida que de alguna manera lo sitúan en la marginalidad. Esta visión se agudiza en Juan Criollo, que es mucho más pesimista en cuanto se refiere a la situación del individuo en la sociedad cubana de principios del siglo XX. A pesar de su carácter picaresco, Juan Cabrera se presenta como una víctima, y como comenta Carlos Ripoll en su "Estudio Preliminar" a la obra: "el mismo desenlace de la obra confirma la imposibilidad de suprimir las calamidades que arrastran al impotente protagonista. Las fuerzas más negativas hacen claudicar a Juan Cabrera e incluirlo, con sus rebeldías inútiles, en el río destructor de la vida cubana de aquella época" (XVII). 
Notas

' Es interesante señalar la ironía que encierra este comentario de Ignacio, al referirse a "la honradez al uso", cuando en realidad lleva el significado implícito de utilizar cualquier recurso disponible para enriquecerse.

2 Esta afirmación es sinónima de las que abundan en la picaresca tradicional como "medrar" y "llegar a buen puerto", y al usarla, Loveira anticipa el carácter picaresco del personaje.

${ }^{3}$ Esta expresión es equivalente a decir que alguien es un orador elocuente.

${ }^{4}$ Curiosamente, el personaje de José Inés de Oña se perfila durante la infancia como un ser servil que obedece las órdenes de Carlos Manuel, y quien carece, obviamente, de capacidades oratorias por su forma de expresarse, como se advierte en frases como: "Párate ahí, mariquita. Te tiene que fajá con Carlo Manué" (Cenerales 10).

${ }^{5}$ Francisco Pi y Margall, maestro y periodista barcelonés, fue ministro de Gobernación y después presidente de la primera república española, proclamada en 1873 . Siempre fue partidario de la independencia de Cuba.

${ }^{6}$ Esta expresión es sinónima de "vago", "inútil", alguien que no sirve para nada.

' En agosto de 1906 hubo una rebelión en Cuba a consecuencia del caos que se produjo durante las elecciones presidenciales de 1905. Estos hechos culminaron con la segunda intervención por parte del gobierno de los Estados Unidos.

${ }^{8}$ El hecho de que Generales y doctores está narrada en primera persona y Juan Criollo en tercera, llevaría a pensar que la primera sería un recuento más personal; pero no es así. En Cenerales y doctores el proceso histórico cubano ocupa una parte primordial de la narración, mientras que en Juan Criollo éste solamente sirve de telón de fondo para situar la trayectoria vital del protagonista, Juan Cabrera.

${ }^{9}$ La idea de que el niño y su madre pasan hambre se infiere de numerosos comentarios, como cuando se hace referencia a lo que comían: "[. . . almuerzo de arroz blanco, o de ensalada de bacalao [. . .]" (Juan Criollo 2). 
${ }^{10} \mathrm{El}$ siló, los botones y las tres cartas eran juegos de azar prohibidos en la época. La participación del personaje en esta actividad le añade otro rasgo típicamente picaresco: la adicción al vicio del juego.

"Se ha respetado la ortografía de las palabras "nietzscheano" y "Nietzsche" como aparecen en el texto original.

${ }^{12}$ La presencia de Juan en un colegio electoral portando un arma, sugiere al lector que el proceso tiene elementos de ilegalidad y corrupción, y por tanto tiene perfiles picarescos. 


\section{Conclusiones}

La picaresca es un género clave dentro de la narrativa española del Siglo de Oro y también de significativa importancia en el desarrollo de la narrativa posterior, tanto en España como en Hispanoamérica, por la gran influencia que ha tenido en numerosas obras. El mismo ha sido objeto de estudio de un gran número de hispanistas y motivo de numerosas controversias cuando se ha tratado de establecer sus características generales. Aunque el género de la novela picaresca clásica se considera cerrado, hay críticos que sugieren una serie de variantes al mismo para acomodar textos en los que se observan sus influencias. Entre estas variantes se encuentran las propuestas por Claudio Guillén: la novela picaresca en sentido lato y la novela picaresca en sentido mítico. Dentro de la crítica anglosajona existe una tendencia a estudiar la picaresca como una modalidad de las muchas que pueden darse en un texto determinado. Vista de esta manera, la picaresca se convierte en una tradición literaria que puede estar presente en cualquier obra.

A pesar de la existencia de la multiplicidad de visiones críticas con respecto a la obra, todas coinciden en señalar la presencia de un elemento unificador en todos los textos considerados picarescos: el pícaro, personaje protagónico, que ha sido objeto de estudio y caracterización de la crítica a través de los siglos, y cuya presencia se observa no solamente en relatos que cumplen con todos los rasgos del 
patrón clásico de la novela picaresca, sino también en obras que por su estructura o por su estilo no se ubican en la tradición iniciada en el Siglo de Oro. Este arquetipo surge en la literatura como consecuencia de unas condiciones económicas, políticas y sociales, existentes en un momento de transición, que condicionan e influyen su comportamiento antiheroico. Al intentar una redefinición del pícaro para proyectarlo fuera de su contexto de origen se llega a la conclusión de que el comportamiento picaresco es un modo de enfrentarse con la vida y está determinado por el entorno que rodea a cada personaje en particular. Su psicología se manifiesta, principalmente, mediante una actitud antiheroica y por un afán de subir en el esquema social, que en muchas ocasiones lo sitúa en la marginalidad.

En Cuba, el período histórico que se inicia en el año 1902 es de transición, puesto que se pasa del estado colonial a la república. Se dan en estos momentos las condiciones adecuadas para el surgimiento de una tipología de corte picaresco dentro de la sociedad cubana, caracterizada entonces por la inestabilidad económica, política y social. Sin embargo, la raíz de este fenómeno social se puede descubrir en algunos aspectos de la vida del país que se inician en la época colonial, y que son consecuencia de casi cuatrocientos años de dominación y vasallaje, de guerras y de treguas. 
La composición étnica del pueblo cubano es una de estas consecuencias. Debido al proceso de conquista y colonización, se hicieron presentes en la Isla diferentes grupos de europeos, mayormente de españoles, así como diversos grupos de africanos de variados orígenes, cada uno con sus rasgos psíquicos definitorios. Estas dos etnias son las que básicamente se combinaron para dar lugar a la población criolla. Esta población da muestra de una identidad nacional que surge a partir de los rasgos característicos del español y del negro, modificada por la influencia del medio ambiente, y que va evolucionando de acuerdo con los cambios que ocurren en el país hasta dar lugar a una psicología nacional cubana.

Durante el siglo XIX aparece, como parte de la sociedad cubana, una tipología en la que se ponen de manifiesto múltiples combinaciones de los rasgos heredados de los dos grupos étnicos que dieron lugar al estamento humano nacional. Dentro de esta tipología, se observan varios que presentan características que los relacionan psicológicamente con el pícaro clásico. Algunos de estos tipos desaparecieron definitivamente de la sociedad cubana republicana, mientras que otros se transformaron y su presencia se evidencia en la narrativa cubana posterior.

El pensamiento filosófico que se forjó en Cuba en los años previos a la instauración de la República y durante las primeras tres décadas de su existencia sirve de base para el planteamiento ulterior de los 
conflictos existentes en la sociedad y la resultante crítica social que llevan a cabo los narradores de la época. Este pensamiento fue, casi desde sus inicios, de índole anti-escolástica y agustiniana, y culmina con las corrientes positivistas iniciadas por Enrique José Varona. La educación del pueblo cubano era uno de los aspectos de mayor preocupación para el pensador, puesto que creía que la mayoría de los males y vicios de la sociedad de su tiempo eran el producto del atraso y la ignorancia en que se encontraba la población durante la colonia. Varona señaló abiertamente los males sociales imperantes en su época y que, según él, se originaron en la época colonial, y que provocaron las condiciones para el surgimiento de una tipología social de corte picaresco, como lo demuestran los textos narrativos de Jesús Castellanos, Miguel de Carrión y Carlos Loveira.

En comparación con otros géneros, la narrativa surge en Cuba de manera tardía. Los primeros textos narrativos aparecieron alrededor de 1834 y su aparición fue el resultado de un recrudecimiento de las tensiones entre el pueblo y el gobierno colonial y de mayores conflictos en el aspecto económico y social. Así, desde sus inicios, la narrativa cubana ha estado estrechamente vinculada al devenir histórico del país. Los narradores de cada período se han ocupado de reflejar en sus obras las transformaciones sociales y políticas que ocurrieron en su época. Por su parte, algunos historiadores de la literatura, como Raimundo Lazo, 
establecen un paralelo entre el proceso histórico y la producción literaria con el objeto de facilitar el estudio de la última.

La narrativa de fines del siglo XIX y de las primera tres décadas republicanas está enmarcada por dos hechos de capital importancia en la historia del país: la instauración de la República y el derrocamiento del régimen dictatorial del general Gerardo Machado. Influenciados estilísticamente por las corrientes europeas del realismo y el naturalismo, los narradores de esta época plasmaron en sus obras su preocupación fundamental, que era la situación crítica por la que atravesaba el país y los problemas de índole social y económica que afectaban a la población. Debido a estas condiciones, en las obras narrativas de la época se hace patente, en la mayoría de los casos, una acerba crítica social que se evidencia con la presentación de personajes-tipos, cuyo comportamiento picaresco se manifiesta como consecuencia inmediata a la necesidad de sobrevivir en una sociedad en estado de transición y en el que las instituciones sociales y políticas se encuentran seriamente deterioradas.

A pesar de que la crítica dedicada al estudio de la influencia del género picaresco en la narrativa hispanoamericana no hace referencia a ninguno de los narradores cubanos de esa época, ni a ninguna de las obras estudiadas en esta investigación, el análisis de las obras de tres escritores representativos de este período, Jesús Castellanos, Miguel de Carrión y Carlos Loveira, descubre la presencia de personajes que 
manifiestan un comportamiento de perfil picaresco con el fin manipular las estructuras del poder que limitan y condicionan las posibilidades de éxito, o en un intento de lograr sus objetivos en medio de un contexto socio-económico y político que se halla atravesando cambios significativos.

El estudio de la obra de Jesús Castellanos se basa en dos de sus novelas cortas: La Conjura (1908) y La manigua sentimental (1909). La investigación revela que en la primera novela, el autor presenta numerosos personajes que, independientemente del estrato social al cual pertenecen, muestran a través de la narración un comportamiento y una filosofía de vida que los acerca, definitivamente, al modelo del pícaro clásico. Algunos de los personajes, como es el caso del protagonista, Augusto Román, aparecen al principio como un héroe que trata de diferenciarse del resto de los individuos que lo rodean; sin embargo, al final, cede a las presiones del medio que lo fuerza a adoptar un comportamiento picaresco si quiere conseguir el éxito profesional. Otros personajes manifiestan, desde el inicio de la narración un comportamiento acomodaticio y pragmático que sugieren un perfil picaresco. Un tercer tipo de personaje que aparece en esta obra es el que representa a las esferas más altas de la sociedad. Este personaje ejerce el poder, y aunque no necesita recurrir al modo de vida picaresco para desenvolverse en la sociedad, sí predica la filosofía del pícaro y ejerce su 
influencia en otros personajes. Finalmente, Castellanos presenta a un personaje que no se comporta de modo picaresco, pero que acepta que para triunfar en esa sociedad es necesario actuar en consonancia con el modo picaresco.

En La manigua sentimental el protagonista se perfila, desde los inicios de la narración, como un personaje picaresco. Situado en un contexto heroico, como es la Guerra de Independencia de Cuba, la naturaleza antiheroica, picaresca, del personaje se hace más evidente. Lo que prevalece en la narración son las aventuras personales que manifiestan una actitud oportunista y acomodaticia y cuya participación en el proceso emancipador está motivado única y exclusivamente por un afán de lograr un lugar importante en el esquema social.

Los personajes de Jesús Castellanos se desenvuelven en una sociedad propicia para el surgimiento de tipos que, en su mayoría, carecen de espíritu de lucha y de rebeldía y presentan una actitud acomodaticia y falta de escrúpulos que los lleva a aprovecharse de las circunstancias imperantes para lograr mejorar sus condiciones de vida por cauces no convencionales.

El análisis de la obra de Miguel de Carrión está basado en el díptico conformado por Las honradas (1918) y Las impuras (1919). Ambas novelas tratan, básicamente, el mismo tema: la situación de la mujer en una sociedad cuyos cánones de decencia y falsa moral la 
obligan a adoptar un comportamiento picaresco como medio para evitar convertirse en víctima de una estructura del poder dominado por el hombre. La obra de Carrión, sirve pues, para conseguir una visión picaresca desde la perspectiva femenina.

El análisis de los personajes de Las honradas, a partir de una perspectiva de la picaresca revela que, en la mayoría de los casos, el comportamiento picaresco está en función de la satisfacción de los instintos sexuales, tanto en los personajes femeninos como en los masculinos, y es el resultado de un proceso educativo restrictivo para la mujer. El título de la obra es contradictorio, porque al concluir el análisis se pone de manifiesto que solamente aquellos personajes femeninos que, adoptando una filosofía picaresca con respecto a las relaciones sexuales, traspasaron los límites de la honradez, lograron su objetivo: ser verdaderamente felices en sus relaciones de pareja.

En Las impuras el autor presenta una serie de personajes cuyo modo de vivir picaresco está en consonancia con el mundo del hampa y la corrupción en el cual se desenvuelven. La excepción de esta afirmación es Teresa, la protagonista, que a pesar de que al inicio de la narración da la impresión de ser un personaje de filiación picaresco, se mantiene siempre fiel a sus valores morales.

Con el estudio de estas dos obras de Carrión se llega a la conclusión de que muchos de sus personajes, tanto femeninos como 
masculinos y pertenecientes a diferentes esferas sociales manifiestan un comportamiento de índole picaresca para hacerle frente a la moral imperante. En algunos de ellos se observa una metamorfosis gradual hacia el comportamiento picaresco, como lo ilustra Victoria en Las honradas; en otros, esa actitud está condicionada por las circunstancias de nacimiento y vida, como es el caso de Rigoletto de Las impuras. Un tercer tipo de personaje se vale del comportamiento picaresco como fórmula para lograr un objetivo. A diferencia de la picaresca renacentista y barroca, que presenta personajes cuyo objetivo primordial es ascender en la escala social o lograr una mejor posición económica, la novelística de Carrión se centra en personajes que, en su mayoría, lo que busca con el comportamiento picaresco es lograr un objetivo que está relacionado con el amor y el sexo.

La investigación de la narrativa de Carlos Loveira, toma como fuentes las novelas Generales y doctores (1920) y Juan Criollo (1928). La primera de las obras ofrece un panorama de la vida cubana durante los últimos años de dominación colonial y los primeros años de era republicana, donde se insertan una serie de personajes-tipos representativos de la sociedad de la época y que manifiestan un comportamiento que se relaciona con la tradición picaresca. Estos personajes son utilizados por el autor para denunciar la conducta de algunos individuos que se valían de un título universitario o de un rango 
militar, a veces obtenido inmerecidamente, para lograr el poder, tanto político, como económico y social. Esta conducta oportunista y carente de principios está de acuerdo con la psicología picaresca que manifiestan los tipos utilizados por Loveira con el fin de llevar a cabo una crítica de la sociedad.

El protagonista de Juan Criollo es, de todos los personajes analizados, el que más semejanzas presenta con el pícaro tradicional, puesto que su carácter picaresco no solamente viene dado por una conducta de marginalidad e ilegalidad en la edad adulta, sino también por su origen y condiciones de vida durante el período de la infancia. Las trayectorias de vida de Juan Cabrera y de Lazarillo de Tormes son paralelas en su naturaleza, con numerosos puntos convergentes, entre ellos su baja extracción social, su temprana orfandad, su vida itinerante y su acomodo social al llegar a la adultez.

Al finalizar la investigación se llega a la conclusión de que los tres autores estudiados presentan una visión de la realidad donde solamente los personajes que adoptan una filosofía picaresca de la vida son capaces de lograr el éxito. En los personajes de Castellanos la conducta picaresca es el instrumento para acceder a una posición social más elevada. Por su parte, los personajes de Carrión, adoptan el comportamiento picaresco en respuesta a una educación caracterizada por visiones falsas del amor y el sexo, y como una manera de lograr el éxito en sus relaciones sexuales; 
$y$ en el caso de los personajes femeninos como un medio de manipulación de la sociedad dominada por el poder masculino.

Finalmente, en los personajes de Loveira, el comportamiento picaresco es una consecuencia de las condiciones socio-económicas y políticas imperantes que niegan al individuo la posibilidad de éxito dentro de los cánones de la legalidad y lo fuerzan a buscar alternativas para asegurarse el poder político que es la única forma para alcanzar un nivel económico y social superior. 


\section{Bibliografía}

Abislaimán, Rafael B., ed. Félix Varela. Frases de Sabiduría. "Ideario". Miami: Ediciones Universal, 2000.

Aguilar, Luis E. Cuba 1933. Prologue to Revolution. New York: W. W. Norton and Company, Inc., 1974.

Allen, Walter. The English Novel. New York: Penguin Books, 1958.

Alvarado, Ana M. En torno a la cubanía: Aproximaciones a la idiosincrasia cubana. Miami: Ediciones Universal, 1999.

Alvarez, Imeldo. La novela cubana en el siglo XX. La Habana: Editorial Letras Cubanas, 1980.

Alzaga, Florinda. Raíces del alma cubana. Miami: Ediciones Universal, 1976.

Artalejo, Lucrecia. La máscara y el marañón. La identidad nacional cubana. Miami: Ediciones Universal, 1991.

Arroyo, Anita. José Antonio Saco: Su influencia en la cultura y en las ideas políticas de Cuba. Miami: Ediciones Universal, 1989.

Barrios, Manuel. La picaresca. Sevilla: Imprenta Andalucía, S. A., 1981.

Bataillon, Marcel. Picaros y picaresca. Madrid: Taurus, 1969.

Blasco Pascual, Francisco J. y María del Carmen González Marín. Ascética, mística y picaresca. Madrid: Editorial Cincel, S. A., 1992.

Bosch, Juan. Cuba, la isla fascinante. Santo Domingo: Editorial Alfa \& Omega, 1987.

Bueno, Salvador. Historia de la Literatura Cubana. La Habana: Editorial Nacional de Cuba, 1963.

Caballero, José Agustín. Escritos varios. La Habana: Editorial de la Universidad de La Habana, 1956.

Cabo Aseguinolaza, Fernando. El concepto de género y la literatura picaresca. Santiago de Compostela: Universidad de Santiago de Compostela, 1992. 
Cánepa, Mario A. "El 'pícaro' y la novela picaresca en Buenos Aires." Crítica Hispánica 16.2 (1994): 21 1-222.

Carrillo, Francisco. "Raiz sociológica e imaginación creadora en la picaresca española." La picaresca: Orígenes, textos y estructuras. Actas del Primer Congreso Internacional sobre la picaresca organizado por el Patronato "Arcipreste de Hita". Ed. Manuel Criado de Val. Madrid: Fundación Univ. Española, 1979. 65-77.

Carrión, Miguel de. El milagro y la esfinge. La Habana: Editorial Arte y Literatura, 1976.

---. Las honradas. La Habana: Editorial Letras Cubanas, 1981.

---. Las impuras. La Habana: Editorial Letras Cubanas, 1981.

Casas de Faunce, María. La novela picaresca latinoamericana. Madrid: Cupso Editorial, 1977.

Castellanos, Jesús. La conjura y otras narraciones. La Habana: Editorial Letras Cubana, 1978.

Castro, Américo. Hacia Cervantes. Madrid: Taurus, 1967.

Chain, Carlos. Formación de la nación cubana. La Habana: Ediciones Gramma, 1968.

Correa, Gustavo. "El héroe de la picaresca y su influecia en la novela moderna española e hispanoamericana." Thesaurus: Boletín del Instituto Caro y Cuervo: Muestra Antológica 1945-1985. Ed. Rubén Paez Patiño. Santa Fe de Bogotá: Instituto Caro y Cuervo, 1993. 713-732.

---."Galdós y la picaresca". Actas del Primer Congreso Internacional de Estudios Galdosianos. Madrid: Ediciones del Exmo. Cabildo Insular de Gran Canaria. 1977.

Costa, Octavio R. Imagen y Trayectoria del Cubano en la historia. 2 vols. Miami: Ediciones Universal, 1998.

Daghistany, Ann. "The pícara nature." Women Studies 5 (1977/1978): 51 60. 
De la Torriente, Loló. "Los caminos de la novela cubana." Cuadernos Americanos 67 (1953): 264-284.

Del Monte, Alberto. Itinerario de la novela picaresca. Barcelona: Lumen, 1971.

Duarte Oropesa, José. Historiología Cubana: Desde 1898 hasta 1944. Miami: Ediciones Universal, 1974.

Dunn, Peter N. Castillo Solórzano and the Decline of the Spanish Novel. Oxford: Basil and Blackwell, 1952.

---. Spanish Picaresque Fiction: A New Literary History. Ithaca y Londres: Cornell University Press, 1993.

---. The Spanish Picaresque Novel. Boston: Twayne, 1979.

Durán, Manuel. "La huella de la tradición picaresca en la narrativa española del siglo XIX." Studies in Honor of Gustavo Correa. Eds. Charles B. Faulhaber et al. Potomac, MD: Scripta Humanística, 1986. 73-91.

Earle, Peter G. "De Lazarillo a Eva Luna: Metamorfosis de la Picaresca." NRFH 36.2 (1988): 987-996.

Eoff, Sherman. "The Picaresque Psychology of Guzmán de Alfarache." Hispanic Review 21 (1953): 107-119.

Figueras, Francisco. Cuba y su evolución colonial. La Habana: Imprenta Avisador Comercial, 1907.

Friedman, Edward H. The Antiheroine's Voice. Columbia: University of Missouri Press, 1987.

Gay Galbó, Enrique. "Bibliografía de Generales y doctores." Cuba Contemporánea 26 (1921): 183-185.

Gómez Lance, Betty Rita. La actitud picaresca en la novela española del siglo XX. México: B. Costa-Amic, 1968.

González, Manuel Pedro. "Literatura y Realidad Cubana." Revista Bimestre Cubana. 34.2 (1934): 73-80. 
González, Mirza L. La novela y el cuento psicológicos de Miguel de Carrión. (Estudio Psico-social Cubano). Miami: Ediciones Universal, 1979.

Guillén, Claudio. "Toward a Definition of Picaresque." Literature as System: Essays Toward the Theory of Literary History. Princeton: Princeton UP, 1971. 71-106.

Guiral Moreno, Mario. "Aspectos censurables del cubano." Cuba Contemporánea. 4.2 (1914): 121-133.

Hanrahan, Thomas. La mujer en la picaresca española. Madrid: Ediciones José Porrúa Turanzas, 1967.

Henríquez Ureña, Max. Panorama histórico de la literatura cubana. 2 Vols. Puerto Rico: Ediciones Mirador, 1963.

Heras, Eduardo. "Prólogo". Las impuras. La Habana: Editorial Letras Cubanas, 198.

Hernández, José M. Félix Varela: El primer cubano. Miami: Cuban Studies Association, 1996.

Hernández Chiroldes, Alberto, ed. Los cubanos pintados por sí mismos. Edición Facsimilar. Miami: Editorial Cubana, 1992.

Ibarra, Jorge. Un análisis psicosocial del cubano: 1898-1925. La Habana: Editorial de Ciencias Sociales, 1995.

Izquierdo-Tejido, Pedro. El cuento cubano (Panorámica y antología). San José, Costa Rica: Litografía e Imprenta LIL, S.A., 1983.

Lazarillo de Tormes. Ed. Francisco Rico. Madrid: Ediciones Cátedra, S.A., 1994.

Lázaro Carreter, Fernando. "Para una revisión del concepto 'novela picaresca'." Actas del Tercer Congreso Internacional de Hispanistas. Eds. Carlos H. Magis et al. México: El Colegio de México por la Asociación de Hispanistas, 1970. 27-45.

Lazo, Raimundo. Historia de la literatura cubana. México: Universidad Nacional Autónoma de México, 1974. 
---.La literatura cubana. México: Universidad Nacional Autónoma de México, 1965.

Leal, Luis. "Picaresca hispanoamericana: De Oquendo a Lizardi." Estudios de literatura hispanoamericana en honor a José J. Arrom. Eds. Andrew Debicki et al. Chapel Hill: Department of Romance Languages, 1974. 47-58.

Lizaso, Félix. Panorama de la cultura cubana. México: Fondo de Cultura Económica, s.f.

Lope Blanch, Juan M. La novela picaresca. México D. F.: Universidad Nacional Autónoma de México, 1958.

López Segreara, Francisco. Cuba: Cultura y Sociedad (1511-1985). La Habana: Editorial Letras Cubanas, 1989.

Loveira, Carlos. Generales y doctores. New York: Oxford University Press, 1965.

---. Juan Criollo. New York: Las Americas Publishing Co., 1964.

Mañach, Jorge. La crisis de la alta cultura en Cuba. Indagación del choteo. Ed. Rosario Rexach. Miami: Ediciones Universal, 1991.

Maravall, José Antonio. "La aspiración social de 'medro' en la novela picaresca." Cuadernos Hispanoamericanos: Revista Mensual de Cultura 312 (1976): 590-625.

---. La literatura picaresca desde la historia social. Madrid: Taurus Ediciones, S. A., 1986.

---. "Pobres y pobreza del medioevo a la primera modernidad: Para un estudio histórico-social de la picaresca." Cuadernos Hispanoamericanos: Revista Mensual de Cultura Hispánica 367-368 (1981): 189-242.

Marqués, Sarah. Arte y sociedad en las novelas de Carlos Loveira. Miami: Ediciones Universal, 1977.

Márquez Sterling, Carlos y Manuel. Historia de la Isla de Cuba. Miami: Books \& Mas, Inc. 1996. 
Márquez, Sterling, Manuel. Alrededor de nuestra psicología. La Habana: Imprenta Avisador Comercial, 1906.

Martínez, Miguel A. "Personajes secundarios en las novelas de Carlos Loveira." Hispania 56.1 (1973) 1030-1039.

Masó y Vázquez, Calixto. El carácter del cubano: Apuntes para un ensayo de Psicología Social. Miami: Ediciones Universal, 1996.

---. Historia de Cuba. Miami: Ediciones Universal, 1998.

Menocal y Cueto, Raimundo. Origen y desarrollo del pensamiento cubano. 2 Vols. La Habana: Editorial Lex, 1945.

Miller, Stuart. The Picaresque Novel. Cleveland: The Press of Case Western Reserve University, 1967.

Molho, Maurice. Introducción al pensamiento picaresco. Salamanca: Anaya, 1972.

Ortiz, Fernando. Entre cubanos: Psicología tropical. La Habana: Editorial de Ciencias Sociales, 1987.

--.."La decadencia cubana". Orbita de Fernando Ortiz. Ed. Julio Le Riverend. La Habana: Unión de Escritores y Artistas de Cuba, 1973. 69-80.

---. Los negros esclavos. La Habana: Editorial de Ciencias Sociales, 1975.

Parker, Alexander A. Los pícaros en la literatura. La novela picaresca en España y Europa (1599-1753). Madrid: Editorial Gredos, S. A., 1971.

Pereda Valdés, Ildefonso. La novela picaresca y el pícaro en España y América. Montevideo: Organización Medina, 1950.

Pérez Galdós, Benito. Obras completas. Madrid: Aguilar, 1951.

Pogolotti, Marcelo. La República de Cuba al través de sus escritores. La Habana: Editorial Lex, 1958.

Portell Vilá, Herminio. Nueva historia de la República de Cuba. Miami: La Moderna Poesía, Inc., 1996. 
Portuondo, José Antonio. Bosquejo Histórico de las Letras Cubanas. La Habana: Ministerio de Relaciones Exteriores, 1961.

---. "El rasgo predominante de la novela hispanoamericana." La novela iberoamericana. Memoria del Quinto Congreso del Instituto Interna de Literatura Iberoamericana. Albuquerque, 1951.

Praag, J. A. van. "La pícara en la literatura española." Spanish Review 3 (1936): 63-74.

Rasco, José Ignacio. Hispanidad y cubanidad. Miami: Ediciones Universal, 1987.

Remos, Juan J. Historia de la literatura cubana 3 Vols. Miami: Mnemosyne Publishing Co. Inc., 1969.

---. Los forjadores de la cultura cubana. Ediciones del Directorio Magisterial Cubano (exilio), 1966.

Rexach, Rosario. "El hombre nuevo en la novela picaresca española." Cuadernos Hispanoamericanos: Revista Mensual de Cultura Hispánica 275 (1973): 367-377.

Rey Hazas, Antonio. La novela picaresca. Madrid: Grupo Anaya, S. A., 1990.

---, ed. Picaresca femenina. Barcelona: Plaza \& Janes Editores, S. A., 1986.

---. "Poética comprometida de la 'novela picaresca'." Nuevo Hispanismo 1 (1982): 55-76.

Rodríguez, José I. Vida del presbítero don Félix Varela. La Habana: Arellano y Cía, 1944.

Rodríguez-Luis, Julio. "Pícaras: The Modal Approach To the Picaresque." Comparative Literature 31 (1979): 32-46.

Roig de Leuchsenring, Enrique. Facetas de la vida de Cuba Republicana, 1902-1952. La Habana: Oficina del Historiador de la Ciudad, 1954.

Ronquillo, Pablo Javier. Retrato de la pícara: La protagonista de la picaresca española del XVII. Madrid: Editorial Playor, 1980. 
Ruiz Morcuende, Federico. La novela picaresca. Madrid: Instituto-Escuela, 1935.

Salillas, Rafael. El delincuente español: Hampa (antropología picaresca). Madrid: Librería de Victoriano Suárez, 1898.

Sánchez, Francisco J. y Nicholas Spadaccini. "La picaresca desde el pensamiento de Maravall." Ideologies and Literature: Journal of Hispanic and Lusophone Discourse Analysis 3.1 (1988): 7-33.

Sánchez, Reinaldo. “'Don Junípero': Vehículo del costumbrismo en Cuba." Revista Iberoamericana. 152-153 (1990): 759-768.

Sánchez Boudy, José. Enrique José Varona y Cuba. Miami: Ediciones Universal, 1990.

Serpa, Gustavo. Apuntes sobre la filosofía de Varela. La Habana: Editorial de Ciencias Sociales, 1983.

Shelton, Raúl M. Cuba y su cultura. Miami: Ediciones Universal, 1993.

Souiller, Didier. La novela picaresca. México D. F.: Fondo de Cultura Económica, 1985.

Tejera, Diego Vicente. "La indolencia cubana." Cuba Contemporánea 28 (1922): 169-177.

---. "La sociedad cubana". Revista Bimestre Cubana 44 (1939): 365-375. 2.

Toledo Sande, Luis. "Prólogo". La conjura y otras narraciones. La Habana: Editorial Letras Cubanas, 1978.

---. "Prólogo". Las honradas. La Habana: Editorial Letras Cubanas, 1981.

Valdés, Berardo. Panorama del cuento cubano. Miami: Ediciones Universal, 1976.

Vitier, Medardo. Las ideas y la filosofía en Cuba. La Habana: Editorial de Ciencias Sociales, 1970.

---. La lección de Varona. México, D.F.: El Colegio de México, 1945.

Wicks, Ulrich. "The Nature of Picaresque Narrative: A Modal Approach." PMLA 89 (1974): 240-248. 
---. Picaresque Narrative. Picaresque Fictions: Theory and Research Guide. New York: Greenwood Press, 1989.

Yáñez, Agustín. "El Pensador Mexicano". Fichas mexicanas. México: El Colegio de México, 1945. 60-94.

Zamora Vicente, Alonso. ¿Qué es la novela picaresca? Buenos Aires: Editorial Columba, 1962.

Zayas, Alfredo, ed. Obras de don José de la Luz y Caballero. La Habana: La Propaganda Literaria, 1890. 
VITA

\section{GISELA BENCOMO}

1979

BA Spanish

Florida International University

Miami, Florida

1979

BA Chemistry

Florida International University

Miami, Florida

1981

MS Modern Language Education

Florida International University

Miami, Florida

1985-present

Spanish Teacher

Miami Dade County Public Schools

1993

Summer Course for Hispanic Professors Universidad de Alcalá de Henares

Alcalá de Henares, Spain

$1995-2000$

Member of the Advanced Placement Spanish

Developing Committee

$1999-2003$

Doctoral Candidate in Spanish

Florida International University

Miami, Florida

\section{PUBLICATIONS AND PRESENTATIONS}

Bencomo, Gisela. "Acercamiento a los géneros en prosa. El caso de la narrativa". Teacher's Guide: Advanced Placement Spanish Literature. New York: The College Entrance Examination Board, 2001.

Bencomo, Gisela. Cliffs AP Spanish Language. New York: Wiley Publishing, Inc., 2002. 
Bencomo, Gisela."Historia y ficción en Vía Crucis de Emilio Bacardí". Nation, Culture and Identity. Conference on Iberian and Iberian America Literatures. Florida International University/ University of Miami. Miami, Florida. October, 1997.

Bencomo, Gisela. Primary Editor, Teacher's Guide: Advanced Placement Spanish Language. New York: The College Entrance Examination Board and Educational Testing Services, 1998.

Bencomo, Gisela. "Uso de la lectura como base para la escritura". American Association of Teachers of Spanish and Portuguese Annual Convention. San Juan, Puerto Rico, 2000. 